
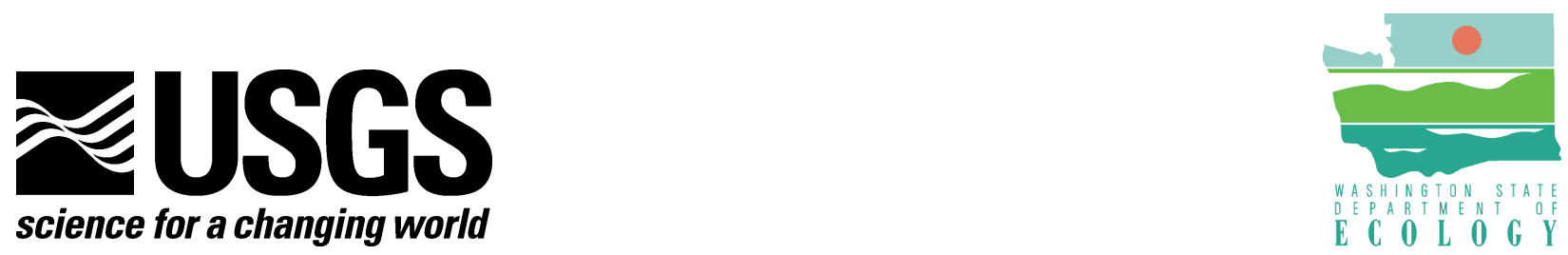

Prepared in Cooperation with the Washington State Department of Ecology

\title{
Beach Morphology Monitoring in the Columbia River Littoral Cell: 1997-2005
}

By Peter Ruggiero', Jodi L. Eshleman², Etienne Kingsley', David M. Thompson³, Brian Voigt", George M. Kaminsky ${ }^{5}$, and Guy Gelfenbaum'

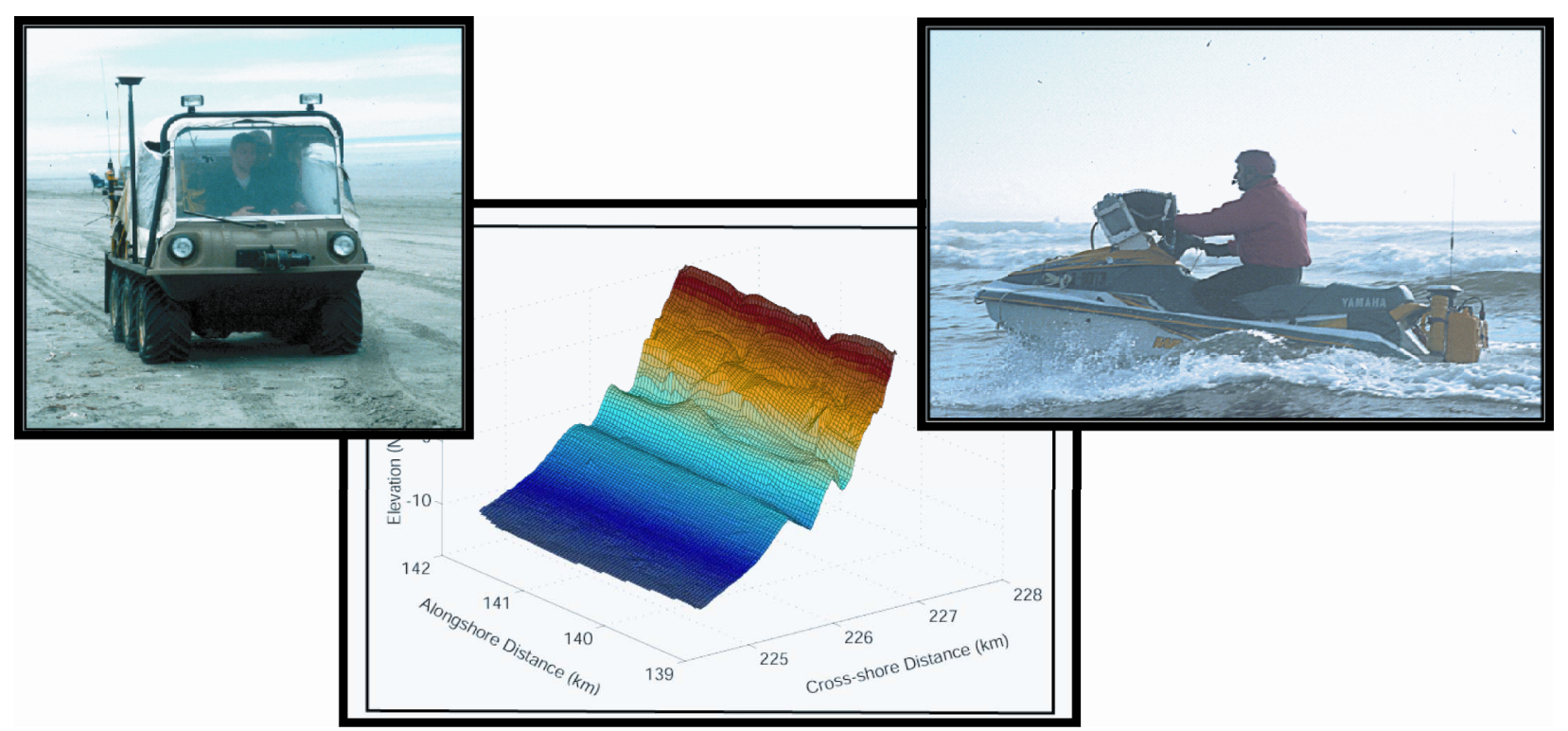

Data Series 260

2007

US Department of the Interior

US Geological Survey

${ }^{1}$ US Geological Survey, Menlo Park, CA

${ }^{2}$ US Geological Survey, Santa Cruz, CA

${ }^{3}$ US Geological Survey, St. Petersburg, FL

${ }^{4}$ University of Vermont, Burlington, VT

${ }^{5}$ WA Department of Ecology, Olympia, WA 


\title{
U.S. Department of the Interior DIRK KEMPTHORNE, Secretary
}

\author{
U.S. Geological Survey \\ Mark D. Myers, Director
}

U.S. Geological Survey, Reston, Virginia 2007

For product and ordering information:

World Wide Web: http://www.usgs.gov/pubprod

Telephone: 1-888-ASK-USGS

For more information on the USGS - the Federal source for science about the Earth, its natural and living resources, natural hazards, and the environment:

World Wide Web: http://www.usgs.gov

Telephone: 1-888-ASK-USGS

Suggested citation:

Ruggiero, Peter, Eshleman, Jodi L., Kingsley, Etienne, Thompson, David M., Voigt, Brian, Kaminsky, George M., and Gelfenbaum, Guy, 2007, Beach morphology monitoring in the Columbia River littoral cell: 1997-2005Report: U.S. Geological Survey Data Series 260 [http://pubs.usgs.gov/ds/2007/260/ ].

Any use of trade, product, or firm names is for descriptive purposes only and does not imply endorsement by the U.S. Government. 


\section{SUMMARY}

This report describes methods used, data collected, and results of the Beach Morphology Monitoring Program in the Columbia River Littoral Cell (CRLC) from 1997 to 2005. A collaborative group primarily consisting of the US Geological Survey and the Washington State Department of Ecology performed this work. Beach Monitoring efforts consisted of collecting topographic and bathymetric horizontal and vertical position data using a Real Time Kinematic Differential Global Positioning System (RTK-DGPS). Sediment size distribution data was also collected as part of this effort. The monitoring program was designed to: 1) quantify the short- to medium-term (seasonal to interannual) beach change rates and morphological variability along the CRLC and assess the processes responsible for these changes; 2) collect beach state data (i.e., grain size, beach slope, and dune/sandbar height/position) to enhance the conceptual understanding of CRLC functioning and refine predictions of future coastal change and hazards; 3) compare and contrast the scales of environmental forcing and beach morphodynamics in the CRLC to other coastlines of the world; and 4) provide beach change data in a useful format to land use managers. 


\section{CONTENTS}

SUMMARY .... -

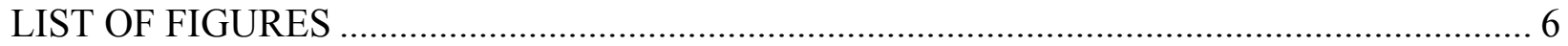

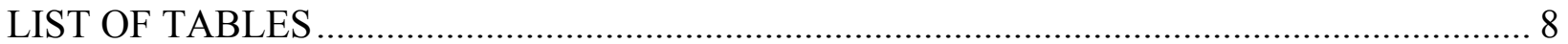

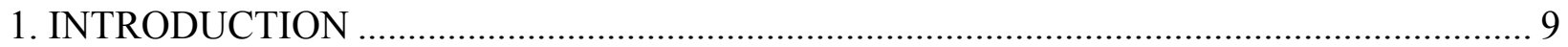

1.1 Southwest Washington Coastal Erosion Study ………................................................. 9

1.2 Beach Morphology Monitoring Program........................................................................ 10

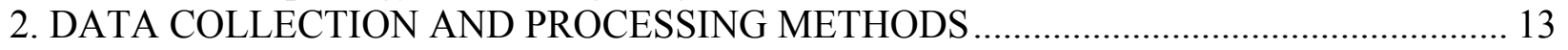

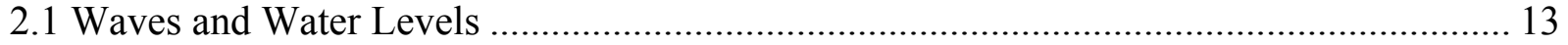

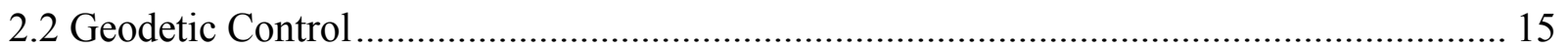

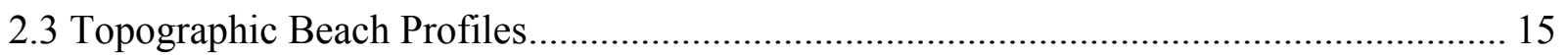

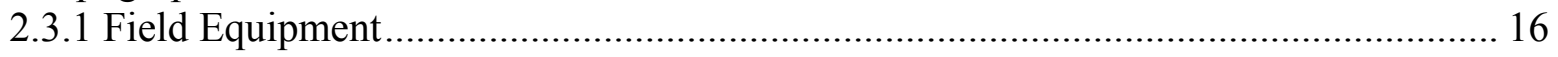

2.3.2 Field Procedures.............................................................................................. 17

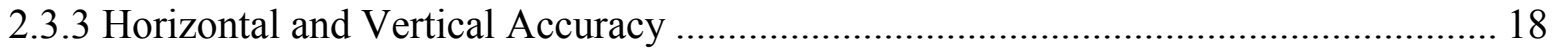

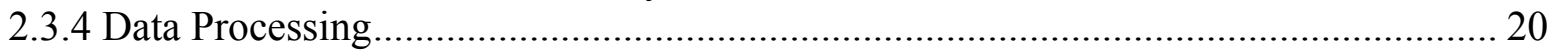

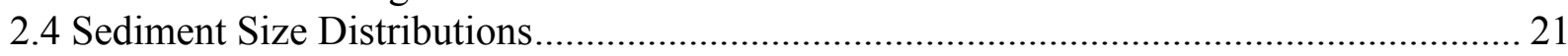

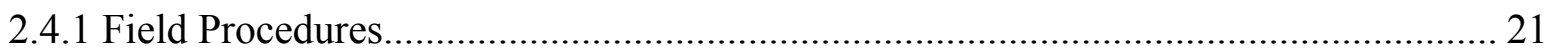

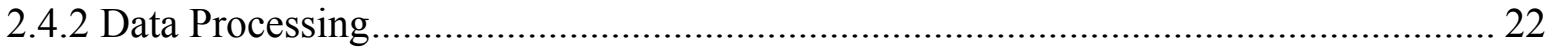

2.5 Topographic 3-D Beach Surface Maps........................................................................ 22

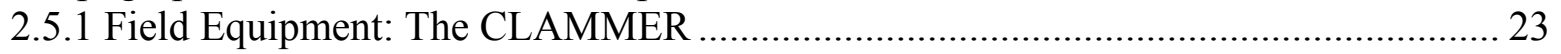

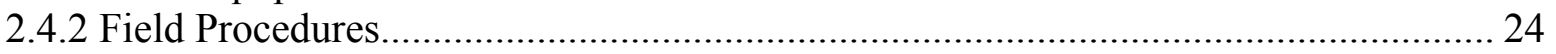

2.4.3 Horizontal and Vertical Accuracy ........................................................................ 24

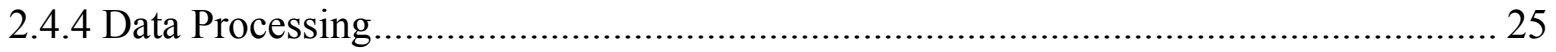

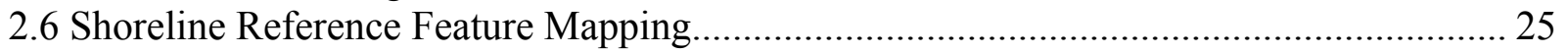

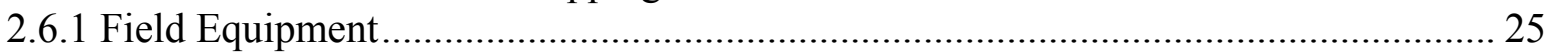

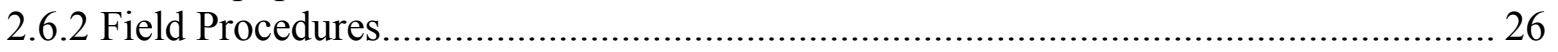

2.6.3 Horizontal and Vertical Accuracy …………………............................................... 26

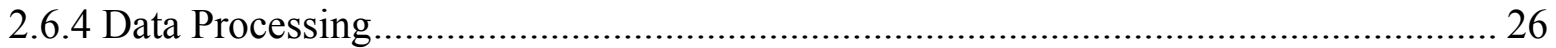

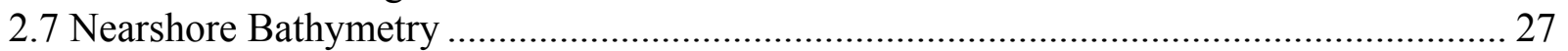

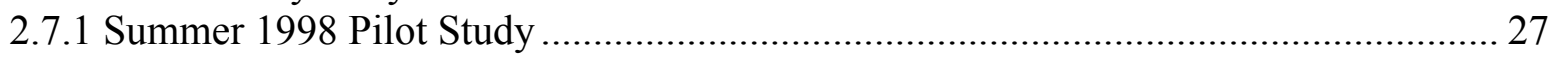

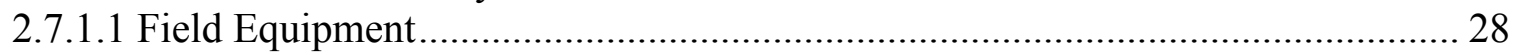

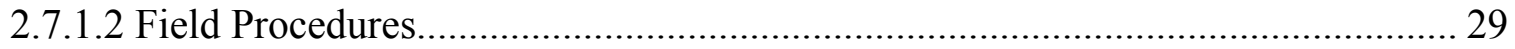

2.7.1.3 Horizontal and Vertical Accuracy ................................................................... 30

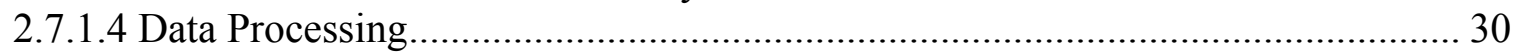

2.7.2 Regional nearshore monitoring, 1999-2003 ............................................................ 32

2.7.2.1 Field Equipment: Second Generation Coastal Profiling System ........................... 33

2.7.2.2 Field Procedures............................................................................................ 35

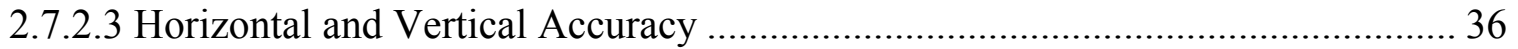

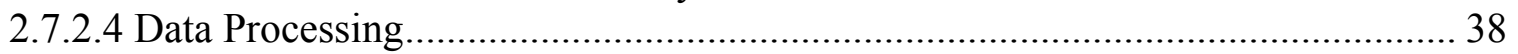

2.7.3 Regional nearshore monitoring, 2004-present .......................................................... 40

2.7.3.1 Field Equipment: Third Generation Coastal Profiling System .............................. 41

2.7.3.2 Field Procedures....................................................................................... 42

2.7.3.3 Horizontal and Vertical Accuracy ................................................................... 42

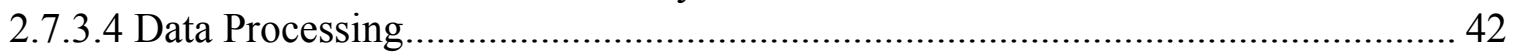




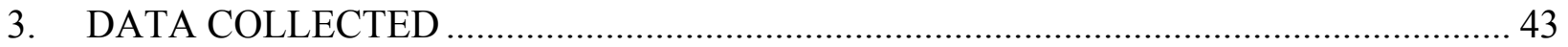

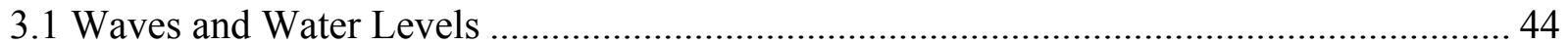

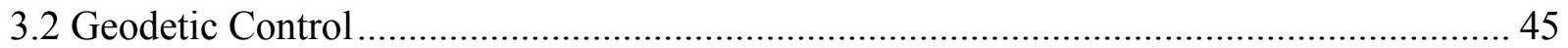

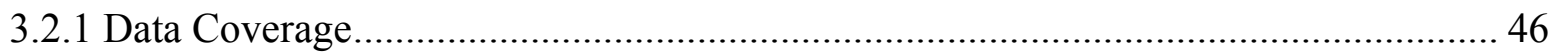

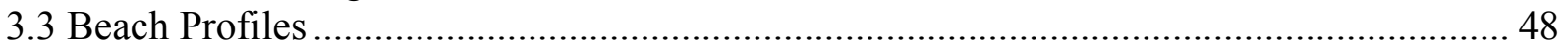

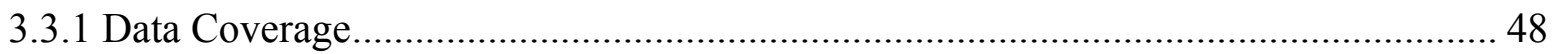

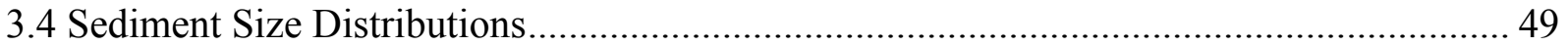

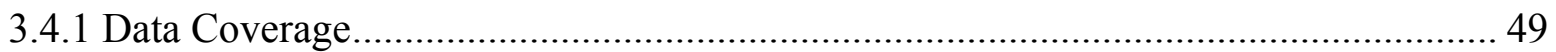

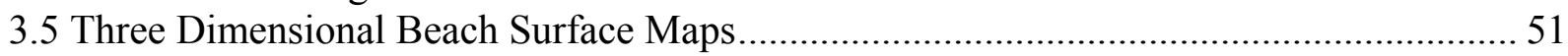

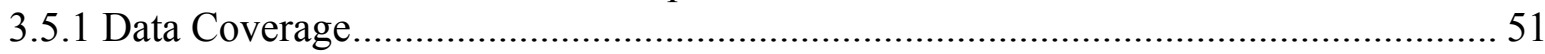

3.6 Shoreline Reference Feature Mapping ……………..................................................... 52

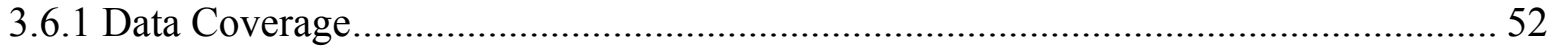

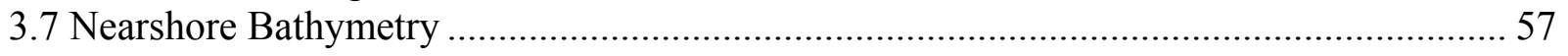

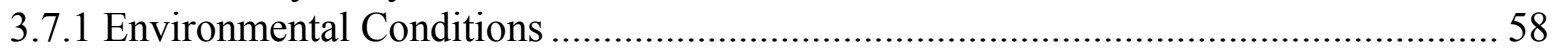

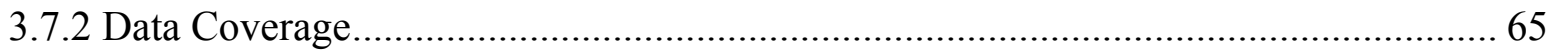

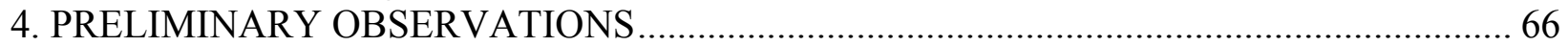

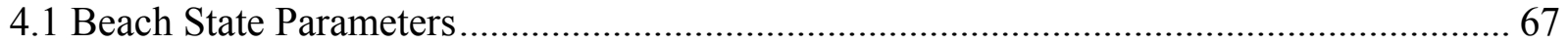

4.2 Seasonal to Interannual Beach Change........................................................................ 71

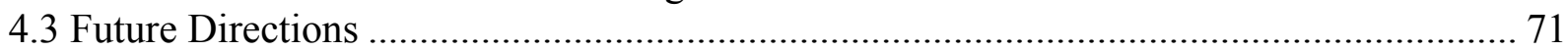

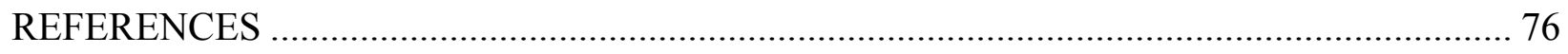

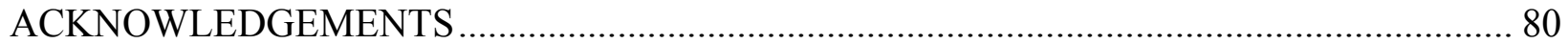

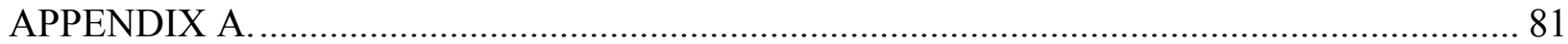

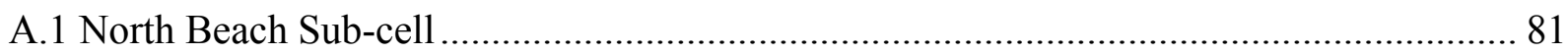

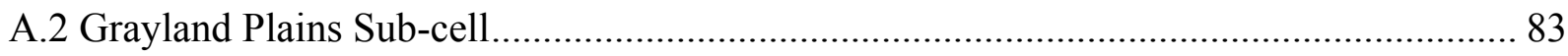

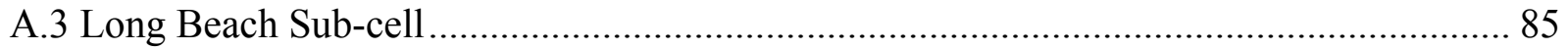

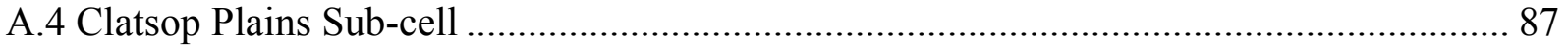




\section{LIST OF FIGURES}

Figure 1. The Columbia River Littoral Cell stretches approximately 165 kilometers between Tillamook Head, Oregon and Point Grenville, Washington. The littoral cell is divided into four sub-cells, including the Clatsop Plains, Long Beach, Grayland Plains and North Beach. The sub-cells are separated by estuary entrances at the Columbia River, Willapa Bay and Grays Harbor and are bounded by rocky headlands at the northern and southern extents... 12 Figure 2. Beach profiles are monitored at 47 sites throughout the littoral cell. Three-dimensional surface maps are collected at 16 sites. Nearshore bathymetry is collected annually along more than half of the littoral cell, nominally at kilometer-spaced transects and in more detail at selected surface map sites. The locations of long-term tide and wave gages are also shown.

Figure 3. Example setup of GPS equipment. The disc antenna on the tripod (left) receives data from satellites while the antenna on the right transmits this information to a rover receiver collecting data on the beach.

Figure 4. Real Time Kinematic Differential Global Positioning System surveying techniques used in the beach morphology monitoring program. a) Cross-shore topographic beach profiles are collected with a rover receiver, an antenna attached to a backpack, and a handheld data logger, b) three-dimensional topographic surface maps are collected with the Coastal All-terrain Morphology Monitoring and Erosion Research Vehicle (CLAMMER), and c) nearshore bathymetry is collected with a Coastal Profiling System....................... 18

Figure 5. Repeatability of the cross-shore beach profile methodology. The top panel shows a section of a beach profile as measured by three GPS operators. The bottom panel features the elevation difference between the subsequent profiles indicating the resolution of the

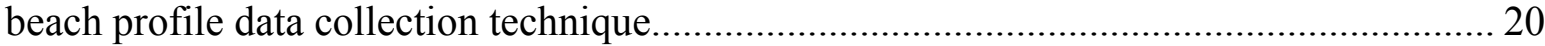

Figure 6. Original Coastal Profiling System (CPSI) being launched. ...................................... 28

Figure 7. The Coastal Profiling System records vertical elevations relative to a land based vertical datum in meters. The vertical component of bathymetry combines several variables

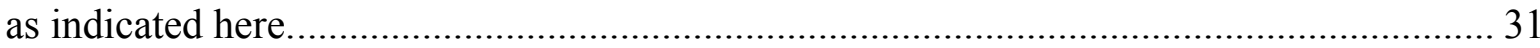

Figure 8. Second generation Coastal Profiling System (CPSII) in dry dock............................ 33

Figure 9. Repeatability comparison between a (smoothed) cross-shore profile surveyed with two

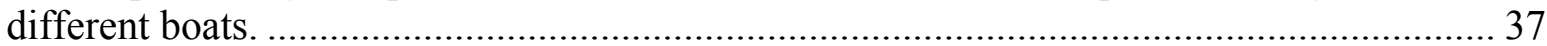

Figure 10. Merge between bathymetric and topographic data collected along a profile............. 38

Figure 11. Third generation Coastal Profiling System (CPSIII) in action.................................. 41

Figure 12. Monthly means a) water levels measured at the NOS Toke Point tide gage in Willapa Bay, b) significant wave height, c) period, and d) direction from the Grays Harbor CDIP buoy. The solid line represents long-term means beginning in 1980 for water levels, 1981 for wave heights and periods and 1993 for wave direction. The 1997/1998 El Niño (dash line) and the 1998/1999 La Niña (short dashed) are also shown.

Figure 13. Seasonal changes a) observed along a cross-shore beach profile and, b) in a datumbased extracted shoreline in the CRLC.

Figure 14. Surface map data is used to a) generate contour maps, b) extract contour locations, c) and compare contour change over time, d) by creating a 2-dimensional gridded surface from raw data points.

Figure 15. Shoreline reference features mapped at Ocean Shores, WA from 1997-2001.......... 53

Figure 16. Shoreline reference features mapped at Westport, WA from 1997-2003 ................. 54

Figure 17. Shoreline reference features mapped at Cape Shoalwater, WA from 1997-2001...... 55 
Figure 18. Shoreline reference features mapped at Ft Canby, WA from 1997-2004................ 56

Figure 19. Shoreline reference features mapped at Clatsop, OR from 1997-2000.................... 57

Figure 20. Nearshore bathymetry profiles collected from 1998-2001 in each of the four sub cells.

Figure 21. Nearshore bathymetry profiles collected from 2002-2005 in each of the four sub cells.

Figure 22. Beach state parameters along the CRLC. a) The average median grain size from samples collected at approximately MHW during both the summer 1998 and summer 1999 survey are shown. b) The slope of the sub-aerial beach as defined as the gradient between the 1.0 and $3.0 \mathrm{~m}$ elevation contours on the profile. Slope values have been averaged for 6 summer surveys collected between 1997 and 2002 at each of the 47 beach profile locations. c) The primary dune crest elevation, as measured in summer 1997, is given relative to NAVD 88.

Figure 23. Bathymetric beach state parameters (summer 2002). a) A regional inventory of nearshore beach slope represented by the water depth $1500 \mathrm{~m}$ from the $3.0 \mathrm{~m}$ contour, $\mathrm{b}$ ) the position of sandbar (outer and inner) crests, c) sandbar crest depths, and d) sandbar heights. The plusses on the map of the littoral cell indicate where nearshore beach profiles are collected.

Figure 24. Seasonal- interannual shoreline (contour) variability. The average winter erosion and average summer progradation of the $3.0 \mathrm{~m}$ contour line derived from 15 of the 16 beach surface maps between 1997 and 2005. These large seasonal fluctuations produce low net annual shoreline change rates. Recent interannual shoreline change rates are similar to decadal-scale shoreline change observed between 1974 and 1999 (Kaminsky et al., 1999).72

Figure 25. Interannual shoreline change rate determined from sub-aerial topographic beach profiles collected from 1997-2005. 


\section{LIST OF TABLES}

Table 1. Description of wave buoys and tide gages currently operating within the Columbia

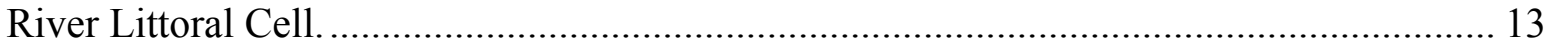

Table 2. Name and location for each of the 49 beach profiles. ................................................ 15

Table 3. Name and bounding coordinates for each of the 16 beach surface maps........................ 23

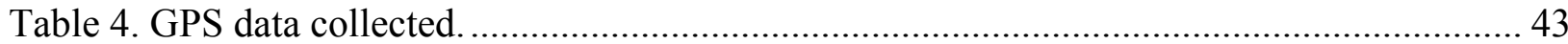

Table 5. Coordinates for the stations contained within the Washington Coastal Geodetic Control Network in the Washington State Plane, South, meters, NAD 83 and NAVD 88 coordinate

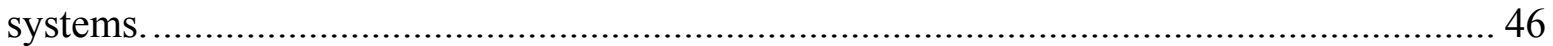

Table 6. Coordinates for sediments surface sample locations. .................................................. 50

Table 7. Shoreline Reference Feature Positions ………………………………………............. 52

Table 8. List of bathymetric profiles collected by subcell and environmental conditions in 1998

Table 9. List of bathymetric profiles collected by subcell and environmental conditions in 1999

Table 10. List of bathymetric profiles collected by subcell and environmental conditions in 2000

Table 11. List of bathymetric profiles collected by subcell and environmental conditions in 2001

Table 12. List of bathymetric profiles collected by subcell and environmental conditions in 2002

Table 13. List of bathymetric profiles collected by subcell and environmental conditions in 2003

Table 14. List of bathymetric profiles collected by subcell and environmental conditions in 2004

Table 15. List of bathymetric profiles collected by subcell and environmental conditions in 2005

Table 16. Beach profile name, location, 3.0-m contour change rate, beach slope and sediment size.

Table 17. Alongshore averaged change rates of the $3.0 \mathrm{~m}$ contour calculated for each of the 16 topographic beach surface maps. 


\section{INTRODUCTION}

\subsection{Southwest Washington Coastal Erosion Study}

The Southwest Washington Coastal Erosion Study (SWCES) is a multidisciplinary investigation of the Columbia River Littoral Cell (CRLC, Figure 1). The study, initiated in 1996, is cosponsored by the US Geological Survey and the Washington State Department of Ecology. The primary goals of the study are to improve scientific understanding of coastal morphodynamics and sedimentary processes, to determine natural and anthropogenic influences on the littoral system, and to provide information and predictions of coastal behavior at temporal and spatial scales of decades and tens of kilometers, respectively (Kaminsky et al., 1997; Gelfenbaum et al., 1997; Kaminsky et al., 1999; Ruggiero et al., 2005).

The Columbia River littoral cell extends approximately $165 \mathrm{~km}$ between Tillamook Head, OR and Point Grenville, WA and consists of four concave-shaped prograded barrier plain sub-cells separated by estuary entrances of the Columbia River, Willapa Bay, and Grays Harbor (Figure 1). Wide, gently sloping beaches characterize the region with sands having been derived from the Columbia River, the third largest river in the United States by discharge. Broad surf zones with multiple sandbars characterize the fully dissipative (Wright and Short, 1983), infragravity energy dominated nearshore zone of the CRLC. The beaches are backed predominantly by prograded dune fields and swales and by seacliffs along the northern half of the North Beach sub-cell (Figure 1). The prograded barrier beaches along this tectonically active coastal margin have experienced episodic erosion (Meyers et al., 1996) and sudden 1 to $2 \mathrm{~m}$ subsidence events associated with large earthquakes of approximately 500 year recurrence intervals (Atwater et al., 1995), the last such event occurring in 1700. Anthropogenic influences, including jetty construction in the late 1800s and early 1900s at the entrances to the Columbia River and Grays Harbor (Kaminsky et al., 1999; Gelfenbaum et al., 2001; Buijsman et al., 2003) and dam construction on the Columbia River during the $20^{\text {th }}$ century (Gelfenbaum et al., 1999), resulted in significant impacts to the natural sedimentary dynamics of the CRLC coastal system. 


\subsection{Beach Morphology Monitoring Program}

A beach morphology monitoring program was initiated in the CRLC during the summer of 1997 as one component of the SWCES (Ruggiero et al., 1998; Kaminsky et al., 1998; Ruggiero et al., 1999; Ruggiero and Voigt, 2000; Ruggiero et al., 2005). The field program is designed to document the short- to medium-term morphological variability of the high-energy dissipative beaches within the littoral cell over spatial scales ranging from meters to kilometers in the crossshore and tens of meters to kilometers in the alongshore. Following the installation of a dense network of geodetic control monuments (Daniels et al., 1999), a nested sampling scheme consisting of cross-shore topographic beach profiles, 3-dimensional topographic beach surface maps, shoreline change reference feature surveys, sediment size distributions, nearshore bathymetry, and site specific special projects was initiated. Monitoring is being conducted using Real Time Kinematic Differential Global Position System (RTK DGPS) survey methods that combine both high accuracy and speed of measurement (Morton et al., 1993).

The primary objectives of the monitoring program are to:

1) Quantify the short- to medium-term (seasonal to interannual) beach change rates and morphological variability along the CRLC and assess the processes responsible for beach change at these and other scales;

2) Collect beach state data (i.e., grain size, beach slope, and dune/sandbar height/position) to enhance the conceptual understanding of CRLC functioning and refine predictions of future coastal change and hazards;

3) Compare and contrast the scales of environmental forcing and beach morphodynamics in the CRLC to other coastlines of the world;

4) Provide beach change data in an appropriate format to land use managers.

Components of the monitoring program include:

- data retrieval from wave and water level gages

- geodetic control 
- topographic beach profiles and surface maps

- $\quad$ sediment size distributions

- shoreline reference feature mapping, and

- nearshore bathymetry

The data from the monitoring program are being integrated with other data sets, including those that document the long-term coastal evolution and geological framework of the CRLC, to develop conceptual and predictive models of coastal evolution at scales relevant to coastal planning and decision-making (Kaminsky et al., 1999; Kaminsky et al., 2001; Buijsman et al., 2001, Ruggiero et al., in press). This report describes the techniques used in the monitoring program, the data sets collected, and some initial results serving as an update to the beach monitoring report published by Ruggiero and Voigt in 2000. This report is only available in digital format and is accompanied by links to data files and associated metadata. 


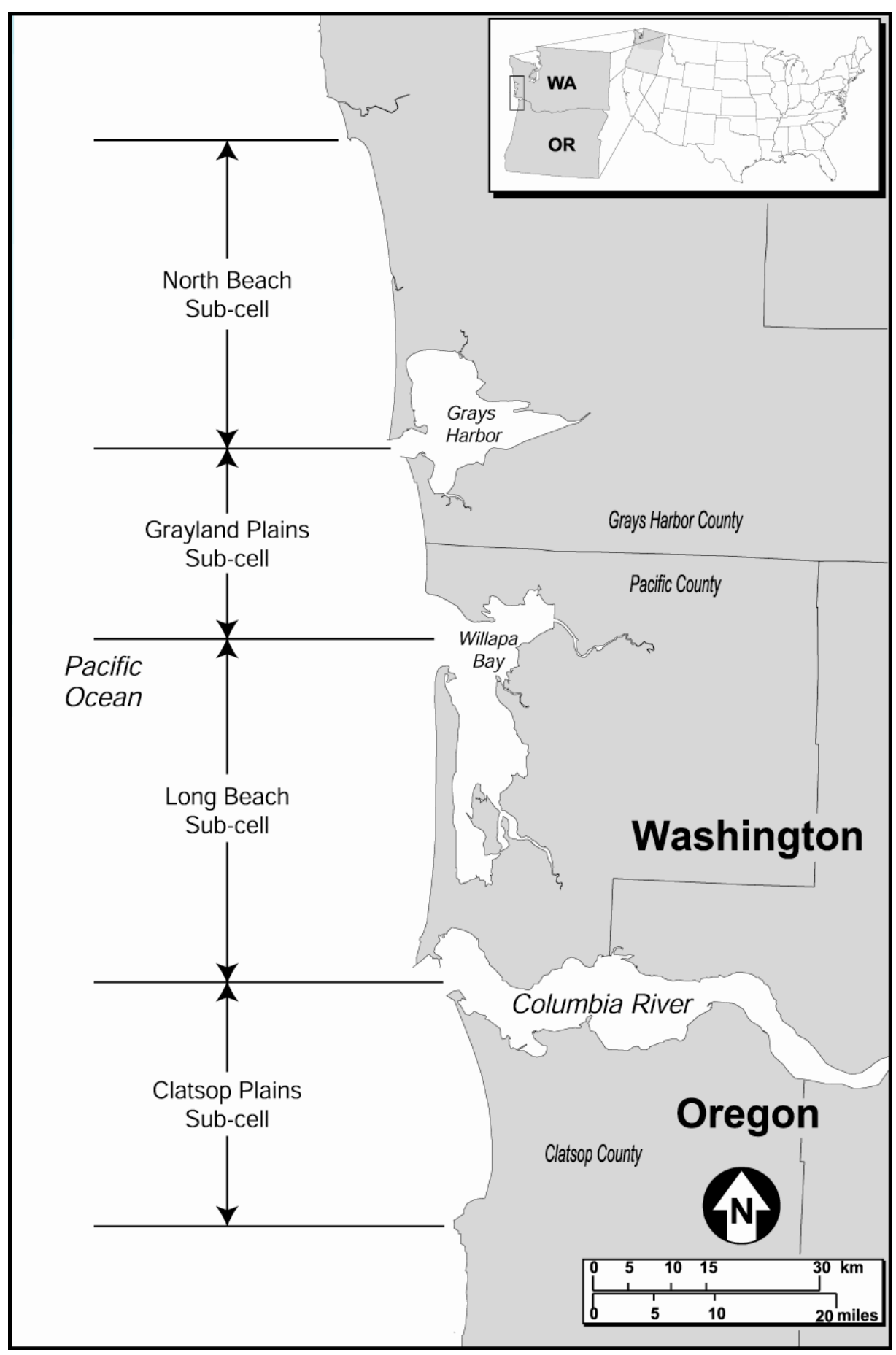

Figure 1. The Columbia River Littoral Cell stretches approximately 165 kilometers between Tillamook Head, Oregon and Point Grenville, Washington. The littoral cell is divided into four sub-cells, including the Clatsop Plains, Long Beach, Grayland Plains and North Beach. The subcells are separated by estuary entrances at the Columbia River, Willapa Bay and Grays Harbor and are bounded by rocky headlands at the northern and southern extents. 


\section{DATA COLLECTION AND PROCESSING METHODS}

\subsection{Waves and Water Levels}

Maintaining a database of the environmental forcings responsible for beach change and variability is critical for modeling future shoreline positions and quantifying the probability of coastal flooding. Fortunately there are national networks of both wave and water level gages (Table 1) maintained by various federal agencies (e.g., the Coastal Data Information Program (CDIP), the National Data Buoy Center (NDBC), and the National Ocean Service (NOS)) that make data available via the internet (http://cdip.ucsd.edu/;

http://www.ndbc.noaa.gov/index.shtml;

http://tidesandcurrents.noaa.gov/station_retrieve.shtml?type=Tide\%20Data\&sort=A.STATION_ ID\&state $=\& i d 1=)$. At present, there are three wave buoys and two tide gages operating in the CRLC (Figure 2).

Table 1. Description of wave buoys and tide gages currently operating within the Columbia River Littoral Cell.

\begin{tabular}{|c|c|c|c|c|}
\hline Type & Station Name & Location & $\begin{array}{c}\text { Water } \\
\text { Depth (m) }\end{array}$ & $\begin{array}{l}\text { Period of } \\
\text { Operation }\end{array}$ \\
\hline Waves & NDBC-46029 & Lat. $42^{\circ} 07^{\prime} 00^{\prime \prime} \mathrm{N}$; Long. $124^{\circ} 30^{\prime} 00^{\prime \prime} \mathrm{W}$ & 128 & 1984-present \\
\hline Waves & CDIP-036 & Lat. $46^{\circ} 51^{\prime} 24^{\prime \prime} \mathrm{N}$; Long. $124^{\circ} 14^{\prime} 40^{\prime \prime} \mathrm{W}$ & $\sim 40$ & 1981-present \\
\hline Waves & NDBC-46041 & Lat. $47^{\circ} 20^{\prime} 24^{\prime \prime} \mathrm{N}$; Long. $124^{\circ} 45^{\prime} 00^{\prime \prime} \mathrm{W}$ & 132 & 1987-present \\
\hline Tides & NOAA-9439040 & Astoria, Columbia River, OR & --- & 1925-present \\
\hline Tides & NOAA-9440910 & Toke Point, Willapa Bay, WA & --- & 1979-present \\
\hline
\end{tabular}




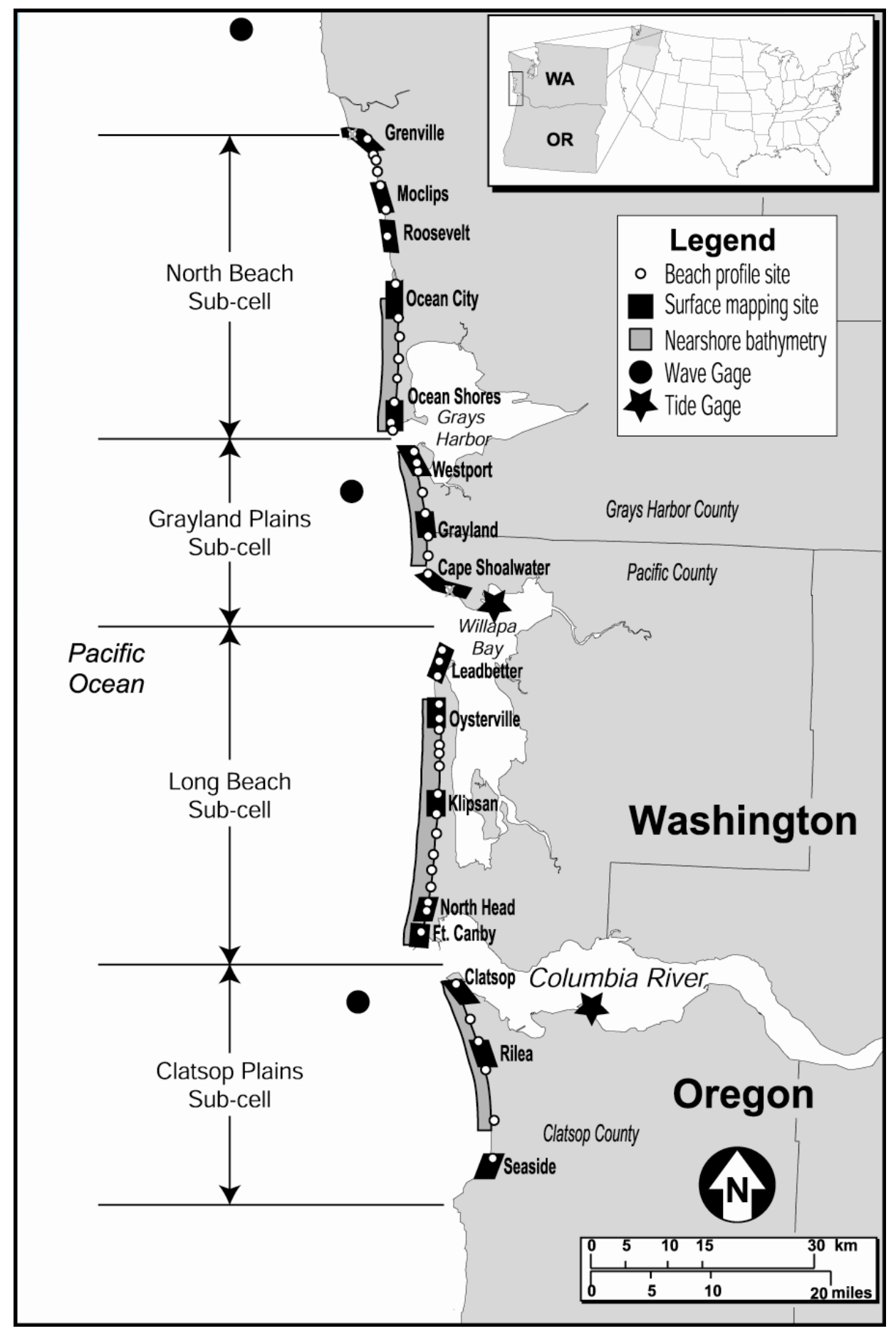

Figure 2. Beach profiles are monitored at 47 sites throughout the littoral cell. Three-dimensional surface maps are collected at 16 sites. Nearshore bathymetry is collected annually along more than half of the littoral cell, nominally at kilometer-spaced transects and in more detail at selected surface map sites. The locations of long-term tide and wave gages are also shown. 


\subsection{Geodetic Control}

In order to reference all beach monitoring data to consistent horizontal and vertical datums, a network of 76 geodetic control monuments was established during the summer of 1997. Monuments are spaced approximately 3-4 km apart throughout the littoral cell. The network has been referenced to the Washington State Plane (South) North American Datum of 1983 (NAD 83) and the land-based North American Vertical Datum of 1988 (NAVD 88). The results of the 1997 survey were published in Daniels et al. (1999). Since that time additional monuments have been added as needed in a continuing effort to maintain the Washington Coastal Geodetic Control Network and to support the planning and land use activities of coastal communities.

\subsection{Topographic Beach Profiles}

Cross-shore topographic beach profiles are collected at 49 locations throughout the littoral cell (Figure 2) to quantify the regional variability of seasonal to inter-annual morphologic change. Profile locations (Table 2) are typically coincident with the location of a control network monument. Table 2 lists the beginning and ending coordinates of each of the beach profiles in the monitoring program. A description of and driving directions to the individual profile locations can be found in Appendix A.

Table 2. Name and location for each of the 49 beach profiles.

\begin{tabular}{cccccc}
\hline Profile & Name & Northing 1 (m) & Easting 1 (m) & Northing 2 (m) & Easting 2 (m) \\
\hline 1 & E2 & 225794.36 & 214700.11 & 225734.16 & 214801.01 \\
2 & SOUTH & 224784.28 & 216647.64 & 224952.33 & 216898.35 \\
3 & L443 & 222775.12 & 217379.61 & 222873.62 & 217739.28 \\
4 & B1 & 221821.27 & 217568.46 & 221946.13 & 217978.11 \\
5 & A1.5 & 220351.73 & 217949.63 & 220446.90 & 218272.15 \\
6 & PIER RM1 & 218426.05 & 218214.73 & 218500.53 & 218652.01 \\
7 & GKAM & 214935.43 & 219043.27 & 214973.51 & 219436.26 \\
8 & BHUX & 211223.23 & 219636.35 & 211270.35 & 219975.43 \\
9 & GP-14109 & 204544.51 & 220355.02 & 204515.41 & 220786.75 \\
10 & DIANA & 199493.91 & 220670.82 & 199539.70 & 220967.07 \\
11 & DAMONS & 193770.05 & 220647.67 & 193748.67 & 220993.84 \\
12 & ET & 191097.81 & 220436.54 & 191031.88 & 220838.53 \\
13 & BUTTER & 187681.80 & 220256.29 & 187628.41 & 220570.37 \\
14 & X1 NORTH & 184272.54 & 220163.19 & 184243.89 & 220375.48 \\
15 & X1 SOUTH & 183978.55 & 220157.48 & 183954.17 & 220363.43 \\
16 & HD-1 & 180591.97 & 223133.14 & 180644.63 & 223459.37 \\
\hline
\end{tabular}




\begin{tabular}{|c|c|c|c|c|c|}
\hline 17 & WORM & 179022.99 & 223529.84 & 179076.78 & 223817.57 \\
\hline 18 & SPICE & 177785.08 & 223798.72 & 177783.81 & 224065.67 \\
\hline 19 & RDAN & 174825.48 & 224415.63 & 174837.17 & 224708.98 \\
\hline 20 & PRUG & 171925.70 & 224794.66 & 171897.18 & 225140.21 \\
\hline 21 & PC068 & 168644.85 & 225072.47 & 168607.78 & 225460.14 \\
\hline 22 & PC064 & 165807.43 & 224645.36 & 165743.83 & 225501.50 \\
\hline 23 & GELF & 163407.50 & 224819.88 & 163317.12 & 225399.85 \\
\hline 24 & CSW & 161117.44 & 228466.28 & 161117.44 & 228466.28 \\
\hline 25 & LB1 & 152826.59 & 226927.59 & 152511.56 & 227435.75 \\
\hline 26 & PC055 & 151125.25 & 226216.35 & 150936.59 & 226851.71 \\
\hline 27 & PC051 & 148673.63 & 226307.28 & 148627.79 & 226882.66 \\
\hline 28 & PC044 & 144566.00 & 226544.10 & 144587.97 & 226960.05 \\
\hline 29 & PC057 & 142558.87 & 226592.94 & 142637.80 & 227064.88 \\
\hline 30 & OYSTER3 & 141082.47 & 226656.67 & 141024.08 & 227100.06 \\
\hline 31 & PC037 & 138882.05 & 226811.82 & 138872.38 & 227028.63 \\
\hline 32 & PC035 & 137709.00 & 226743.17 & 137673.09 & 227018.17 \\
\hline 33 & PC032 & 135799.28 & 226713.18 & 135788.76 & 226967.19 \\
\hline 34 & KLIPSAN2 & 131914.81 & 226566.37 & 131890.83 & 226936.94 \\
\hline 35 & PC021 & 129081.57 & 226384.48 & 129004.65 & 226658.39 \\
\hline 36 & $\mathrm{RICH}$ & 126273.37 & 226114.67 & 126276.59 & 226424.39 \\
\hline 37 & PC014 & 123174.70 & 225883.58 & 123155.23 & 226195.58 \\
\hline 38 & PC008 & 118704.24 & 225457.33 & 118610.52 & 225779.31 \\
\hline 39 & PC025 & 116481.76 & 225188.73 & 116434.64 & 225473.27 \\
\hline 40 & PC004 & 115252.14 & 224990.61 & 115181.85 & 225209.80 \\
\hline 41 & CANBY & 112244.40 & 224293.31 & 112237.25 & 224520.23 \\
\hline 42 & EASTJETTY2 & 104587.22 & 229089.38 & 104710.93 & 229436.92 \\
\hline 43 & IREDALE & 99785.88 & 231088.98 & 99900.93 & 231426.35 \\
\hline 44 & KIM & 96508.79 & 232147.97 & 96603.58 & 232520.89 \\
\hline 45 & RILEA & 92440.71 & 233258.77 & 92546.38 & 233651.59 \\
\hline 46 & DELRAY & 85420.49 & 234322.18 & 85376.47 & 234631.56 \\
\hline 47 & SEASIDERM2 & 80311.88 & 234060.17 & 80087.63 & 234615.29 \\
\hline 48 & CASINO & 196607.68 & 220723.02 & 196564.21 & 221000.06 \\
\hline 49 & JACKSON & 120901.04 & 225694.13 & 120844.05 & 226027.70 \\
\hline
\end{tabular}

\subsubsection{Field Equipment}

Field equipment for topographic beach profiles consists of an RTK DGPS base station and an RTK DGPS rover. The base station consists of a Trimble 4000 series receiver, a Trimble nonmicro centered T1/T2 GPS antenna with a ground plane, a Pacific Crest UHF radio modem, radio antenna, two tripods, and various cables. The rover consists of a Trimble 4000 series GPS receiver, a Trimble micro centered T1/T2 GPS antenna, Pacific Crest radio modem, radio 
antenna, a Trimble TDC1 or TSC1 data logger, and various cables mounted to a backpack. For surveys completed during and after the summer of 2005, one rover consists of a Trimble R8 GPS System, a TSCE data logger, and various cables mounted to a backpack.

\subsubsection{Field Procedures}

An RTK DGPS base station is setup on or near a control monument of the Washington Coastal Geodetic Control Network (Daniels et al., 1999). The GPS antenna is mounted onto a tripod that is leveled over a known monument or a random location. Once leveled, the tripod is secured with sand bags and the antenna is connected to the GPS receiver via a data cable. The radio modem and antenna are attached to the second tripod and connected to the GPS receiver via a data cable (Figure 3). After all connections have been made, the Trimble 4000 series receiver is started using a handheld data logger and the radio modem is turned on.

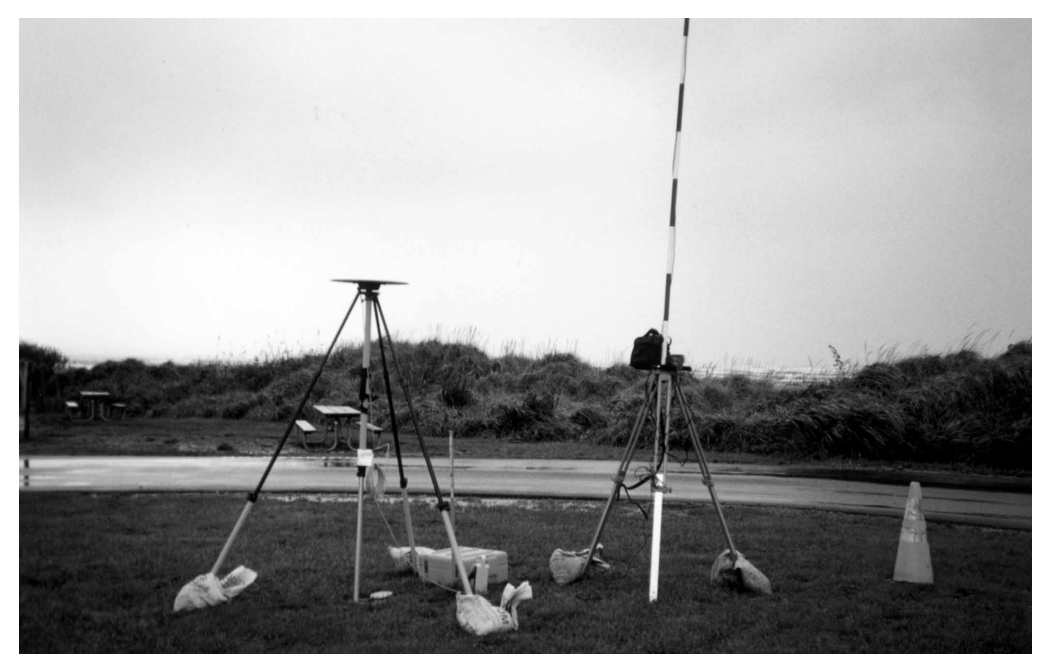

Figure 3. Example setup of GPS equipment. The disc antenna on the tripod (left) receives data from satellites while the antenna on the right transmits this information to a rover receiver collecting data on the beach.

Beach profiles are measured by walking with the rover unit from the landward edge of the primary dune, over the dune crest, to wading depth at spring low tide (Figure 4a). Between 2 and 8 beach profiles are collected during any one low tide and stored in the same file on the data logger. Two or more calibration points per survey are collected for subsequent field calibration, ensuring consistency with the Washington Coastal Geodetic Control Network. 
a)

\section{Coastal Morphology Mapping}

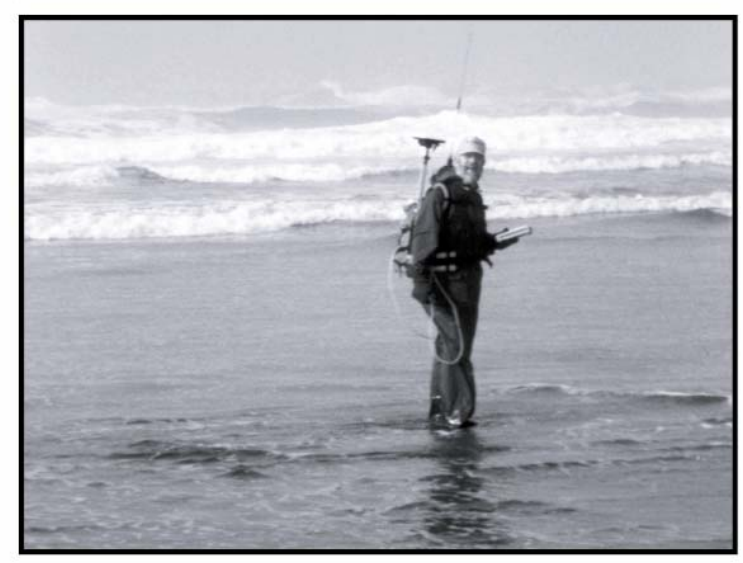

c)

b)
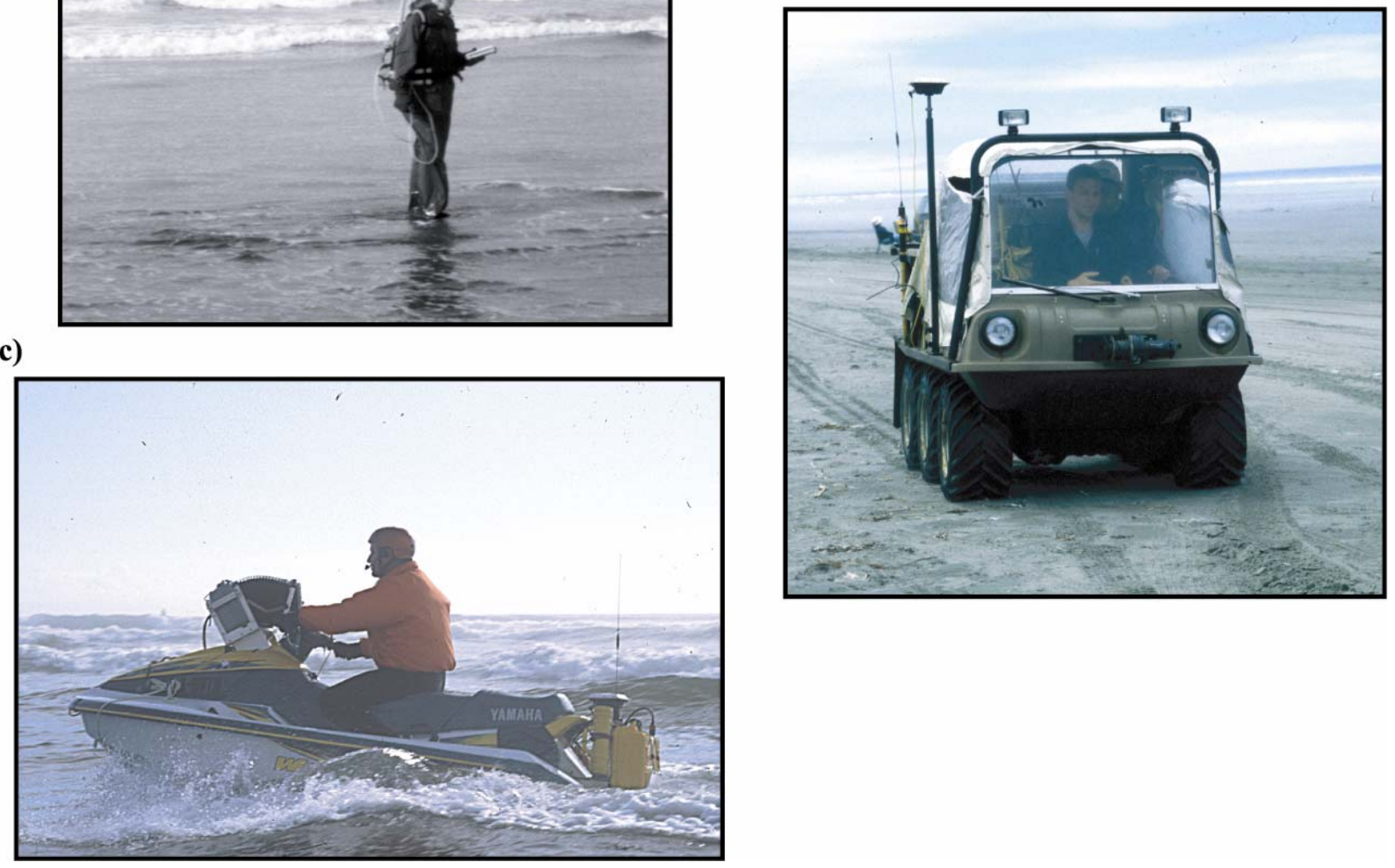

Figure 4. Real Time Kinematic Differential Global Positioning System surveying techniques used in the beach morphology monitoring program. a) Cross-shore topographic beach profiles are collected with a rover receiver, an antenna attached to a backpack, and a hand-held data logger, b) three-dimensional topographic surface maps are collected with the Coastal All-terrain Morphology Monitoring and Erosion Research Vehicle (CLAMMER), and c) nearshore bathymetry is collected with a Coastal Profiling System.

\subsubsection{Horizontal and Vertical Accuracy}

Two types of survey-grade GPS equipment are used in the monitoring program.

The Trimble 4000 series receivers have manufacturer reported root mean square (RMS) accuracies of approximately $\pm 3 \mathrm{~cm}+2 \mathrm{ppm}$ (parts per million) of baseline length (typically 10 $\mathrm{km}$ or less) in the horizontal and approximately $\pm 5 \mathrm{~cm}+2 \mathrm{ppm}$ in the vertical while operating in Real Time Kinematic surveying mode (Trimble Navigation Limited, 1998). The manufacturer reported RMS accuracies for the Trimble R8 GPS Sytem are approximately $\pm 1 \mathrm{~cm}+1 \mathrm{ppm}$ of 
baseline length (typically $10 \mathrm{~km}$ or less) in the horizontal and approximately $\pm 2 \mathrm{~cm}+1 \mathrm{ppm}$ in the vertical while operating in Real Time Kinematic surveying mode (Trimble Navigation Limited, 2004). Baselines are typically less than five kilometers, suggesting a vertical uncertainty of $\pm 6 \mathrm{~cm}$. These reported accuracies are, however, additionally subject to multi-path, satellite obstructions, satellite geometry, and atmospheric conditions that can combine to cause a vertical GPS drift that can be as much as $10 \mathrm{~cm}$ (Sallenger et al., 2003). To minimize these uncertainties a local site calibration is performed during each survey, where between two and five geodetic control monuments are occupied that are known to have a horizontal and vertical accuracy of approximately $2 \mathrm{~cm}$ (Daniels et al., 1999). A three-parameter least squares fit is applied to fix all data points in the current survey to the Washington Coastal Geodetic Control System, within an RMS error typically less than $4 \mathrm{~cm}$ in the vertical, regardless of the phase of the GPS drift. Uncertainties in GPS position estimates also arise from collecting beach profiles by walking with a GPS antenna mounted on a backpack. Prior to fall 2000, GPS operators determined the horizontal location of the beach profiles in the field by locating permanent markers set in the dunes. The horizontal variability from the dune toe to the waters edge between subsequent surveys could be as much as tens of meters. Since fall 2000, a Trimble model TSC1 or TSCE data logger has been used that allows for simultaneous navigation and data collection, reducing the horizontal variability between subsequent surveys to typically less than $1 \mathrm{~m}$. These horizontal deviations typically result in negligible vertical uncertainties due to the wide gently sloping beaches of the CRLC. However in highly three-dimensional dune fields, vertical uncertainties associated with horizontal deviations between subsequent profiles could be significant.

To test the vertical repeatability of our beach profile methodology, three different GPS operators collected the same profile data in a single day (Ruggiero and Voigt, 2000). This test resulted in mean vertical offsets between the three surveys of approximately $2 \mathrm{~cm}$, and RMS deviations of approximately $4 \mathrm{~cm}$ (Figure 5). Assuming that the vertical uncertainties are statistically independent, we combine the GPS error $(\sim 6 \mathrm{~cm})$, the calibration error $(\sim 4 \mathrm{~cm})$, and the repeatability error $(\sim 4 \mathrm{~cm})$ in quadrature by taking the square root of the sum of the squares. Therefore, the methodology used in the monitoring program can only reliably detect beach elevation change greater than approximately $8 \mathrm{~cm}$. While not as accurate as standard terrestrial 
surveying using a rod and level, walking the profiles with a GPS backpack is justified by both the reduction in survey time and the large seasonal changes observed on the high-energy beaches of the CRLC.
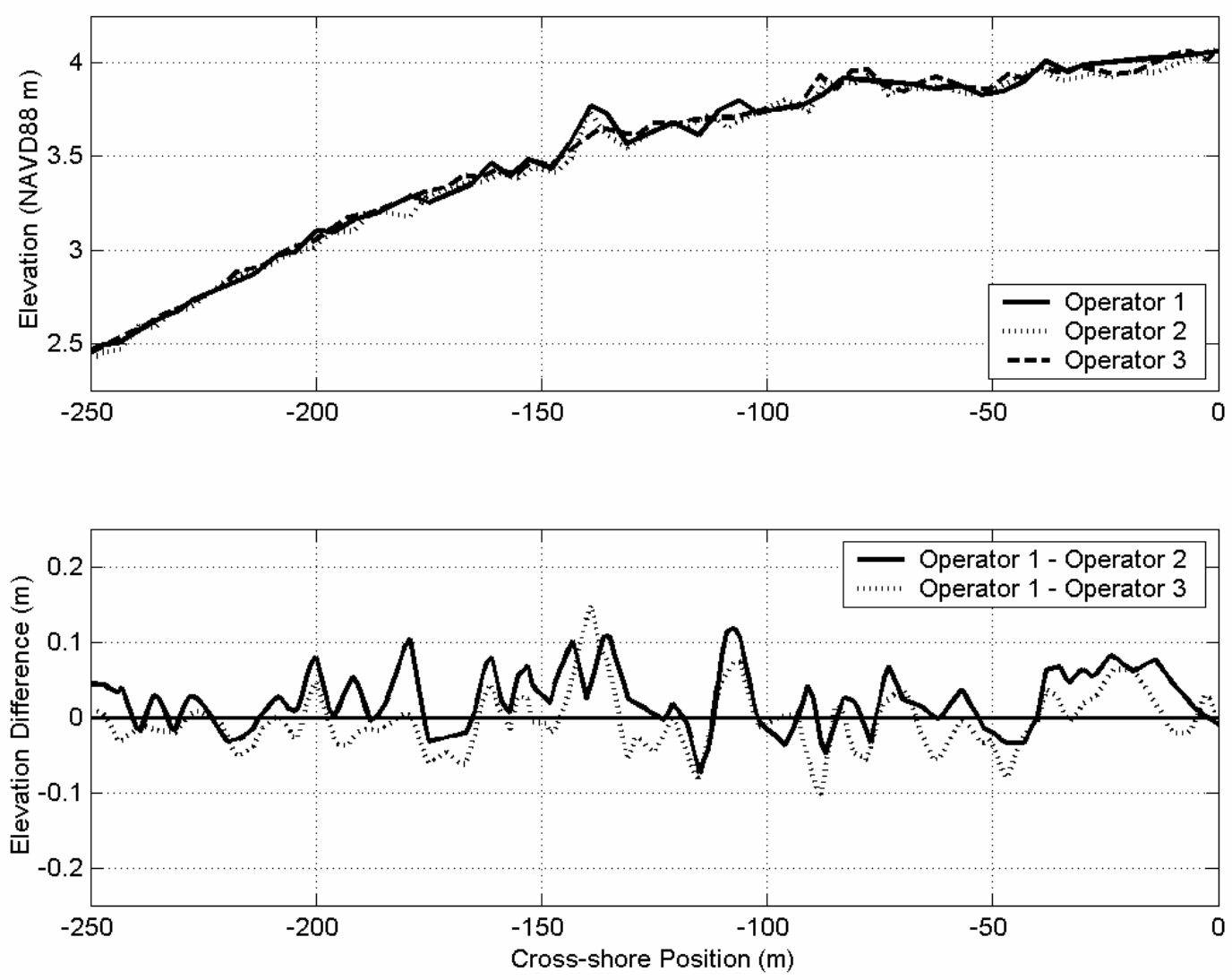

Figure 5. Repeatability of the cross-shore beach profile methodology. The top panel shows a section of a beach profile as measured by three GPS operators. The bottom panel features the elevation difference between the subsequent profiles indicating the resolution of the beach profile data collection technique.

\subsubsection{Data Processing}

Data calibrations (also referred to as horizontal and vertical adjustments) reduce discrepancies between local control and GPS-derived coordinates. Typically a field calibration is performed, and if not, the calibration is performed in the office to constrain the horizontal and vertical coordinates with the Washington Coastal Geodetic Control Network (Daniels et al., 1999). A calibration is accomplished by obtaining two to five calibration points at monuments of known 
vertical and horizontal position in the vicinity of the survey area. Calibration points are measured by centering the GPS antenna over a known monument at a set height and recording data for approximately 30 seconds. If the precisions are satisfactory ( $<5 \mathrm{~cm}$ error), the point is stored and applied to the survey. The Trimble Survey Controller software automatically performs a spatial correction on all survey points collected and matches the grid points to the known values.

Field data stored in the data logger is downloaded to one of Trimble's proprietary office software programs (Trimmap, TSOffice, and TGOffice have all been used). The office software allows for further quality assurance and quality control (QA/QC) through visualization, calibration and archiving. The data is then exported from the office software to an ASCII text file that is imported into Matlab (The Mathworks, Inc.).

Matlab scripts are used to visualize individual beach profiles and compare them to previously collected data for final QA/QC. Following final QA/QC, the entire data file is split into individual cross-shore topographic profiles and exported as individual ASCII text files (e.g., prof_21_su00.out). Data are reported as x, y, z triplets (Easting, Northing, Elevation) with the horizontal datum Washington State Plane South NAD $83 \mathrm{~m}$, and the vertical datum NAVD $88 \mathrm{~m}$. Finally, a Matlab script is used to export all of the data collected during one survey campaign into another ASCII text file. This file is then imported into Excel and saved as a DBF file (e.g., profiles_summer_2000.dbf) in order to facilitate the use of these data with a wide variety of software packages (e.g. GIS platforms).

\subsection{Sediment Size Distributions}

Surface sediment samples are collected at each beach profile location during each summer surveying campaign.

\subsubsection{Field Procedures}

Surface sediment samples are collected by hand (typically several hundred grams) within the dune, at the dune toe, at mid-beach and within the swash zone at low tide along a corresponding topographic beach profile. Due to a limited amount of processing time, the mid beach sediment samples are the only samples collected from summer 2002 on and processed consistently. 


\subsubsection{Data Processing}

Sediment samples are taken to a sediment lab where sand grain size distributions are determined using American Society for Testing and Materials (ASTM) approved dry sieves at quarter-phi intervals following current EPA protocols for sediment analysis in the state of Washington (Tetra Tech Inc., 1986). Sediment samples are emptied into Gilson Model No. SC-152 9 by 9 inch metal drying trays and placed into a Quincy Lab Inc. Model 40 GC lab oven set at a temperature of $90^{\circ} \mathrm{C}\left(200^{\circ} \mathrm{F}\right)$. Samples are allowed to dry for 24 hours and are then placed into labeled plastic bags and stored until sorting. Before sorting, sample sizes are reduced to a target weight between 50 and 100 grams. Sediment samples are passed through a Sepor Inc. sediment splitter in order to reduce sample weight without adding bias to the process. The split samples are weighed to ensure target weight and recorded into a spreadsheet that allows for quick statistical analysis of sand grain size distributions. Split samples of target weight are poured into a stack of ASTM E11 Specification USA Standard Testing Sieves and placed into a W.S. Tyler Model R x 29 RoTap for 15 minutes. The Ro-Tap agitates the samples, sorting the sediment into its respective sieve size. Once sorting is complete, the sieve stack is dismantled and sediment on each sieve is collected, weighed and entered into the spreadsheet column corresponding with sieve size. Although this process is relatively error free, some error is generated when sediment is caught within the sieves. In order to reduce error caused by lost sediment, sample weights are compared before and after they are sorted. Sorted samples that weigh below $99.0 \%$ or above $100.99 \%$ of the original sample weight are discarded and not recorded. A fresh sediment sample is taken from the original sample bag and the process is restarted.

\subsection{Topographic 3-D Beach Surface Maps}

Whereas analyses of beach profiles can reveal the cross-shore variability in beach change, little information about the alongshore component of beach change can be extracted from this data. In lieu of multiple closely spaced cross-shore transects, three-dimensional topographic beach surface maps are generated by mapping the sub-aerial beach surface. To determine both the alongshore and cross-shore morphologic variability of the beach, surface maps are collected biannually at 16 sites (Figure 2, Table 3), totaling more than $60 \mathrm{~km}$ of alongshore distance. 
Survey frequency is increased in areas that are highly dynamic (e.g., Ocean Shores, WA) in an attempt to determine shorter-scale temporal changes of the beach planform.

Table 3. Name and bounding coordinates for each of the 16 beach surface maps.

\begin{tabular}{cccccc}
\hline Surface Map \# & Name & Northing 1 (m) Easting 1 (m) Northing $\mathbf{2}(\mathbf{m})$ Easting 2 (m) \\
\hline 1 & GRENVILLE & 225862.00 & 214789.00 & 223412.00 & 217536.00 \\
2 & MOCLIPS & 218742.00 & 218510.00 & 214823.00 & 219353.00 \\
3 & ROOSEVELT & 213117.00 & 219522.00 & 209027.00 & 220035.00 \\
4 & OCEAN CITY & 204655.00 & 220215.00 & 199608.00 & 220537.00 \\
5 & OCEAN SHORES & 187583.00 & 220249.00 & 183657.00 & 220105.00 \\
6 & WESTPORT & 181088.00 & 223121.00 & 177084.90 & 224031.00 \\
7 & GRAYLAND & 171987.00 & 224993.00 & 168613.00 & 225290.00 \\
8 & NORTH COVE & 163419.00 & 225016.00 & 160868.00 & 228528.00 \\
9 & LEADBETTER POINT & 153229.00 & 227210.00 & 148562.00 & 226659.00 \\
10 & OYSTERVILLE & 142715.00 & 226833.00 & 138783.00 & 226928.00 \\
11 & KLIPSAN & 131964.00 & 226670.00 & 128609.00 & 226486.00 \\
12 & NORTH HEAD & 117127.00 & 225326.00 & 113948.00 & 224672.00 \\
13 & FORT CANBY & 113280.00 & 224460.00 & 110154.00 & 224188.00 \\
14 & CLATSOP & 105159.00 & 229197.00 & 101866.00 & 230547.00 \\
15 & RILEA & 96593.00 & 232392.00 & 93003.00 & 233370.00 \\
16 & SEASIDE & 80395.00 & 234166.00 & 77238.90 & 233556.00 \\
\hline
\end{tabular}

\subsubsection{Field Equipment: The CLAMMER}

Field equipment for surface maps consists of an RTK DGPS base station, an RTK DGPS rover, and an amphibious all-terrain vehicle. The base station setup is identical to that used for the beach profiles. The rover consists of a Trimble 4700 GPS receiver, a Trimble micro centered T1/T2 GPS antenna, Pacific Crest radio modem, radio antenna, a Trimble TDC1 or TSC1 data logger, and various cables mounted to a six-wheel drive amphibious all-terrain vehicle called the CLAMMER (CoastaL All-terrain Morphology Monitoring and Erosion Research Vehicle). The CLAMMER is a model MAX IV vehicle made by Recreatives Industries INC (pre Fall 2002). It was chosen as the surface map survey vehicle because of its all-terrain and amphibious capabilities as well as the low weight to tire size ratio (Figure 4). The weight distribution is important because while surveying at low tide the CLAMMER is often driven over Razor clam beds that are sensitive to pressure. The MAX IV manufacturer reports that the vehicle applies less pressure on the ground than a human footprint, causing minimal damage to invertebrate 
populations. In October of 2002, the CLAMMER was replaced with a similar vehicle called the KD-V. The KD-V is an ARGO Vanguard 2 6-wheel drive amphibious off road vehicle. For surface maps completed after the summer of 2005, the rover consists of a Trimble R8 GPS System, TSCE data logger, and various cables mounted to the KD-V.

\subsubsection{Field Procedures}

The RTK DGPS base station is setup in a similar fashion as for collecting beach profiles. Surface map data is stored onboard the CLAMMER using either Aspen RTK (Trimble) software on a ruggedized personal computer (pre-summer 2000) or using a Trimble TDC1, TSC1, or TSCE data logger (post-summer 2000). Individual sites are each approximately $4 \mathrm{~km}$ in length and hundreds of meters in width, spanning the area between the toe of the primary dune and the swash zone. The CLAMMER, traveling along the beach at approximately $6 \mathrm{~m} / \mathrm{s}$, collects individual point measurements every 5 - $10 \mathrm{~m}$. Individual point measurements are densely spaced in the alongshore direction to resolve relatively small-scale features such as beach cusps,

and are over long enough distances to resolve larger scale, potentially migrating features such as mega-cusps, rip-current embayments, and sand waves. The cross-shore distance between alongshore transects is typically 20 - $30 \mathrm{~m}$ but is determined in the field based on cross-shore breaks in beach slope, such as at crests and troughs of swash bars and sand berms.

\subsubsection{Horizontal and Vertical Accuracy}

The survey-grade GPS equipment and site calibration process are discussed in section 2.3.3. The non-uniformly spaced raw data, typically 5,000 to 10,000 points per surface map, feature accuracies better than approximately $0.05 \mathrm{~m}$ in the horizontal.

Uncertainties in vertical GPS position estimates also arise from collecting surface map data while on a moving platform, including vehicle bounce and tires sinking into the sand. While these additional errors are not readily measurable, comparisons with beach profile surveys suggest that they are small $(\sim 5 \mathrm{~cm})$. Assuming that the vertical uncertainties are statistically independent, we combine the GPS error $(\sim 6 \mathrm{~cm})$, the calibration error $(\sim 4 \mathrm{~cm})$, and the vehicle error $(\sim 5 \mathrm{~cm})$ in quadrature by taking the square root of the sum of the squares. Therefore, the 
methodology used in collecting topographic beach surface maps can only reliably detect vertical beach elevation change greater than approximately $10 \mathrm{~cm}$.

\subsubsection{Data Processing}

Data calibrations (also referred to as horizontal and vertical adjustments) are performed in a similar manner as for beach profiles. Field data stored in the ruggedized laptop or data logger is downloaded to a Trimble proprietary software program. Pathfinder Office (pre-summer 2000), Trimmap, TSOffice or TGOffice have all been used. The Trimble software allows for further quality assurance and quality control (QA/QC) through visualization, calibration and archiving. The data is then exported from the office software to an ASCII text file that is imported into Matlab for final QA/QC. The non-uniformly spaced raw data (typically 5,000 to 10,000 points) are typically mapped onto a uniform 2-dimensional gridded surface via triangle-based, weighted linear interpolation, allowing for comparison with subsequent data sets. The surface maps are compared to earlier data and visualized in a variety of ways. Following final QA/QC the raw data points are exported to individual ASCII text files. Data are reported as $\mathrm{x}, \mathrm{y}, \mathrm{z}$ triplets (Easting, Northing, Elevation) with the horizontal datum Washington State Plane South NAD 83 m, and the vertical datum NAVD 88 m (e.g., sm_Seaside_su97.out).

\subsection{Shoreline Reference Feature Mapping}

Erosion reference features, such as scarps or drift lines, are being mapped on rapidly eroding beaches by walking the feature in the alongshore direction with an RTK DGPS backpack. These data are used to complement the historical shoreline change analyses being conducted by digitizing historical NOS topographic sheets and aerial photography (Kaminsky et al., 1999). Shoreline change reference features also serve to expand the regional coverage between crossshore profiles and define a landward boundary to the beach surface maps.

\subsubsection{Field Equipment}

Field equipment for shoreline reference feature surveying consists of an RTK DGPS base station and an RTK DGPS rover on a backpack. 


\subsubsection{Field Procedures}

The RTK DGPS base station is setup in a similar fashion as for collecting beach profiles. The surveyor walks with the RTK rover unit along the base of the erosional scarp, toe of dune, or landward extent of the vegetation line.

\subsubsection{Horizontal and Vertical Accuracy}

The survey-grade GPS equipment and site calibration process are discussed in section 2.3.3. Uncertainties in horizontal positions also occur when there is no clear toe of an erosion scarp or dune, when debris (i.e., driftwood) prevents the GPS operator from following the scarp toe, or when satellite visibility is diminished due to overhead trees and debris. These additional uncertainties are not readily measurable but combine to limit the horizontal uncertainty of this technique to be approximately 1-3 m. Additional uncertainties in vertical GPS position estimates also arise from the GPS operator being prevented from walking exactly at the scarp toe. Therefore, a conservative estimate of the total vertical uncertainty is approximately $1 \mathrm{~m}$.

\subsubsection{Data Processing}

Data calibrations (also referred to as horizontal and vertical adjustments) are performed in a similar manner as for beach profiles.

Field data stored in the data logger is downloaded to a Trimble proprietary office software program (Trimmap, TSOffice or TGOffice have all been used). The office software allows for further quality assurance and quality control (QA/QC) through visualization, calibration and archiving. The data is then exported from the office software to an ASCII text file that is imported into Matlab. Matlab scripts are used to visualize individual reference feature surveys and compare them to data collected earlier for final QA/QC. Following final QA/QC, the entire data file is reported as $\mathrm{x}, \mathrm{y}, \mathrm{z}$ triplets (Easting, Northing, Elevation) with the horizontal datum Washington State Plane South NAD 83 m, and the vertical datum NAVD 88 m (e.g., Ocean_Shores_030597.out). 


\subsection{Nearshore Bathymetry}

The sub-aerial, or visible beach comprises only a portion of the active coastal zone. Variability in sub-aqueous morphology can influence the amount of energy from waves that is available to impact the shoreline and cause beach change. It has historically been very difficult and expensive to collect data in this highly dynamic region and only a few coastlines in the world have sufficient nearshore data to quantify this variability. The Coastal Profiling System (CPS), a hydrographic surveying system mounted on a Personal Watercraft (PWC) originally designed by Oregon State University (Beach et al., 1996; Côté, 1999; MacMahan, 2001) to collect data in energetic nearshore environments, is now being used in the CRLC to collect regional scale nearshore bathymetric data (Figure 4).

The CPS was designed to improve at least three of the limitations of existing nearshore surveying platforms (Côté, 1999).

1. Increase our ability to survey in shallow water and overlap with sub-aerial beach profiles, closing the existing data gap within the surf zone.

2. Improve the efficiency and accuracy of echo sounder surveys to approximately $10 \mathrm{~cm}$, while decreasing the limitations imposed by environmental conditions in the surf zone.

3. Increase the mobility of the survey system such that it can be easily transported to a variety of field locations.

This section describes the bathymetric and co-located topographic beach profile data collected in the CRLC, beginning with a pilot effort in 1998 and eventually becoming a full component of the beach monitoring program in 1999.

\subsubsection{Summer 1998 Pilot Study}

In 1998, a pilot effort was initiated to determine whether the CPS could be used as a regional monitoring tool in the Pacific Northwest. A 2-3 kilometer representative section of each of the four sub-cells of the CRLC (Figure 2) was surveyed in late July and early August 1998. 


\subsubsection{Field Equipment}

Combining the high accuracy positioning of DGPS, the efficiency of an acoustic echo sounder, and the mobility of a personal watercraft, the CPS provides a fast and accurate method to obtain sub-aqueous bathymetric profiles. The original CPS (CPSI) was configured on a Yamaha Waverunner III 2 cycle, 62 horsepower PWC that is $3 \mathrm{~m}$ long and $1.1 \mathrm{~m}$ wide (Figure 6). A Meridata MD 100 fan beam echo sounder is used with the transducer (12.5 ${ }^{\circ}$ beam width) mounted in the hull at the stern of the PWC. The MD 100 operates at $200 \mathrm{kHz}$, samples at $1 \mathrm{~Hz}$, and is capable of measuring in water depths ranging from $1-180 \mathrm{~m}$, with a resolution of approximately $10.0-\mathrm{cm}$. The CPSI incorporates a Trimble (4000 series) RTK-DGPS operating at $5 \mathrm{~Hz}$ with a land-based antenna mounted over a known reference station. The rover antenna is mounted approximately in the center line of the boat, directly over the echo sounder transducer, on an A-frame at the stern of the PWC. A daylight-readable Liquid Crystal Display (LCD) provides the PWC operator with GPS status, speed of vessel, and depth information. Data from the CPS are collected in an onboard computer system and stored on a 32 MB PCMCIA card.

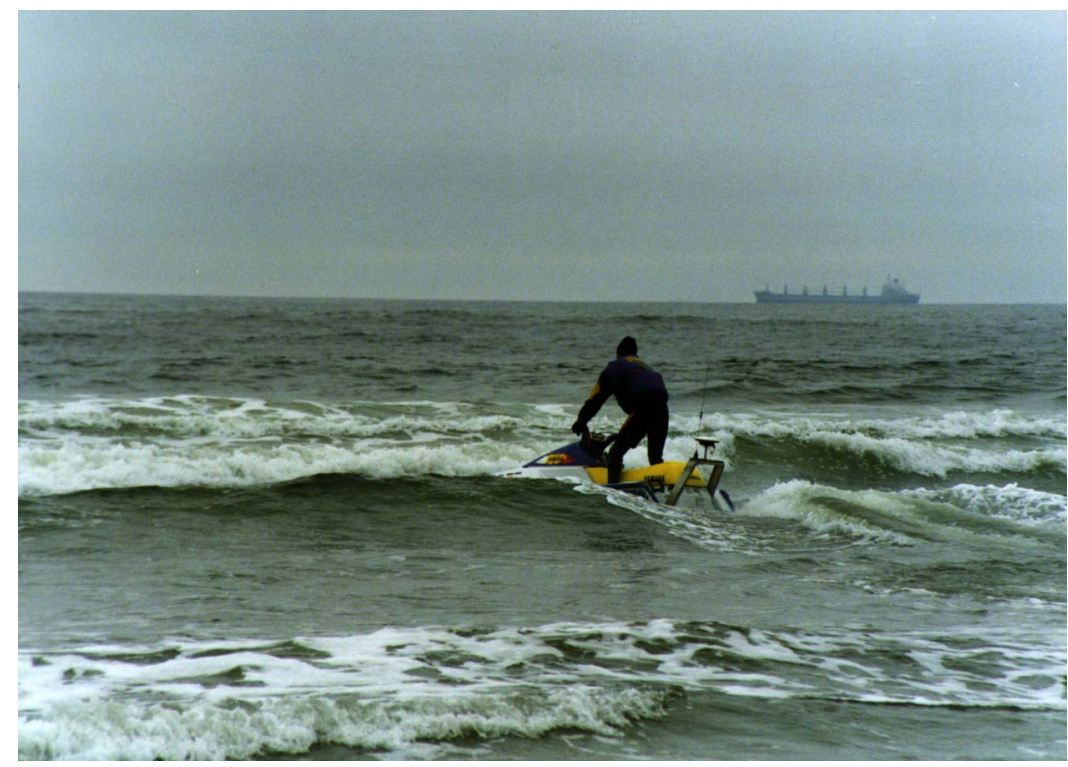

Figure 6. Original Coastal Profiling System (CPSI) being launched. 


\subsubsection{Field Procedures}

During the original ground-truthing of the CPSI at the SandyDuck '97 field experiment, operation procedures were dependent on the infrastructure of Field Research Facility (FRF) in Duck, North Carolina. For application to a regional beach morphology monitoring in the CRLC, new controls on surveying, additional personnel, and safety procedures had to be developed to complete nearshore bathymetric data collection.

At each survey site, the GPS base station was located over a known geodetic control monument (Daniels et al., 1999). Prior to launching the CPSI, discrepancies between local control and GPSderived coordinates were reduced by conducting a field calibration (also referred to as horizontal and vertical adjustments). This calibration was accomplished by obtaining between two and three calibration points at markers of known vertical and horizontal position in the vicinity of the survey area. Calibration points were measured by initializing the CPSI system, centering the GPS antenna over a known marker at a set height and recording data for several minutes. If precisions were satisfactory, the calibration points were used to perform a least squared fit spatial correction on all survey points collected to constrain the horizontal and vertical coordinates to the Washington Coastal Geodetic Control Network (Daniels et al., 1999). The CPSI was completely initialized on land and then recorded data continuously until the PWC was retrieved from the water and powered down. While data was collected continuously, the CPSI operator only concentrated on maintaining data quality while moving along cross-shore transects, beginning in deep water, approximately 10-12 m below NAVD88, and ending within the surf zone. Three range poles were used on the beach to align the individual shore perpendicular transects. This cross-shore operation of the CPSI minimized the effect of roll and pitch on depth estimates. The alongshore spacing between cross-shore profiles was typically around $200 \mathrm{~m}$. The CPS surveys were conducted near high tide to maximize the landward limit of the profile measurements. In some cases, beach topography (sub-aerial) measurements were made at low tide within approximately 24 hours of the bathymetry measurements using the CLAMMER. 


\subsubsection{Horizontal and Vertical Accuracy}

The CPSI was first tested in the nearshore during February 1996 at Agate Beach, Oregon as part of the High Energy Beach Experiment (Beach et al., 1996). Following these initial field trials the primary test of the system took place in October 1997 at the SandyDuck '97 field experiment at the USACE Field Research Facility (FRF) in Duck, North Carolina where the bathymetric data collected by the CPS were compared against the data collected by the CRAB (Birkemeir et al., 1984). Error analyses from these tests indicate that the system typically maintains sub-decimeter vertical accuracy (Cote, 1999). Horizontal uncertainties for individual points are approximately $0.05 \mathrm{~m}$, based solely on GPS accuracies and coordinate system calibrations. However, the CPSI could at times be up to approximately $100 \mathrm{~m}$ off of a true shore perpendicular transect due to the methodology of sighting range poles on the beach.

\subsubsection{Data Processing}

The GPS and echo sounder were sampled at different rates and recorded separately. However the need to estimate the tidal elevation of the water surface is eliminated by the co-collection of depth data and an accurate GPS vertical position. The GPS data, sampled at $5 \mathrm{~Hz}$, was recorded in the WGS84 datum. The program Corpscon (US Army Corps of Engineers) was used to convert to the Washington State Plane (South) NAD83 horizontal datum and the NAVD88 landbased vertical datum. A cubic spline interpolation using a piece-wise polynomial fit obtains the GPS coordinates for the echo sounder depth at a specified location and time. The elevation of both data streams are then subtracted to obtain the depth of the seafloor, $h$, in NAVD88

$$
h=z_{g p s}-\Delta z+h_{\text {sonar }}
$$

where $z_{g p s}$ is the elevation of the GPS antenna phase center in NAVD88, the correction factor $\Delta z$ is a fixed vertical distance between the echo sounder transducer and the GPS antenna phase center, and $h_{\text {sonar }}$ is the depth to the seafloor below the transducer (Figure 7). Although the CPSI collects data continuously, beach profiles are only derived from measurements taken while driving onshore in order to minimize the influence of waves on the measurements. Individual data points below the echo sounders blanking interval $(0.0-0.6 \mathrm{~m})$ and points $1.75 \mathrm{~m}$ above a linear regression through the data were removed as outliers. A second pass through the data 
removed points $0.5 \mathrm{~m}$ vertically different from nearest neighbor data points. These two steps typically reduce data density by approximately $15 \%$. Next a ten point median filter is used to smooth the remaining high frequency noise.

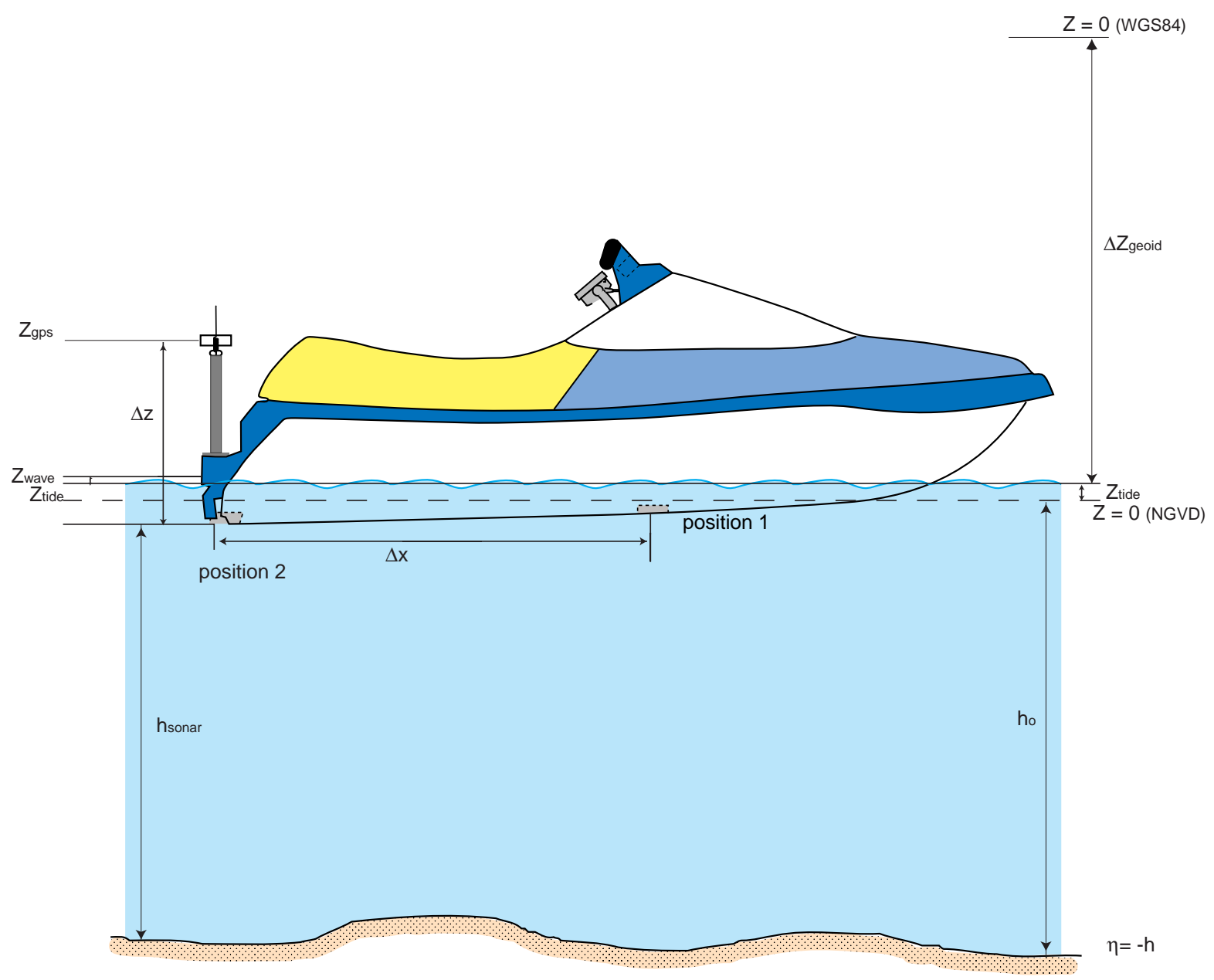

Figure 7. The Coastal Profiling System records vertical elevations relative to a land based vertical datum in meters. The vertical component of bathymetry combines several variables as indicated here.

The final data processing step used on the 1998 data set is an elevation correction resulting from differences between the actual speed of sound in water and the preset speed of sound that was typically set equal to $1450 \mathrm{~m} / \mathrm{sec}$. The speed of sound calibration uses the UNESCO (1982) algorithm (2) for the computation of the speed of sound in seawater, $U$, as a function of salinity, temperature, and pressure 


$$
U(S, T, p)=C_{w}(T, p)+A(T, p) S+B(T, p) S^{3 / 2}+D(T, p) S^{2}
$$

where $S$ is salinity in psu, $T$ is temperature in degrees Celsius, $p$ is pressure in decibels, and $C_{w}$, $A, B$, and $D$ are constants.

The corrected depth measurement, $h_{c}$, is obtained by multiplying the depth, $h$, from (1), by the ratio of the calculated speed of sound, $U$, to the assumed constant value.

$$
h_{c}=(U / 1450) * h
$$

Data from each day of collection in 1998 have been processed in the above manner and stored as Easting, Northing, Elevation triplets in an ASCII file in the following directory: nearshore_bathymetryldata_98|NorthBeach|bathyloutput_raw.

Profiles in the subsequent years of this surveying campaign were collected along preset track lines. In order to compare the 1998 data to these subsequent profiles a further processing step is necessary. Both the bathymetry data and the topography data are mapped onto a uniform 2dimensional gridded surface from which beach profiles falling along the subsequent track lines are extracted. These profiles are considered the final output for the 1998 data set and are located in nearshore_bathymetryldata_98|NorthBeach|bathyloutput_fin.

\subsubsection{Regional nearshore monitoring, 1999-2003}

Between summer 1998 and summer 2003, cross-shore profiles were collected using a second generation Coastal Profiling System (hereinafter referred to as CPSII, Figure 8). Each of the five sections surveyed in 1998 were surveyed again in 1999, 2000, 2001, 2002, and 2003.

Additionally, tens of profiles (approximately 1.0-km spacing) covering most of the rest of the CRLC have also been collected. 


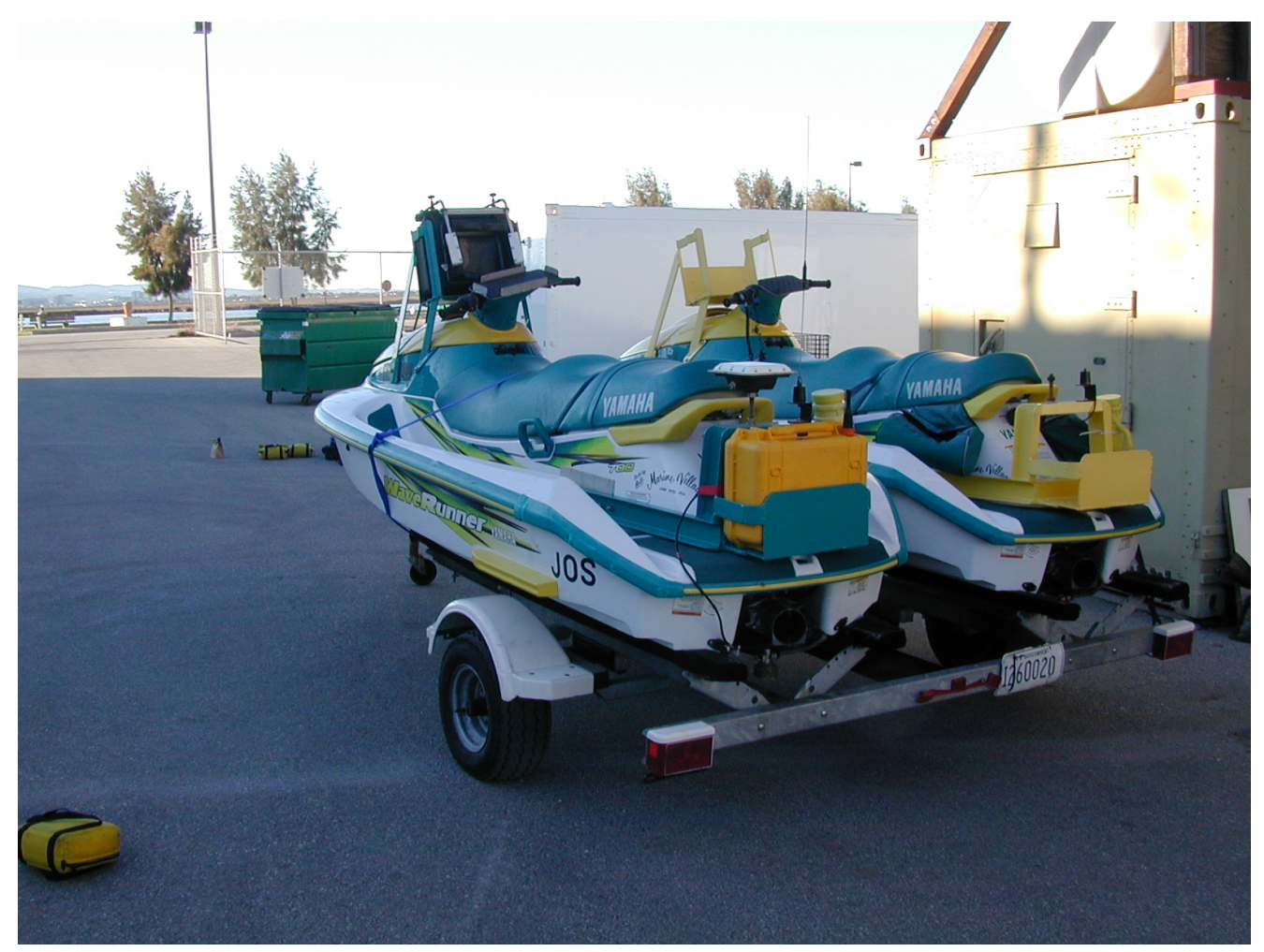

Figure 8. Second generation Coastal Profiling System (CPSII) in dry dock.

\subsubsection{Field Equipment: Second Generation Coastal Profiling System}

The CPSII, cooperatively designed with the University of Florida (MacMahan, 2001), also consists of a personal watercraft equipped with a GPS receiver and antenna, an echo sounder, and computer running hydrographic survey software. Modifications to the original system include: 1) a monitor for visual aid, 2) an echo sounder with a higher sampling frequency, 3) a keypad for operator control, and 4) surveying software for navigation, data collection, and data analysis (MacMahan, 2001).

The CPSII PWC used was a 1998 3-person Yamaha Venture 700 Wave Runner. This model was chosen because of its stability, compartment space, and relatively low price. The 3-person PWC measures $3.15 \mathrm{~m}$ in length, $1.25 \mathrm{~m}$ in width, and $1.05 \mathrm{~m}$ in height. During 1999 and 2000 only 1 of the 2 boats (Jose) was used to collect data while the second boat (Josb) served as water-based support for safety. During normal surveying operation, the wave runner travels at approximately $3 \mathrm{~m} / \mathrm{s}$ (5 knots) and can operate for approximately 3-5 hours on one $50 \mathrm{~L}$ fuel tank. The 
instruments are placed in the compartment space located under the back seat, on a bracket at the stern on the vessel, and on brackets in the forward part of the vessel in front of the handlebars. In the storage space under the rear seat of the PWC, a platform (false bottom) was mounted with a watertight case located on the underside containing a DC-DC converter and an in-line fuse. On top of the platform are two watertight cases, which house the GPS, computer, and echo sounder electronics. The computer case contains the echo sounder and the laptop computer. This case has six external watertight connectors: one is for serial communication with the GPS, one for the echo sounder transducer, one for the external screen, one for the external 17 button keypad, one for power, and one spare. The complete system is powered by two gel cell 12-volt marine batteries, configured in series and housed in a Pelican box mounted on the bracket at the stern of the PWC. The system draws approximately 24 volts at approximately 2.8 amps (MacMahan, 2001).

Horizontal and vertical positioning of the CPSII is obtained using a Trimble 4700 GPS receiver, which is enclosed in a waterproof Pelican box stowed in the storage compartment underneath the seat. The GPS case also includes the GPS radio modem (Pacific Crest) that is used to communicate with the base station. A small bracket is attached on top of the stern of the vessel for mounting the GPS antenna and the radio antenna. The GPS antenna is mounted approximately $90 \mathrm{~cm}$ directly above the echo sounder transducer.

A Bathy-500 single-frequency echo sounder (manufactured by Ocean Data Equipment Corporation) with a $208 \mathrm{kHz}$ transducer was used. This echo sounder has adjustable gains, offset, serial outputs, and speed of sound control. The sampling rate is a function of water depth with the highest sampling rate of $8 \mathrm{~Hz}$ applied in shallow water $(0-10 \mathrm{~m})$. The resolution of the echo sounder is approximately $3 \mathrm{~cm}$. The transducer has a 10 degree conical beam width and generates a pulse at $208 \mathrm{kHz}$. The echo sounder transducer is mounted on a removable plate on the underside of the vessel at the stern just below the engine jet. It is located $29.2 \mathrm{~cm}$ below the waterline of the unmanned wave runner. The electronics of the echo sounder were reconfigured and along with the laptop computer (Toshiba Libretto 100 CT until 2000 and replaced by a Palmax Pen Computer following 2000), placed in a watertight Pelican Case. The CPSII collects 
data at $5 \mathrm{~Hz}$ and while traveling at $3 \mathrm{~m} / \mathrm{s}$ generates a depth sounding every 0.6 meters along the sea floor.

HYPACK (Coastal Oceanographics Inc.) hydrographic surveying software is used as the data synchronization software and navigation system. Hypack allows visual observation of the transect, distance offline, depth, latitude, longitude, easting, northing, corrected depth, filename, line number, satellite quality, number of satellites, collection mode, and recording mode. All of this information is useful to the operator when collecting hydrographic data.

Navigation and surveying are aided by the use of a monitor (a $25.4 \mathrm{~cm}$ ) Computer Dynamics VAMP 1000 day light readable screen with 900 NIT reading) which is mounted in a watertight case on a bracket forward of the handlebars. A retractable bellows is mounted onto the screen case, sheltering the screen from direct sunlight to allow better viewing of the external monitor. A 17-button programmable Logic Controls keypad $(24 \mathrm{~cm} \mathrm{X} 8.9 \mathrm{~cm} \mathrm{X} 3.2 \mathrm{~cm})$ is placed in a waterproof radio bag mounted on the handlebars to allow the user to start and stop data collection and modify the screen view.

In the spring of 2001, the second PWC (Josb) was outfitted to collect data concurrently with boat 1 (Jose). The second boat was outfitted in a similar manner to boat 1 with a few key differences, including: 1) the echo sounder is a Bathy-500 MF (multiple frequency) from ODEC using an 8 degree conical beam width transducer, and 2) the onboard computer is a Palmax Pen Computer (266MHz, Pentium, Windows 98).

\subsubsection{Field Procedures}

As HYPACK allows for surveying within a user-defined coordinate system, in this case NAD83 Washington State Plane (South) and NAVD88, collecting land based control points is no longer necessary with the CPSII. The GPS base station is set up over a known survey monument within the Coastal Geodetic Control Network (Daniels et al., 1999) and survey accuracy data is stored by the HYPACK software in the appropriate datum. 
Another significant improvement with the CPSII is the ability to survey preset track lines, eliminating the need for range poles on the beach. The preset track lines for each of the sub-cells are included in Inearshore_bathymetry|Hypack_Line_Files|. Data is now collected only when the PWC operator selects a transect. The PWC operator maneuvers the vessel offshore to either a target depth (typically around $12 \mathrm{~m}$ ) or a target easting along a preset track line. Each profile extends a deep-water limit ranging between 10 and $16 \mathrm{~m}$ (MSL) toward the shoreline where the operator ends the line when turning the vessel around in a water depth of approximately $1 \mathrm{~m}$.

When possible the bathymetry data are combined with topographic surveys, extending the crossshore profiles landward to the dune fields. Topographic cross-shore beach profiles are collected by walking with an RTK DGPS receiver and antenna mounted to a backpack or by extracting the profiles from topographic beach surface maps surveyed with the CLAMMER.

\subsubsection{Horizontal and Vertical Accuracy}

The survey-grade GPS equipment accuracy is discussed in section 2.3.3. While the horizontal uncertainty of individual data points is approximately $0.05 \mathrm{~m}$, the CPSII operators cannot stay "on line," in waves and currents, to this level of accuracy. Typically, mean offsets are less than $2.0 \mathrm{~m}$ from the preprogrammed track lines and maximum offsets along the approximately $2 \mathrm{~km}$ long transects are typically less than $10.0 \mathrm{~m}$. While repeatability tests and merges with topographic data collected with the CLAMMER or a backpack suggest sub-decimeter vertical accuracy (Figures 9 and 10), significant variability in seawater temperature ( $\sim 10$ degrees Celsius) can affect depth estimates by as much as $20 \mathrm{~cm}$ in $12 \mathrm{~m}$ of water. However, water temperatures within the CRLC usually remain within a few degrees of the temperature associated with the present sound velocity. Therefore, a conservative estimate of the total vertical uncertainty for these nearshore bathymetry measurements is approximately $15 \mathrm{~cm}$. 

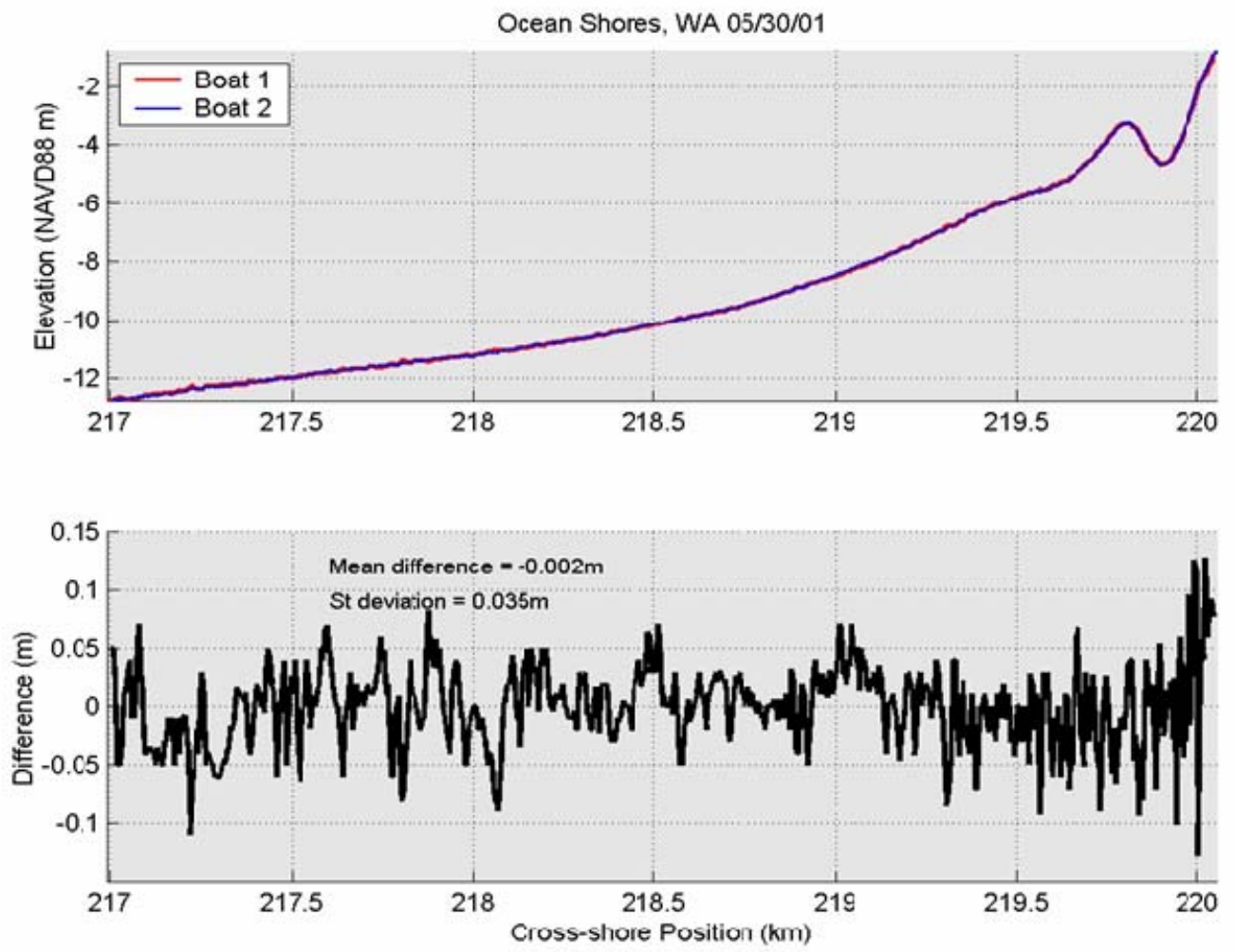

Figure 9. Repeatability comparison between a (smoothed) cross-shore profile surveyed with two different boats. 


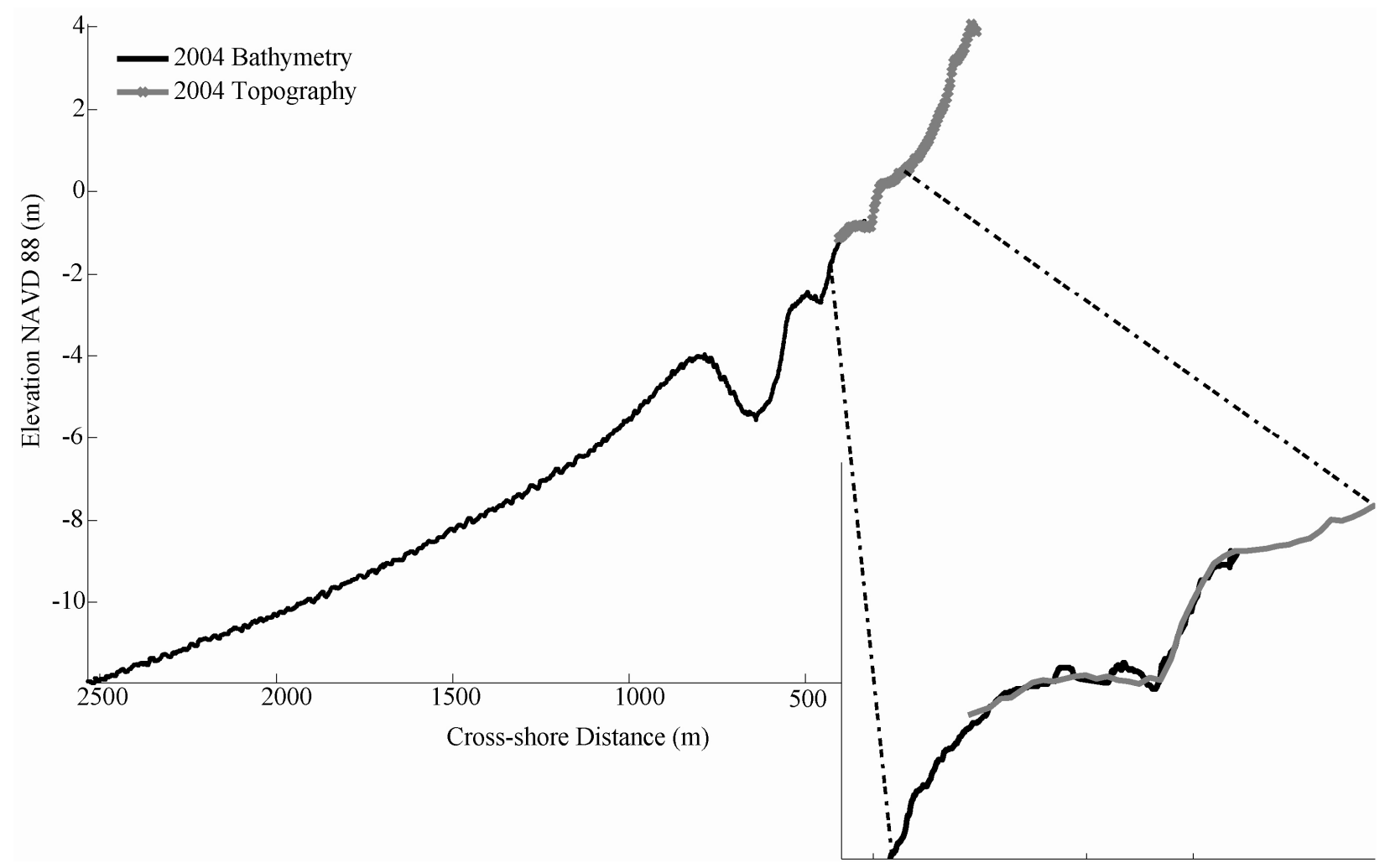

Figure 10. Merge between bathymetric and topographic data collected along a profile.

\subsubsection{Data Processing}

The following data processing steps are performed on each individual data file:

1. Outlier/Bad GPS Elimination: Each profile is examined, typically using a Perl script, to detect and remove any data points collected when the GPS receiver is not initialized in kinematic mode. Earlier versions of HYPACK store data regardless of GPS quality and therefore the raw data files may contain non-precise data. However, HYPACK does record a GPS data quality string so the Perl script eliminates any data without the appropriate string value. This script also eliminates any obvious outliers from the raw files that are either shallower than the echo sounder blanking interval or deeper than a user defined cutoff value. 
2. HYPACK editing: Each profile is viewed using HYPACK's editor. Outliers that were not eliminated in the first step are removed by highlighting the point and deleting it from the record.

3. Export: Individual files (representing a single profile) are exported from Hypack as Easting, Northing, Elevation triplets in ASCII format.

4. Offset Corrections: Detailed laboratory and field tests (bar check) comparing the two echo sounders from Jose and Josb revealed a constant offset of approximately $15 \mathrm{~cm}$. The echo sounder on Josb was accurate to approximately $2 \mathrm{~cm}$ and the echo sounder on Jose consistently measured $15 \mathrm{~cm}$ deeper. Throughout the 2001 field campaign the two boats' instruments were compared by having each boat collect at least one duplicate profile per data collection session. This check also consistently showed the $15 \mathrm{~cm}$ offset between the two boats. To compensate for this offset, a $15 \mathrm{~cm}$ correction was added to the vertical coordinate of all the data collected using the echo sounder of Jose (1999, 2000, 2001, 2002 and 2003 profiles). These files, which have been run through Perl script, the HYPACK editor, and corrected for offsets, are considered the 'raw' data files. They are included in directories such as: |nearshore_bathymetry|data_00|NorthBeach|output_raw|.

5. Speed of Sound/Salinity Corrections: Since the echo sounders did not directly measure water temperature and therefore did not correct the speed of sound in water in real time, all data have been corrected to adjust the vertical coordinate for the actual speed of sound based on water temperatures measured by local wave buoys. Further, no measurements of salinity were made or were available from local buoys. A sensitivity analysis was performed to investigate the effect of salinity and temperature on depth measurements through speed of sound adjustment on a profile. The results show that a normal range of water temperature can have a measurable effect on depth readings. The worst possible inducement of error, when the water temperature estimate is approximately $10^{\circ} \mathrm{C}$ different from the actual water temperature, results in approximately $0.20 \mathrm{~m}$ of vertical change at a water depth of $11 \mathrm{~m}$. Therefore, the temperature chosen to correct the 
bathymetric measurements for each profile is taken as the average of the surface water temperatures recorded at the wave buoy closest to the data collection site during the corresponding survey period (Tables $7-14$ ). Two standard deviations of all water temperature estimates (over 90 samples in four years) is less than three degrees Celsius. Therefore, the majority of nearshore bathymetric profiles have been vertically adjusted for temperature by less than $10 \mathrm{~cm}$.

The salinity is fixed at 31 psu for all lines as its small variations in the sampling region (Gelfenbaum et al., 2000) had a negligible effect when performing a speed of sound correction to the data.

6. Smoothing: A smoothing operation was performed using a median filter on the $\mathrm{z}$ coordinate in the $\mathrm{x}$-direction to reduce high frequency fluctuations. Varying window sizes were used to obtain a smooth profile while maintaining the integrity of the actual data points. These files, which have been run through a customized Perl script, the HYPACK editor, corrected for offsets, speed of sound and salinity, and smoothed are considered as the 'processed' data files. They are located in the \nearshore_bathymetryldata_00। NorthBeachloutput_fin $\mid$ folder.

\subsubsection{Regional nearshore monitoring, 2004-present}

During the summer of 2004, a third generation Coastal Profiling System (hereinafter referred to as CPSIII, Figure 11) was designed, built, and implemented for sampling in the CRLC. This new system continued with the sampling scheme described in Section 2.7.2. 


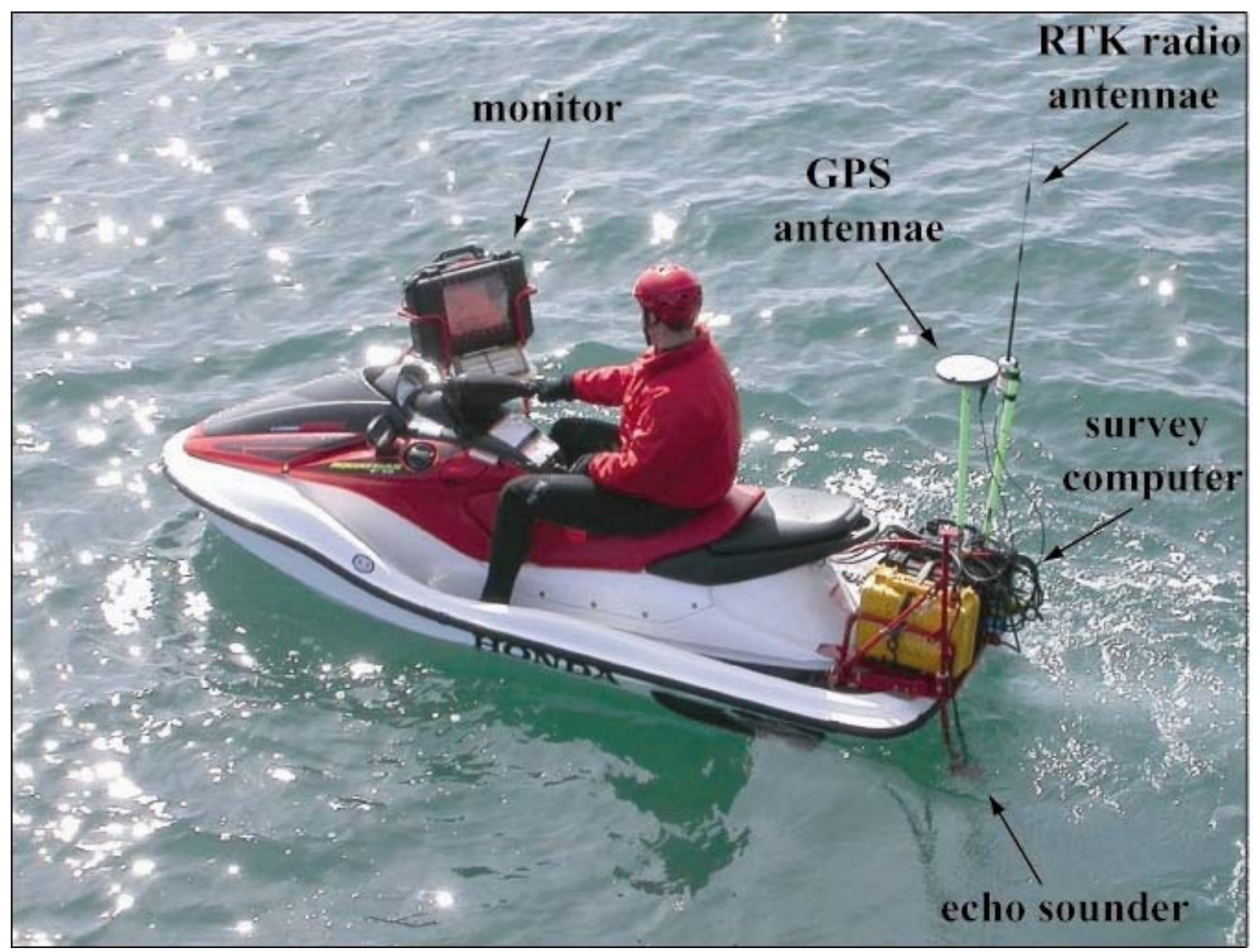

Figure 11. Third generation Coastal Profiling System (CPSIII) in action.

\subsubsection{Field Equipment: Third Generation Coastal Profiling System}

The CPSIII has a similar physical setup as the CPSII, but is mounted on a newer PWC model and includes updated hardware.

The modifications for the third generation system are discussed below. The PWC used for the CPSIII is a 2003 Honda Aquatrax F-12, which was chosen because it has a four-stroke engine and improved stability over the CPSII. This 3-person PWC measures $3.20 \mathrm{~m}$ in length, $1.25 \mathrm{~m}$ in width, and $1.06 \mathrm{~m}$ in height. The CPSII no longer contains a DC-DC converter and inline fuse in the storage space under the rear seat of the PWC. The GPS receiver setup has been incorporated into the water tight Pelican cases mounted on the stern of the vessel. The CPSIII system draws 
approximately 24 volts at approximately 2.8 amps. The GPS antenna is located approximately $120 \mathrm{~cm}$ directly above the echo sounder transducer.

The echo sounder is an ESE-50 single frequency echo sounder with a $200 \mathrm{kHz}$ transducer manufactured by Flash Fire Technology, Inc. This echo sounder has adjustable gains, offset, and serial outputs. One limitation of the new system is that the speed of sound is set at $1500 \mathrm{~m} / \mathrm{s}$ and cannot be adjusted to compensate for varying conditions. The echo sounder transducer is mounted on a removable and adjustable arm at the stern of the vessel. This adjustable arm allows the PWC operator to raise the echo sounder during vessel deployment and recovery and helps to avoid potential damage to the echo sounder in very shallow water. The Palmax Pen Computer from the CPSII system was replaced by a Big Bay Technologies P3 mini PC. The monitor was replaced with a 12 inch Big Bay Technologies outdoor high bright display monitor, which eliminates the need for the retractable bellows.

\subsubsection{Field Procedures}

These have not changed from the CPSII (see section 2.7.2.2 Field Procedures).

\subsubsection{Horizontal and Vertical Accuracy}

These have not changed from the CPSII (see section 2.7.2.3 Field Procedures).

\subsubsection{Data Processing}

Modifications to Data Processing for the CPSIII system are discussed below.

1. Outlier/Bad GPS Elimination: The updated version of HYPACK software (Hypack Max) can be set to store only data collected when the GPS receiver is initialized in real time kinematic mode, so the PERL script is not needed to eliminate data that does not meet this specification. However, the PERL script is still used to eliminate any obvious outliers from the raw files that are either shallower than the echo sounder blanking interval or deeper than a user defined cutoff value.

2. Offset Corrections: There is no longer a consistent offset recorded between the echo sounder of Boat 1 and Boat 2, therefore no offset correction is applied. 


\section{DATA COLLECTED}

Many components of the monitoring program are collected at different sampling frequencies.

Table 4 provides a description of the seasonal variability in sampling for several components.

Table 4. GPS data collected.

\begin{tabular}{|c|c|c|c|c|c|}
\hline $\begin{array}{c}\text { Field } \\
\text { Campaign }\end{array}$ & $\begin{array}{l}\text { Geodetic } \\
\text { Control }\end{array}$ & $\begin{array}{c}\text { Topographic } \\
\text { Beach } \\
\text { Profiles }\end{array}$ & $\begin{array}{c}\text { Topographic } \\
\text { Surface } \\
\text { Maps }\end{array}$ & $\begin{array}{c}\text { Nearshore } \\
\text { Bathymetric } \\
\text { Profiles }\end{array}$ & $\begin{array}{c}\text { Sediment } \\
\text { Samples }\end{array}$ \\
\hline Summer 1997 & $\mathrm{x}$ & $x$ & $\mathrm{x}$ & --- & $x$ \\
\hline Fall 1997 & --- & --- & --- & --- & --- \\
\hline Winter 1998 & --- & $x$ & $x$ & --- & $x$ \\
\hline Spring 1998 & --- & --- & --- & --- & --- \\
\hline Summer 1998 & --- & $x$ & $x$ & $x$ & $x$ \\
\hline Fall 1998 & --- & $x$ & --- & --- & --- \\
\hline Winter 1999 & --- & $x$ & $x$ & --- & --- \\
\hline Spring 1999 & --- & $\mathrm{x}$ & --- & --- & --- \\
\hline Summer 1999 & $x$ & $x$ & $x$ & $x$ & $x$ \\
\hline Fall 1999 & --- & $x$ & --- & --- & --- \\
\hline Winter 2000 & --- & $x$ & $x$ & --- & --- \\
\hline Spring 2000 & --- & $x$ & --- & --- & --- \\
\hline Summer 2000 & --- & $x$ & $x$ & $x$ & $x$ \\
\hline Fall 2000 & --- & $x$ & --- & --- & --- \\
\hline Winter 2001 & --- & $x$ & $x$ & --- & --- \\
\hline Spring 2001 & --- & $x$ & --- & --- & --- \\
\hline Summer 2001 & --- & $x$ & $x$ & $\mathrm{x}$ & $x$ \\
\hline Fall 2001 & --- & $x$ & --- & --- & --- \\
\hline Winter 2002 & --- & $x$ & $x$ & --- & --- \\
\hline Spring 2002 & --- & $x$ & --- & --- & --- \\
\hline Summer 2002 & --- & $x$ & $x$ & $x$ & $x$ \\
\hline Fall 2002 & --- & $x$ & --- & --- & --- \\
\hline Winter 2003 & --- & $x$ & $x$ & --- & --- \\
\hline Spring 2003 & --- & $x$ & --- & --- & --- \\
\hline Summer 2003 & --- & $x$ & $x$ & $x$ & $x$ \\
\hline Fall 2003 & --- & $\mathrm{x}$ & --- & --- & --- \\
\hline Winter 2004 & --- & $x$ & $x$ & --- & --- \\
\hline Spring 2004 & --- & $x$ & --- & --- & --- \\
\hline Summer 2004 & --- & $x$ & $x$ & $x$ & $x$ \\
\hline Fall 2004 & --- & $x$ & --- & --- & --- \\
\hline Winter 2005 & --- & $x$ & $x$ & --- & --- \\
\hline Spring 2005 & --- & $x$ & --- & --- & --- \\
\hline Summer 2005 & --- & $\mathrm{x}$ & $\mathrm{x}$ & $\mathrm{x}$ & $\mathrm{x}$ \\
\hline Fall 2005 & --- & $\mathrm{x}$ & --- & --- & --- \\
\hline
\end{tabular}




\subsection{Waves and Water Levels}

The CRLC is well known for the severity of its wave climate (Tillotsen and Komar, 1997; Allan and Komar, 2000; Allan and Komar, 2002) with deep-water significant wave heights and periods having annual averages of $2.2 \mathrm{~m}$ and $10.4 \mathrm{~s}$ respectively, but with winter storms generating significant wave heights of up to $14 \mathrm{~m}$. High long-period waves (averaging approximately $3 \mathrm{~m}$ in height and $12-13$ s periods), high water levels, and a west-southwest direction of wave approach characterize the winter months (November through February) along the CRLC, while smaller waves and shorter periods (1.2 $\mathrm{m}$ and $8 \mathrm{~s})$, lower water levels, and wind and waves from the west-northwest are the typical summer (May through August) conditions (Figure 12). The seasonal cycle in waves and water levels along the CRLC (Figure 12) results in a seasonal morphodynamic cycle. Offshore and northerly sediment transport results in beach erosion during the winter and onshore and southerly sediment transport dominates beach recovery in the summer months. Tides throughout the CRLC are mixed semi-diurnal with a 2 - $4 \mathrm{~m}$ tide range. Water levels also have a distinct seasonal cycle measuring approximately $15 \mathrm{~cm}$ higher in the winter than during summer months (Figure 12) (NOAA Station \# 9440910, CDIP Station \# 036).

In the Pacific Northwest, strong El Niños feature increased frequency of storm tracks from the south-southwest and higher than normal sea levels (Komar, 1986; Kaminsky et al., 1998; Komar et al., 2000). Interannual climatic variability also affects waves and water levels, which in turn can influence beach responses. During the strong El Niño of 1982/1983, large wave heights and acute southerly wave angles forced an increased magnitude of northerly offshore sand transport in Oregon during the winter, causing severe beach erosion and changes in shoreline orientation that persisted for several years (Peterson et al., 1990). Unfortunately, the magnitude of beach change during that El Niño was not recorded by detailed surveys. The winter of 1997/1998, the first winter of the monitoring program, coincided with one of the strongest El Niño events on record for the Pacific Northwest (Komar et al., 2000). During that El Niño the CRLC experienced monthly mean water levels up to $0.4 \mathrm{~m}$ higher than typical (Figure 12), mean winter wave heights up to $1.0 \mathrm{~m}$ higher than usual, and wave directions having a more SW approach (Kaminsky et al., 1998). These changes in environmental conditions had a distinct effect on CRLC beaches. 

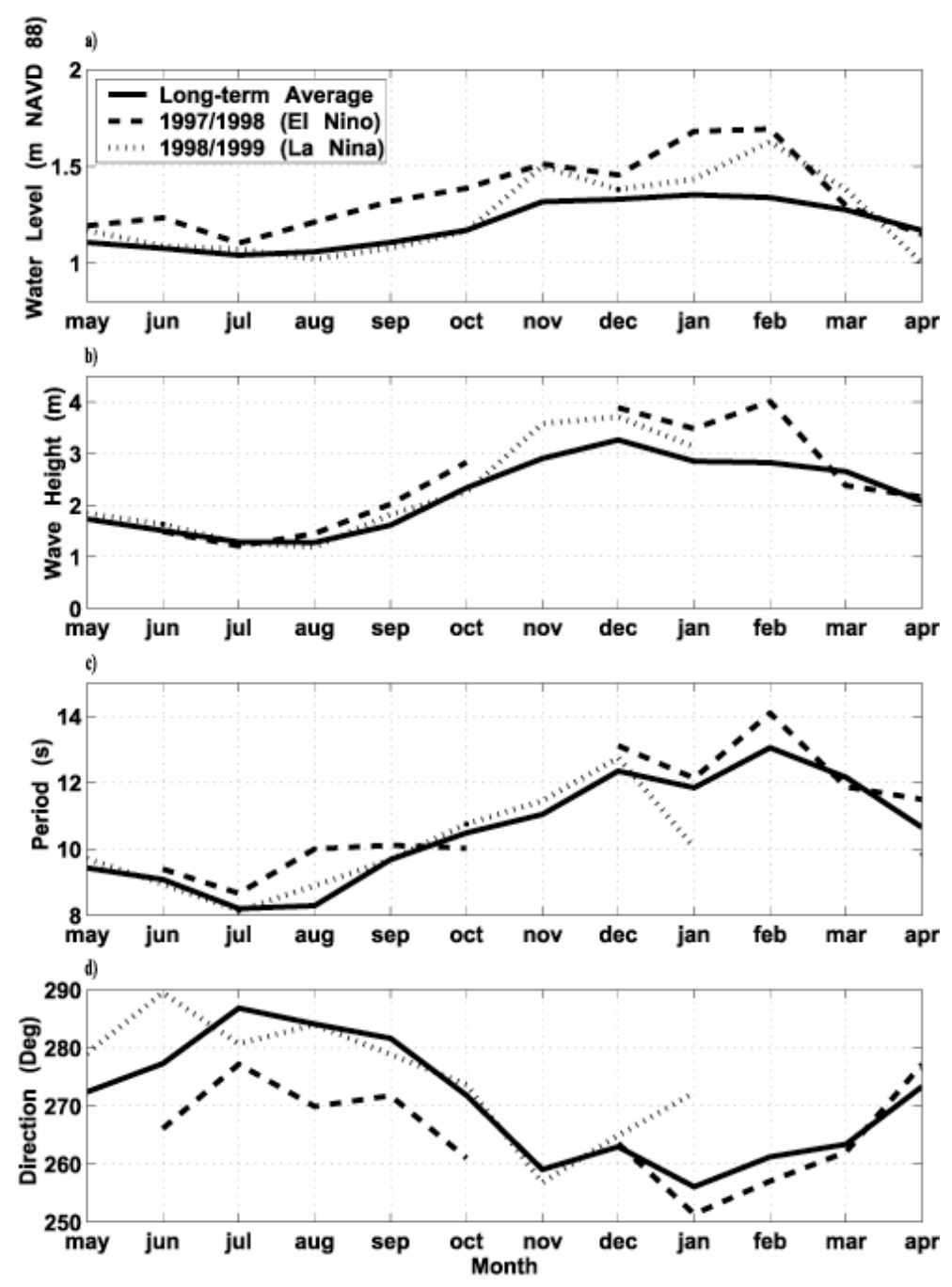

Figure 12. Monthly means a) water levels measured at the NOS Toke Point tide gage in Willapa Bay, b) significant wave height, c) period, and d) direction from the Grays Harbor CDIP buoy. The solid line represents long-term means beginning in 1980 for water levels, 1981 for wave heights and periods and 1993 for wave direction. The 1997/1998 El Niño (dash line) and the 1998/1999 La Niña (short dashed) are also shown.

\subsection{Geodetic Control}

The Washington Coastal Geodetic Control Network consists of 96 stations, the locations of which are described in Table 5. Thirteen of these stations were created by the Coastal Monitoring Program while others already existed and were included in the network. In the summers of 1997 and 1999, geodetic control surveying campaigns were conducted to create new stations and ensure the accuracy of existing stations. 


\subsubsection{Data Coverage}

Table 5. Coordinates for the stations contained within the Washington Coastal Geodetic Control Network in the Washington State Plane, South, meters, NAD 83 and NAVD 88 coordinate systems.

\begin{tabular}{|c|c|c|c|c|c|c|c|}
\hline \multirow{2}{*}{$\begin{array}{l}\text { Station } \\
\text { Number }\end{array}$} & \multirow[t]{2}{*}{ County } & \multirow{2}{*}{$\begin{array}{l}\text { NGS } \\
\text { PID }\end{array}$} & \multirow[t]{2}{*}{ Station Designation } & \multirow{2}{*}{$\begin{array}{c}\text { Station } \\
\text { Type }\end{array}$} & \multicolumn{2}{|c|}{ NAD 83 (1991) } & \multirow{2}{*}{$\begin{array}{c}\text { NAVD } 88 \\
\text { Elevation } \\
(\mathrm{m})\end{array}$} \\
\hline & & & & & Easting (m) & Northing (m) & \\
\hline 01 & Grays Harbor & SD0794 & GRENVILLE & Local & 214355.081 & 225915.358 & 37.63 \\
\hline 02 & Grays Harbor & SD0132 & SOUTH & Secondary & 216603.847 & 225290.033 & 4.643 \\
\hline 03 & Grays Harbor & SD0129 & L 443 & Local & 217632.452 & 223555.901 & 6.86 \\
\hline 04 & Grays Harbor & SD0780 & PIER RM 1 AZ MK & Local & 218706.174 & 218480.556 & 7.13 \\
\hline 05 & Grays Harbor & SY5644 & HATCHERY & Primary & 236150.840 & 216822.073 & 36.537 \\
\hline 06 & Grays Harbor & AH6996 & GKAM & Local & 219509.529 & 214862.915 & 7.16 \\
\hline 07 & Grays Harbor & SD0117 & R 443 & Secondary & 225227.546 & 212765.386 & 32.988 \\
\hline 08 & Grays Harbor & AH6997 & BHUX & Local & 220002.033 & 211327.432 & 5.96 \\
\hline 09 & Grays Harbor & AH6998 & GP 14109-31 & Local & 220961.222 & 204470.295 & 7.34 \\
\hline 10 & Grays Harbor & AH6999 & DIANA & Local & 221227.901 & 199520.997 & 6.01 \\
\hline 11 & Grays Harbor & SD0720 & MOTULIPS & Secondary & 232060.108 & 198880.826 & 15.49 \\
\hline 12 & Grays Harbor & AH7000 & DAMONS & Local & 221436.304 & 193625.612 & 5.55 \\
\hline 13 & Grays Harbor & AH7001 & ET & Local & 221016.816 & 191040.669 & 8.55 \\
\hline 14 & Grays Harbor & AH7002 & BUTTER & Local & 220765.202 & 187608.277 & 5.50 \\
\hline 15 & Grays Harbor & $\mathrm{SC} 2824$ & CENTRAL & Primary & 256336.103 & 187168.504 & 38.31 \\
\hline 16 & Grays Harbor & AH6993 & OMEN & Secondary & 225495.170 & 185461.276 & 4.59 \\
\hline 17 & Grays Harbor & AH7003 & $\begin{array}{l}\text { NERR NERR } \\
\text { (Destroyed) }\end{array}$ & Local & 221682.225 & 184240.742 & 7.42 \\
\hline 18 & Grays Harbor & AH7004 & X 1 & Local & 220427.159 & 183793.925 & 7.10 \\
\hline 19 & Grays Harbor & SD0042 & 9441102 TIDAL 2 & Local & 224937.418 & 181306.423 & 4.652 \\
\hline 20 & Grays Harbor & AH7005 & HD 1 & Local & 223445.898 & 180809.016 & 8.04 \\
\hline 21 & Grays Harbor & SD0394 & $\begin{array}{c}\text { GRAYS HARBOR E } \\
\text { BASE } 2\end{array}$ & Secondary & 225837.656 & 180705.800 & 5.06 \\
\hline 22 & Grays Harbor & AH7006 & WORM & Local & 223748.246 & 179169.649 & 9.90 \\
\hline 23 & Grays Harbor & AH7007 & SPICE & Local & 224091.455 & 177805.208 & 10.93 \\
\hline 24 & Grays Harbor & SD0020 & GUNVILLE & Secondary & 227653.074 & 176052.922 & 4.934 \\
\hline 25 & Grays Harbor & AH7008 & RDAN & Local & 224751.964 & 174824.006 & 6.05 \\
\hline 26 & Grays Harbor & AH7009 & PRUG & Local & 225147.769 & 171889.637 & 8.33 \\
\hline 27 & Pacific & AH7010 & PC 068 & Local & 225461.984 & 168616.114 & 7.80 \\
\hline 28 & Pacific & SD0453 & PC 064 & Local & 225502.985 & 165743.021 & 8.14 \\
\hline 30 & Pacific & AH7011 & GELF & Local & 225512.109 & 163324.692 & 5.74 \\
\hline 31 & Pacific & AH7012 & CSW 2 & Local & 228200.073 & 161801.350 & 91.40 \\
\hline 29 & Pacific & AH6994 & CSW 1 & Secondary & 228207.248 & 161750.215 & 96.91 \\
\hline 32 & Pacific & AH7013 & GP 25105-13 & Local & 229654.821 & 161131.872 & 4.33 \\
\hline 33 & Pacific & SC0916 & FLAG & Local & 234674.370 & 158293.909 & 4.095 \\
\hline 34 & Pacific & SC2806 & SOUTH BEND & Primary & 246765.528 & 153108.439 & 25.193 \\
\hline 35 & Pacific & AH7014 & LB 1 & Local & 227437.439 & 152509.793 & 3.88 \\
\hline 36 & Pacific & AH7015 & PC 055 RM2 & Local & 227077.024 & 150868.728 & 4.58 \\
\hline 37 & Pacific & SD0533 & PC 051 & Local & 226884.585 & 148626.156 & 8.69 \\
\hline 38 & Pacific & AH6995 & BONE & Secondary & 237206.298 & 148161.257 & 3.76 \\
\hline 39 & Pacific & SD0358 & MESS & Local & 229982.397 & 144909.939 & 4.209 \\
\hline 40 & Pacific & AH7016 & PC 044 & Local & 227016.756 & 144587.456 & 7.26 \\
\hline 41 & Pacific & AH7017 & PC 057 & Local & 227065.847 & 142639.147 & 7.76 \\
\hline 42 & Pacific & AH7018 & GOULTER 3 & Local & 229766.295 & 141522.662 & 4.63 \\
\hline 43 & Pacific & SD0531 & OYSTER 3 & Local & 227103.068 & 141090.565 & 8.29 \\
\hline 44 & Pacific & AH7019 & PC 037 & Local & 227115.905 & 138871.463 & 9.79 \\
\hline
\end{tabular}




\begin{tabular}{|c|c|c|c|c|c|c|c|}
\hline 45 & Pacific & AH7020 & PC 035 & Local & 227095.614 & 137662.732 & 9.76 \\
\hline 46 & Pacific & SD0323 & X 537 & Secondary & 227176.554 & 137586.974 & 5.763 \\
\hline 47 & Pacific & AH7021 & PC 032 & Local & 227056.809 & 135788.931 & 9.67 \\
\hline 48 & Pacific & SD0554 & COTTA & Local & 228989.637 & 135555.140 & 2.80 \\
\hline 49 & Pacific & SD0560 & KLIPSAN 2 & Local & 226941.030 & 131888.571 & 8.85 \\
\hline 50 & Pacific & AH7022 & PC 021 & Local & 226778.994 & 128970.830 & 8.69 \\
\hline 51 & Pacific & SD0538 & SNAKE 2 & Local & 229550.786 & 128681.474 & 3.03 \\
\hline 52 & Pacific & SC1020 & M 536 & Secondary & 238304.176 & 127434.240 & 7.789 \\
\hline 53 & Pacific & SD0563 & RICH & Local & 226581.743 & 126285.947 & 7.48 \\
\hline 54 & Pacific & SD0536 & LIME 2 & Local & 229630.549 & 125706.828 & 3.32 \\
\hline 55 & Pacific & AH7023 & PC 014 & Local & 226345.349 & 123150.053 & 7.40 \\
\hline 56 & Pacific & AH7024 & PC 008 & Local & 225822.964 & 118601.072 & 7.42 \\
\hline 57 & Pacific & AH7025 & PC 025 & Local & 225473.758 & 116431.952 & 6.32 \\
\hline 58 & Pacific & SD0287 & TURN RM 4 & Local & 226897.696 & 116248.932 & 5.376 \\
\hline 59 & Wahkiakum & SC2756 & GP 35004-3 & Primary & 257618.624 & 116055.406 & 27.89 \\
\hline 60 & Pacific & AH7026 & PC 004 & Local & 225210.806 & 115181.161 & 7.23 \\
\hline 61 & Pacific & SD0854 & NORTH HEAD RM 4 & Secondary & 224613.617 & 113727.382 & 77.69 \\
\hline 62 & Pacific & SD0090 & MCKENZIE HEAD & $\mathrm{n} / \mathrm{a}$ & $\begin{array}{l}\text { Bad GPS } \\
\text { Visibility }\end{array}$ & & \\
\hline 77 & Pacific & AH7027 & $\begin{array}{c}\text { MCKENZIE HEAD } \\
\text { RM } 3\end{array}$ & Local & 225330.915 & 111871.682 & 58.99 \\
\hline 63 & Pacific & SD0640 & BETTY M & Local & 227089.549 & 110920.242 & 6.55 \\
\hline 64 & Pacific & SD0299 & 9440574 A TIDAL & Local & 224638.597 & 110670.308 & 4.872 \\
\hline 65 & Clatsop & SD0651 & EAST JETTY 2 & Local & 229432.797 & 105168.514 & 9.8 \\
\hline 66 & Clatsop & AB2106 & SMUR* & Secondary & 233158.444 & 102901.091 & 7.6 \\
\hline 67 & Clatsop & SC2198 & MIT & Local & 232150.030 & 100432.955 & 28.7 \\
\hline 68 & Clatsop & AH7028 & IREDALE (Destroyed) & Local & 231520.392 & 99783.876 & 8.3 \\
\hline 78 & Clatsop & AH8187 & IREDALE RESET & Local & 231520.396 & 99783.896 & 8.6 \\
\hline 69 & Clatsop & AH7029 & KIM & Local & 233109.080 & 96639.806 & 28.3 \\
\hline 70 & Clatsop & SC0554 & UU $282 *$ & Secondary & 239326.392 & 95561.858 & 4.4 \\
\hline 71 & Clatsop & AH7030 & RILEA & Local & 233676.170 & 92569.623 & 13.0 \\
\hline 72 & Clatsop & SC1033 & X 711* & Local & 235757.129 & 88256.226 & 9.6 \\
\hline 73 & Clatsop & AH7031 & DELRAY & Local & 234763.667 & 85204.106 & 11.5 \\
\hline 74 & Clatsop & SC0617 & MEADOW RESET* & Secondary & 235240.572 & 82967.391 & 11.7 \\
\hline 75 & Clatsop & RD1141 & SEASIDE RM 2* & Local & 234404.488 & 79328.263 & 7.2 \\
\hline 76 & Clatsop & RD4216 & CANN & Primary & 231371.929 & 64617.918 & 30.5 \\
\hline 79 & Pacific & SD0297 & 9440574 C TIDAL & Local & 225226.997 & 111061.382 & 4.678 \\
\hline 80 & Grays Harbor & & X 1 RM 1 & Local & 220440.491 & 183959.508 & 5.66 \\
\hline 81 & Grays Harbor & & NERR 2 & Local & 222313.201 & 185939.810 & 4.29 \\
\hline 90 & Clatsop & & ASTOR (a.k.a. ASTO) & Local & 238953.073 & 97089.346 & 3.02 \\
\hline 91 & Pacific & & BC TIDAL & Local & 236074.214 & 149158.719 & 4.23 \\
\hline 92 & Pacific & & NC TIDAL & Local & 229622.823 & 135895.987 & 6.01 \\
\hline 93 & Pacific & & NR TIDAL & Local & 238296.162 & 127535.464 & 2.96 \\
\hline 94 & Pacific & & SB TIDAL & Local & 246578.968 & 153728.636 & 4.33 \\
\hline 95 & Pacific & SC0980 & Т 540 & Local & 240118.114 & 138893.909 & 31.47 \\
\hline 96 & Lacey & & PARK & Special & 324710.351 & 192957.682 & 49.78 \\
\hline
\end{tabular}




\subsection{Beach Profiles}

The Coastal Monitoring Program has collected over fifteen hundred beach profiles since the field program began in 1997. The following sections discuss the breadth of data coverage, and issues concerning data quality.

\subsubsection{Data Coverage}

Starting in summer 1997, profiles were collected bi-annually, but since fall 1998 they have been collected quarterly. Summer surveys are conducted in late August and September, fall surveys in November and December, winter surveys in February and March, and spring surveys are performed in June. It typically takes 10 spring low tides (approximately five full days) to complete the 49 profiles, however, there can be several weeks separating profile collection dates within a single surveying campaign. Shoreline armoring and a beach nourishment project significantly changed the beach environment at CSW and poor GPS satellite visibility at the E2 led to elimination of these two profiles from the survey program in 1999. Two new sites (CASINO and JACKSON), in areas where increased monitoring was warranted, replaced these locations. Table 2 lists the locations of each of the 49 profiles that have been surveyed from 1997 to 2005 .

While not as accurate as standard terrestrial surveying using a rod and level, walking the profiles with a GPS backpack is justified by both the reduction in survey time and the large seasonal changes observed on the high-energy beaches of the CRLC (Figure 13a). Datum-based shorelines are extracted from the beach profiles to investigate seasonal to interannual beach change (Figure 13b). Along the CRLC the 3.0-m (NAVD88) contour position has been shown to most closely approximate proxy-based shorelines as derived from aerial photography and historical surveys such as the National Ocean Service T-sheets (Ruggiero et al., 2003a). Error bars on the position of the $3.0 \mathrm{~m}$ contour are calculated using the methodology described by Stockdon et al., 2002 for datum-based shorelines (Figure 13b). 
a)

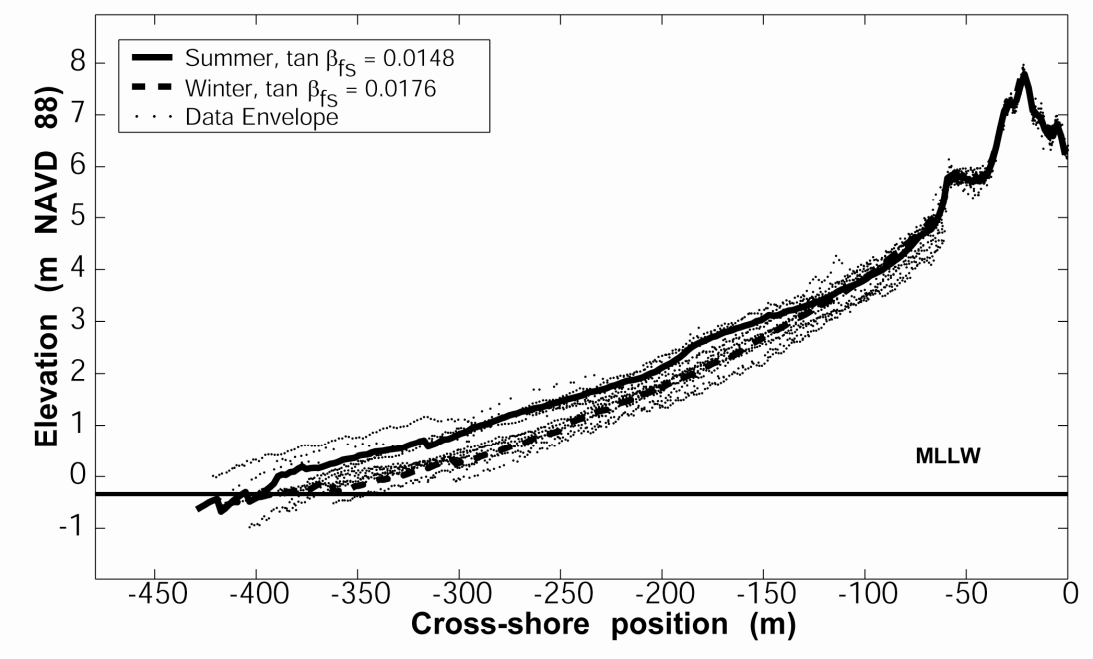

b)

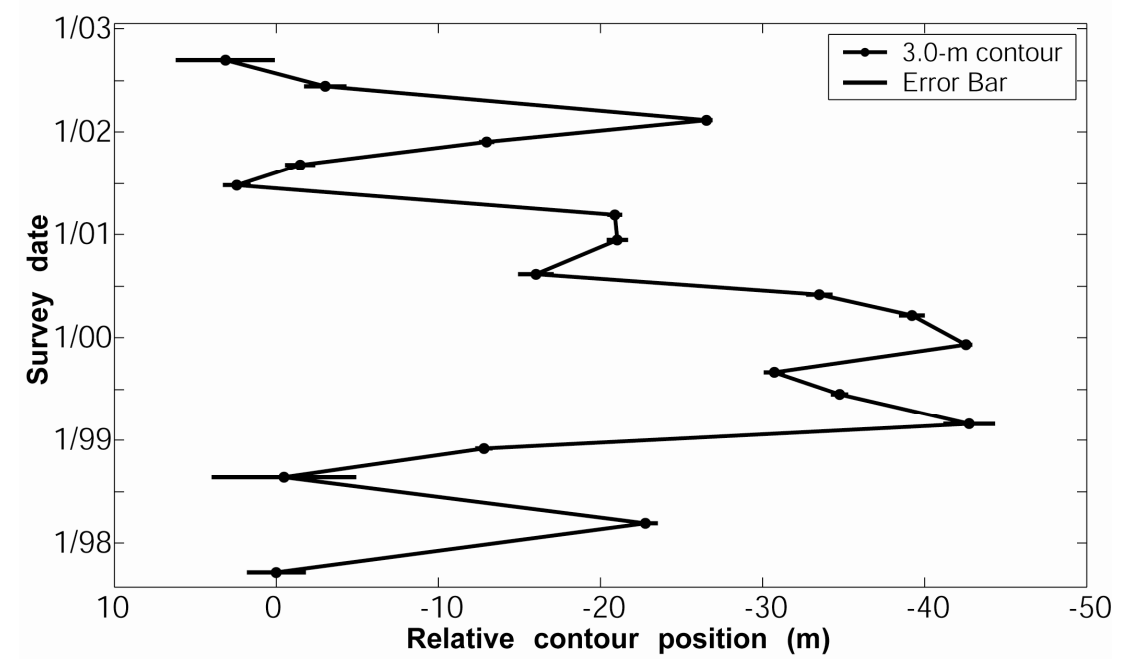

Figure 13. Seasonal changes a) observed along a cross-shore beach profile and, b) in a datumbased extracted shoreline in the CRLC.

\subsection{Sediment Size Distributions}

The Coastal Monitoring Program has collected and processed over 280 mid-beach surface sediment samples from 1997 to 2005.

\subsubsection{Data Coverage}

Due to a limited amount of processing time, the mid beach sediment samples are the only samples collected and processed consistently since the summer of 2002. Table 6 presents the coordinates for the mid-beach sample locations on each profile. 
Table 6. Coordinates for sediments surface sample locations.

\begin{tabular}{|c|c|c|c|c|c|c|}
\hline $\begin{array}{l}\text { PROFILE } \\
\text { NUMBER }\end{array}$ & $\begin{array}{l}\text { PROFILE } \\
\text { NAME }\end{array}$ & $\begin{array}{c}\text { BEACH } \\
\text { LOCATION }\end{array}$ & $\begin{array}{c}\text { NORTHING } \\
(\mathrm{m})\end{array}$ & $\begin{array}{l}\text { EASTING } \\
(\mathrm{m})\end{array}$ & $\begin{array}{c}\text { LATITUDE } \\
(\mathrm{N})\end{array}$ & $\begin{array}{l}\text { LONGITUDE } \\
\text { (W) }\end{array}$ \\
\hline 1 & E2 & Mid-Beach & 225784.50 & 214697.70 & 47.30318 & 124.2740727 \\
\hline 2 & SOUTH & Mid-Beach & 224955.20 & 216904.50 & 47.296675 & 124.244404 \\
\hline 3 & L443 & Mid-Beach & 222877.80 & 217749.20 & 47.27837 & 124.2319491 \\
\hline 4 & B1 & Mid-Beach & 221946.08 & 217981.20 & 47.270097 & 124.2283043 \\
\hline 5 & A1.5 & Mid-Beach & 220447.06 & 218278.70 & 47.256755 & 124.2234424 \\
\hline 6 & PIER RM1 & Mid-Beach & 218502.04 & 218664.01 & 47.239443 & 124.2171468 \\
\hline 7 & GKAM & Mid-Beach & 214972.65 & 219443.45 & 47.208061 & 124.2046751 \\
\hline 8 & BHUX & Mid-Beach & 211269.68 & 219982.67 & 47.175016 & 124.1952762 \\
\hline 9 & GP-14109 & Mid-Beach & 204506.90 & 220896.84 & 47.114634 & 124.1790701 \\
\hline 10 & DIANA & Mid-Beach & 199581.77 & 221214.77 & 47.070511 & 124.1718652 \\
\hline 11 & DAMONS & Mid-Beach & 193729.54 & 221181.36 & 47.01791 & 124.1687221 \\
\hline 12 & ET & Mid-Beach & 191000.72 & 221042.10 & 46.993331 & 124.1688829 \\
\hline 13 & BUTTER & Mid-Beach & 187598.47 & 220754.82 & 46.962638 & 124.170575 \\
\hline 14 & X1 NORTH & Mid-Beach & 184242.38 & 220380.98 & 46.932323 & 124.1734288 \\
\hline 15 & X1 SOUTH & Mid-Beach & 183946.08 & 220430.55 & 46.929682 & 124.1725975 \\
\hline 16 & HD-1 & Mid-Beach & 180648.70 & 223503.94 & 46.90133 & 124.1302886 \\
\hline 17 & WORM & Mid-Beach & 179096.15 & 223914.21 & 46.887548 & 124.1239736 \\
\hline 18 & SPICE & Mid-Beach & 177788.03 & 224098.37 & 46.875868 & 124.120772 \\
\hline 19 & RDAN & Mid-Beach & 174837.29 & 224737.73 & 46.849615 & 124.1106218 \\
\hline 20 & PRUG & Mid-Beach & 171888.75 & 225155.84 & 46.823289 & 124.1033795 \\
\hline 21 & PC068 & Mid-Beach & 168607.71 & 225461.75 & 46.793929 & 124.0974138 \\
\hline 22 & PC064 & Mid-Beach & 165742.80 & 225503.35 & 46.768199 & 124.0951596 \\
\hline 23 & GELF & Mid-Beach & 163299.62 & 225501.38 & 46.746242 & 124.0937284 \\
\hline 24 & CSW & Mid-Beach & 161117.44 & 228466.29 & 46.727838 & 124.0536785 \\
\hline 25 & LB1 & Mid-Beach & 152507.99 & 227436.34 & 46.650045 & 124.0620546 \\
\hline 26 & PC055 & Mid-Beach & 150869.71 & 227077.21 & 46.635175 & 124.0657744 \\
\hline 27 & PC051 & Mid-Beach & 148630.85 & 226894.65 & 46.61498 & 124.0668345 \\
\hline 28 & PC044 & Mid-Beach & 144588.01 & 227016.82 & 46.578695 & 124.0628577 \\
\hline 29 & PC057 & Mid-Beach & 142638.33 & 227066.07 & 46.561192 & 124.0610677 \\
\hline 30 & OYSTER3 & Mid-Beach & 141023.13 & 227101.57 & 46.54669 & 124.0596547 \\
\hline 31 & PC037 & Mid-Beach & 138870.83 & 227114.62 & 46.527352 & 124.0582191 \\
\hline 32 & PC035 & Mid-Beach & 137661.13 & 227094.63 & 46.516471 & 124.0577685 \\
\hline 33 & PC032 & Mid-Beach & 135789.31 & 227056.95 & 46.499633 & 124.0571593 \\
\hline 34 & KLIPSAN2 & Mid-Beach & 131890.57 & 226940.21 & 46.464545 & 124.0563892 \\
\hline 35 & PC021 & Mid-Beach & 128970.91 & 226777.85 & 46.438239 & 124.0567874 \\
\hline 36 & RICH & Mid-Beach & 126284.98 & 226594.30 & 46.414024 & 124.0575977 \\
\hline 37 & PC014 & Mid-Beach & 123150.18 & 226345.83 & 46.385749 & 124.0589871 \\
\hline 38 & РC008 & Mid-Beach & 118598.87 & 225819.85 & 46.344629 & 124.0631464 \\
\hline 39 & PC025 & Mid-Beach & 116433.47 & 225474.97 & 46.325027 & 124.0663507 \\
\hline 40 & PC004 & Mid-Beach & 115182.56 & 225211.80 & 46.313677 & 124.0690301 \\
\hline 41 & CANBY & Mid-Beach & 112242.20 & 224488.27 & 46.286955 & 124.0766841 \\
\hline 42 & EASTJETTY2 & Mid-Beach & 104717.31 & 229459.65 & 46.22133 & 124.0078901 \\
\hline 43 & IREDALE & Mid-Beach & 99886.90 & 231467.36 & 46.178714 & 123.9791308 \\
\hline 44 & KIM & Mid-Beach & 96632.44 & 232633.04 & 46.149923 & 123.962198 \\
\hline 45 & RILEA & Mid-Beach & 92557.89 & 233693.27 & 46.113717 & 123.9461826 \\
\hline 46 & DELRAY & Mid-Beach & 85352.77 & 234803.45 & 46.049389 & 123.9277849 \\
\hline 47 & SEASIDERM2 & Mid-Beach & 80086.18 & 234619.88 & 46.001978 & 123.9271987 \\
\hline 48 & CASINO & Mid-Beach & 196607.68 & 220723.02 & 47.043581 & 124.176508 \\
\hline 49 & JACKSON & Mid-Beach & 120901.04 & 225694.13 & 46.365269 & 124.066130 \\
\hline
\end{tabular}




\subsection{Three Dimensional Beach Surface Maps}

The Coastal Monitoring Program has collected over 300 three-dimensional beach surface maps between 1997 and 2005. The following section describes the data collected.

\subsubsection{Data Coverage}

The non-uniformly spaced raw data (typically 5,000 to 10,000 points per survey) are mapped onto a uniform 2-dimensional gridded surface (10 m X $20 \mathrm{~m})$, permitting comparisons with subsequent surveys (Figure 14c). Once the CLAMMER data are gridded onto a surface (Figure 14d), datum-based shorelines (contour lines) can be extracted (Figure 14b).
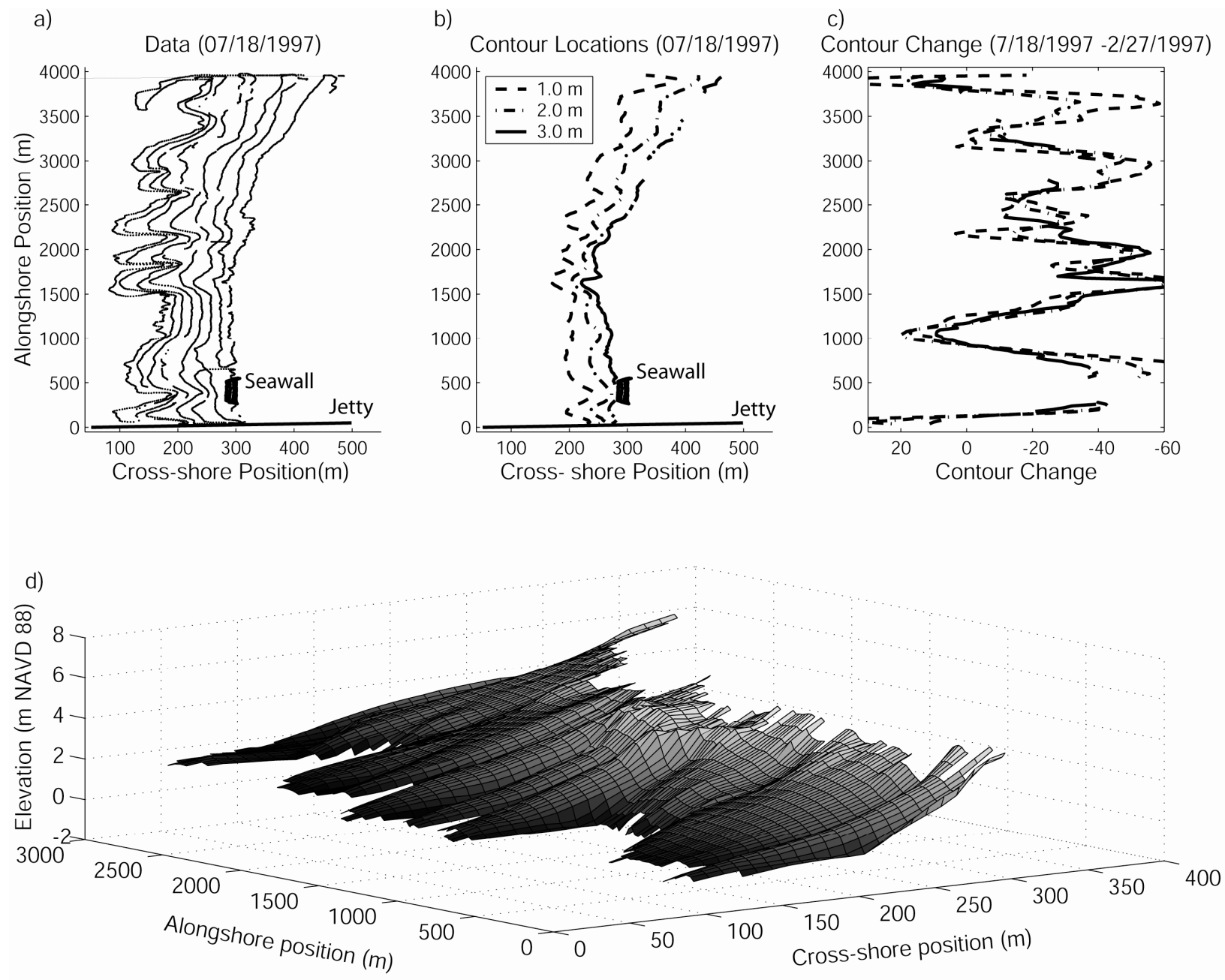

Figure 14. Surface map data is used to a) generate contour maps, b) extract contour locations, c) and compare contour change over time, d) by creating a 2-dimensional gridded surface from raw data points. 


\subsection{Shoreline Reference Feature Mapping}

The Coastal Monitoring Program has surveyed approximately 30 shoreline reference features from 1997-2005.

\subsubsection{Data Coverage}

Shoreline reference feature mapping has been performed in the following five sites: Ocean Shores, Westport, Cape Shoalwater, Fort Canby, WA and Clatsop, OR. Table 7 shows the extreme northern and southern extent of these surveys. Since shoreline reference feature positions change rapidly these bounding coordinates are not strictly adhered to during these surveys. Figures 15-19 present plan views of the shoreline reference features that have been mapped at each site.

Table 7. Shoreline Reference Feature Positions

\begin{tabular}{lcc}
\hline \multicolumn{1}{c}{ Site } & $\begin{array}{c}\text { Extreme Northern Extent } \\
\text { Northing }(\mathrm{m})\end{array}$ & $\begin{array}{c}\text { Extreme Southern Extent } \\
\text { Northing (m) }\end{array}$ \\
\hline Ocean Shores & 187622.36 & 183742.34 \\
Westport & 181426.49 & 177781.09 \\
\hline Cape Shoalwater & 163307.70 & 161116.17 \\
\hline Fort Canby & 113344.66 & 110353.21 \\
\hline Clatsop & 105108.52 & 102584.71 \\
\hline
\end{tabular}




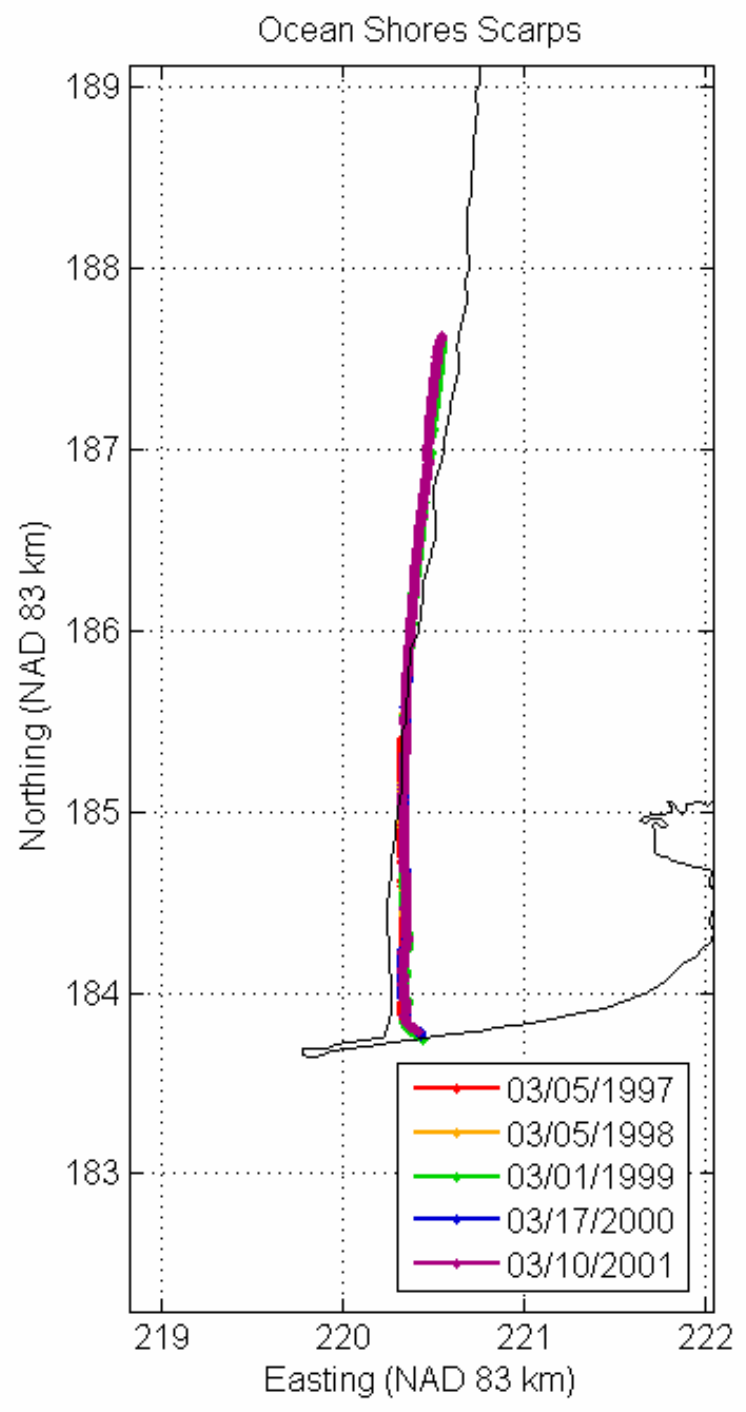

Figure 15. Shoreline reference features mapped at Ocean Shores, WA from 1997-2001. 


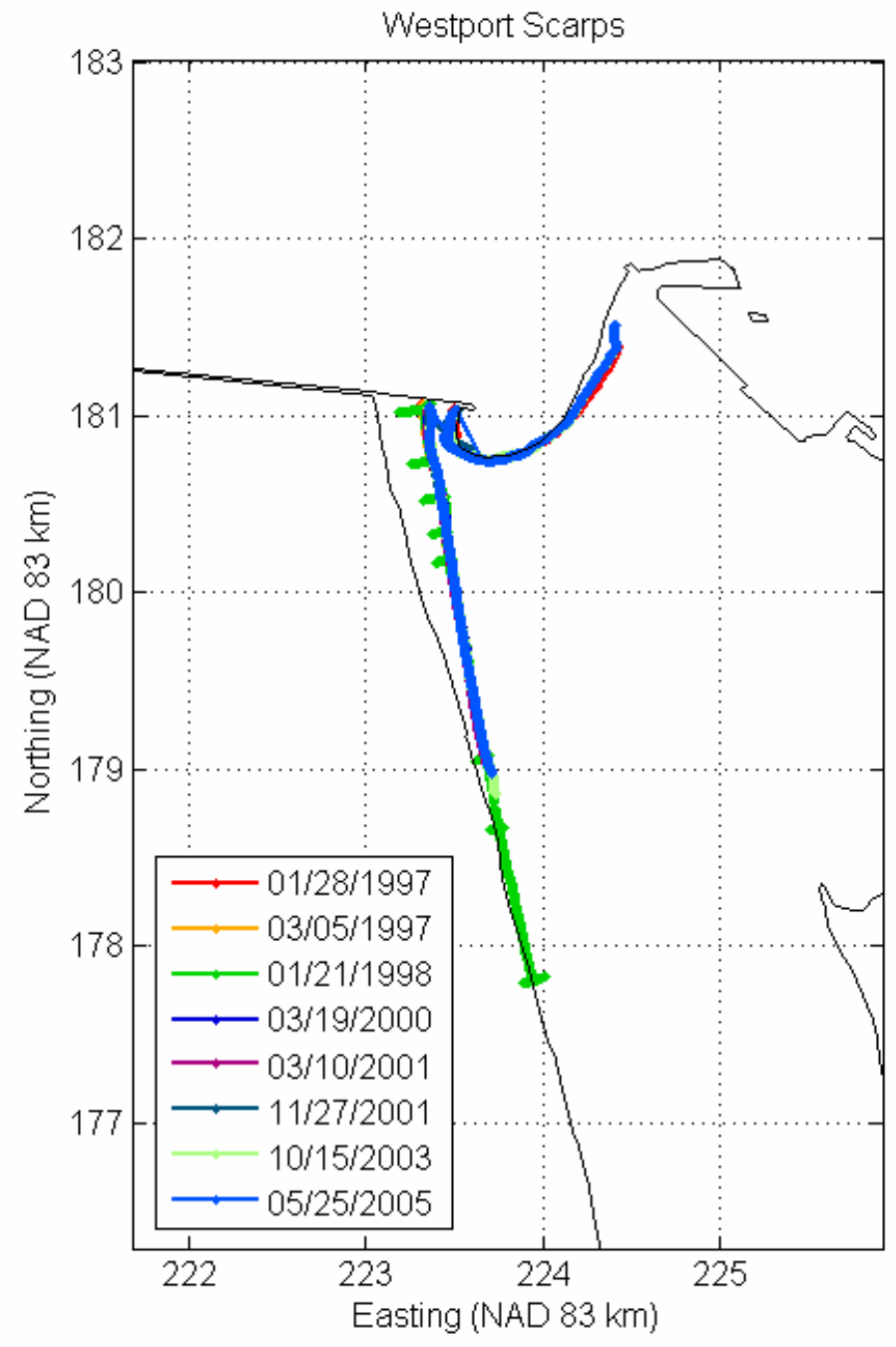

Figure 16. Shoreline reference features mapped at Westport, WA from 1997-2003. 


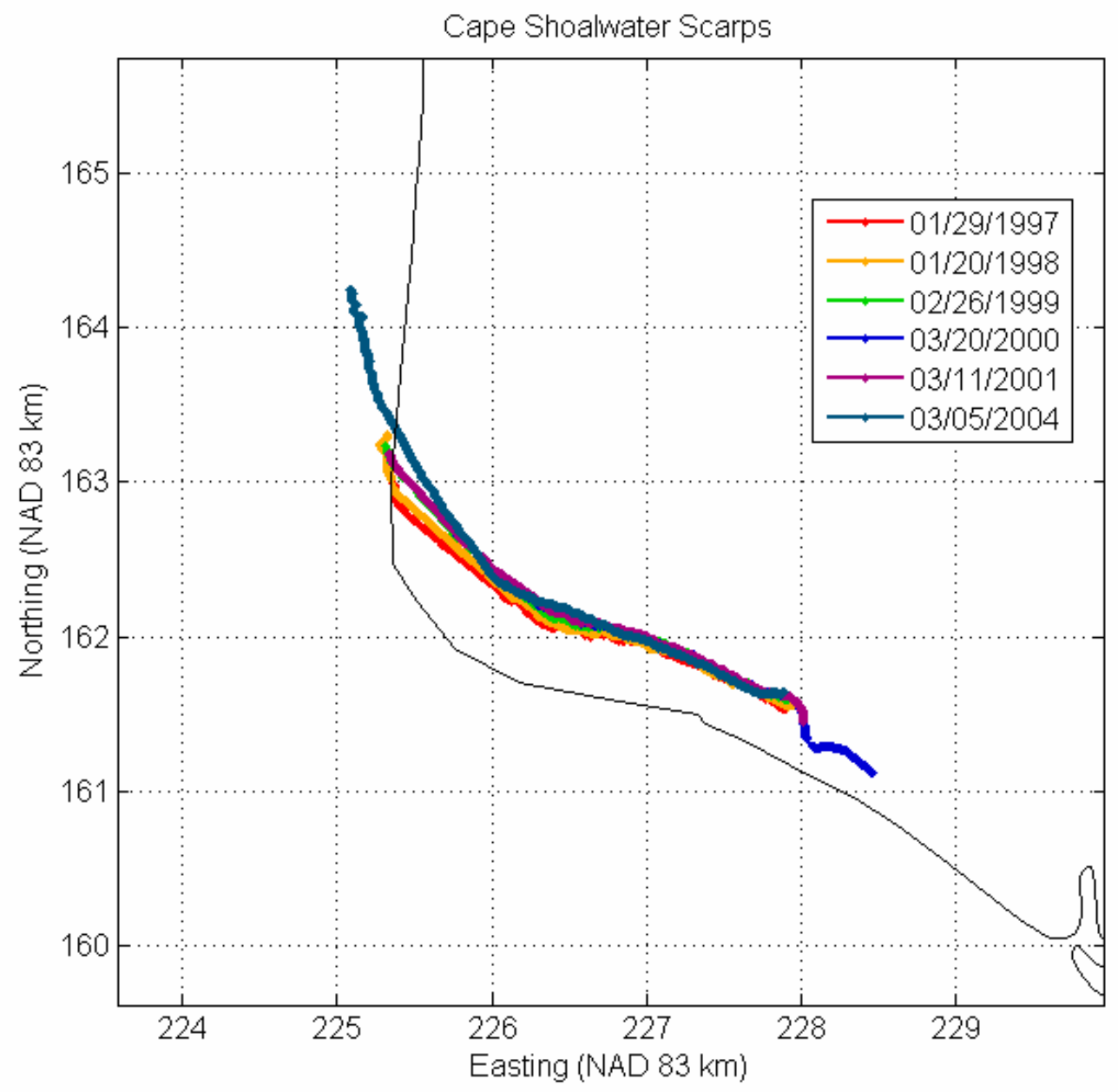

Figure 17. Shoreline reference features mapped at Cape Shoalwater, WA from 1997-2001. 


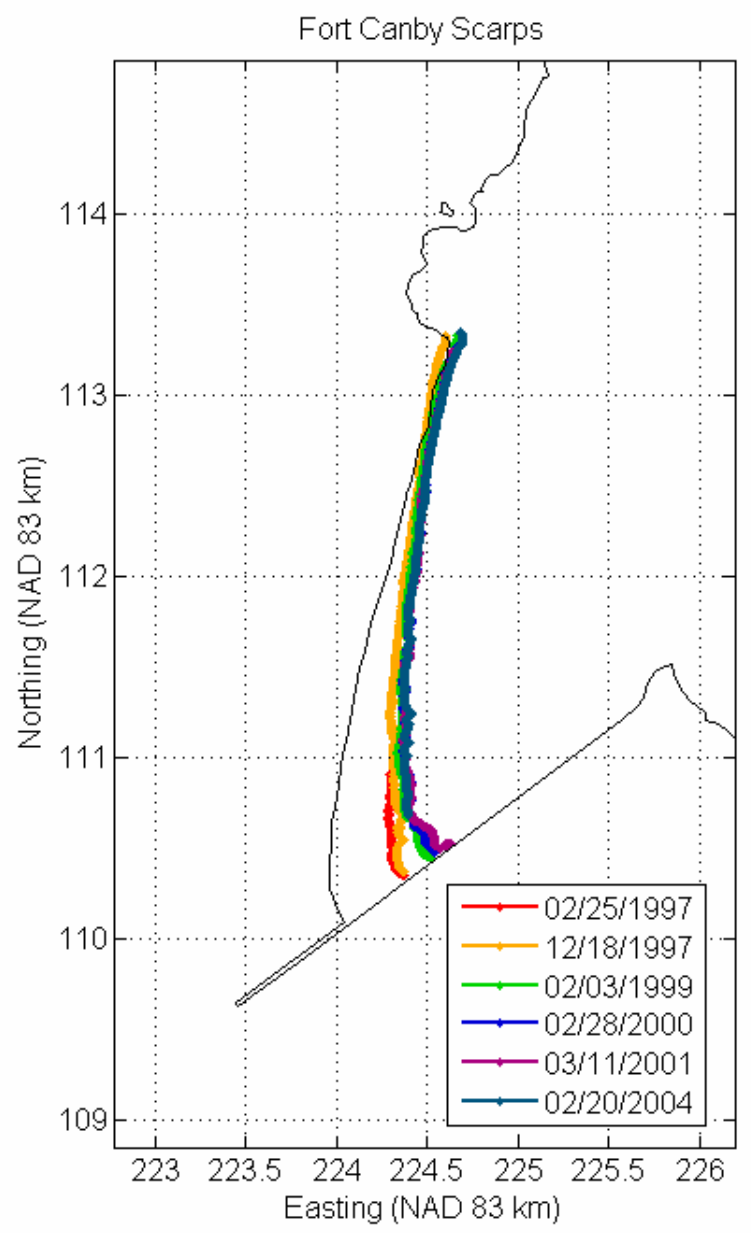

Figure 18. Shoreline reference features mapped at Ft Canby, WA from 1997-2004. 


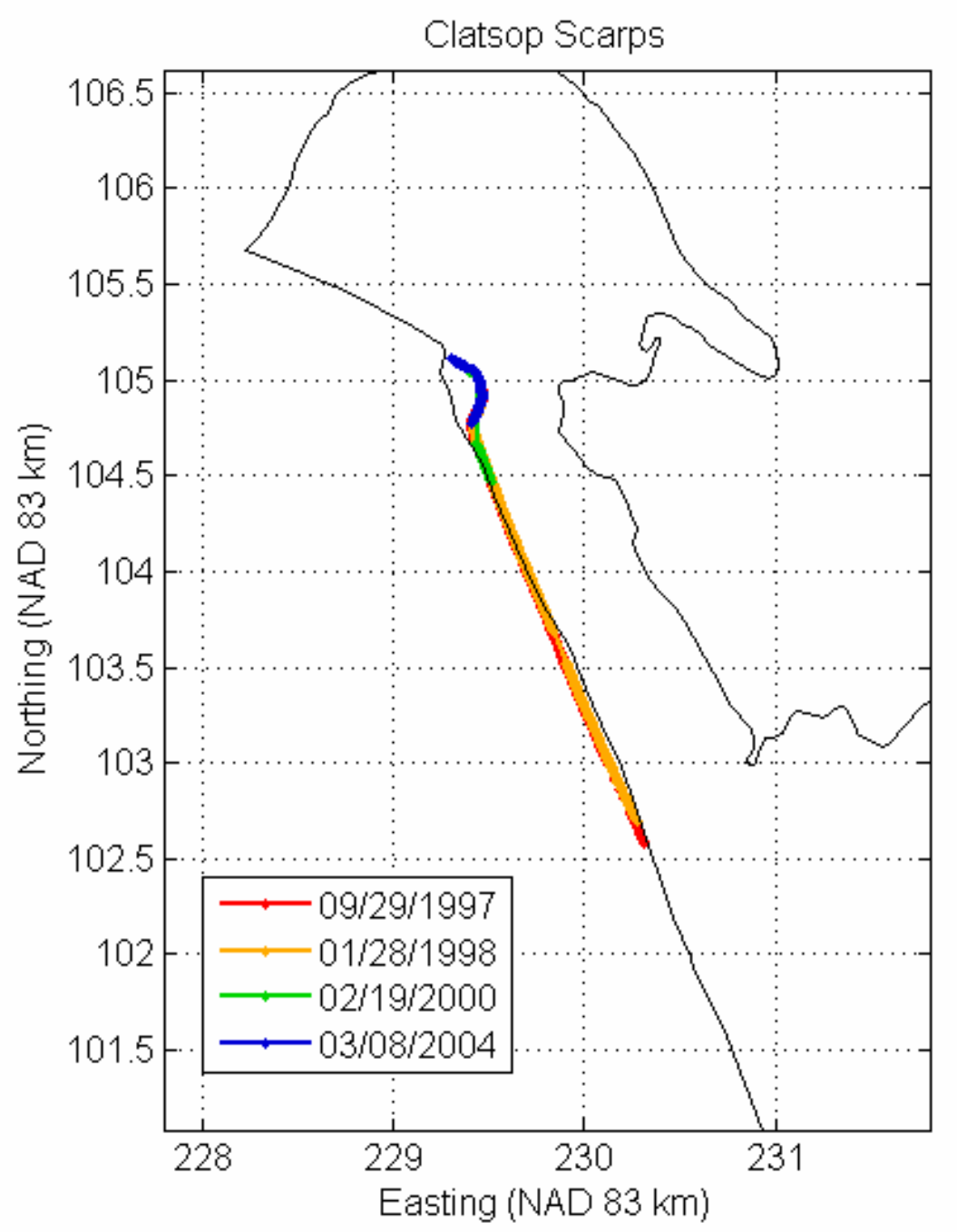

Figure 19. Shoreline reference features mapped at Clatsop, OR from 1997-2000.

\subsection{Nearshore Bathymetry}

We have collected over one thousand bathymetric profiles with the CPS since the field program began in 1998. Due to the impact of water temperature on echosounder data, the following sections discuss the environmental conditions during the surveys and the breadth of data coverage. 


\subsubsection{Environmental Conditions}

Tables 8- 15 indicate the broad range of environmental conditions in which the CPS made bathymetric surveys from 1998-2005. The environmental condition data is from the closest wave buoy to the survey site (Table 1). The GH and the CRB on the right hand side of each table stand for the CDIP 036 Grays Harbor Buoy and the NDBC 46029 Columbia River Buoy, respectively. The tables have data gaps where buoy data was unavailable for that time period. Wave heights ranged from $0.6 \mathrm{~m}$ to $2.8 \mathrm{~m}$, wave periods ranged from 4.5 seconds to 14.7 seconds, and wind speed ranged from $1.1 \mathrm{~m} / \mathrm{s}$ to $9.0 \mathrm{~m} / \mathrm{s}$. When wave heights were greater than $3 \mathrm{~m}$ conditions were determined to be too dangerous to collect data with the CPS. In Table 14, both buoys are referenced for Long Beach because measured water temperature values at the NDBC Columbia River buoy were unrealistically low, therefore water temperature measurements from the CDIP Grays Harbor buoy (those included in Table 14) were used for sound velocity corrections. All other environmental condition data for Long Beach listed in Table 14 is from the NDBC Columbia River buoy.

Table 8. List of bathymetric profiles collected by subcell and environmental conditions in 1998

\begin{tabular}{|c|c|c|c|c|c|c|c|c|c|c|}
\hline & & & Waves & & Wind & Temp & & & Buoy & \\
\hline Site / Date & Raw Data File & Profiles Collected & $\begin{array}{c}\text { Hs } \\
\mathrm{m}\end{array}$ & $\begin{array}{l}\text { Tp Dir } \\
\text { sec deg }\end{array}$ & $\begin{array}{l}\text { Speed Dir } \\
\text { m/sec deg }\end{array}$ & $\begin{array}{l}\text { Air } \\
{ }^{\circ} \mathrm{C}\end{array}$ & $\begin{array}{c}\text { Water } \\
{ }^{\circ} \mathrm{C}\end{array}$ & $\begin{array}{c}P \\
\mathrm{mb}\end{array}$ & GH & CRB \\
\hline
\end{tabular}

\begin{tabular}{|c|c|c|c|c|c|c|c|c|}
\hline $7 / 21 / 1998$ & nb_072198_b.xyz & $80,81,82,83,84$ & 1.36 & 7.50283 & 8.5 & 324 & 14.8 & $x$ \\
\hline $7 / 22 / 1998$ & nb_072298_b.xyz & $85,86,87,88,89$ & 1.50 & 8.40282 & 6.8 & 332 & 14.0 & $x$ \\
\hline 7/23/1998 & nb_072398_b.xyz & $90,91,92,93,94,95$ & 1.62 & 7.70294 & 4.8 & 316 & 13.3 & $x$ \\
\hline
\end{tabular}

\section{Grayland Plains}

\begin{tabular}{cccccccccc} 
7/15/1998 & gp_071598_b.xyz & $33,34,35,36,37,38$ & 1.71 & 7.60 & 236 & 4.5 & 164 & 15.0 & $x$ \\
\hline 7/16/1998 & gp_071698_b.xyz & $39,40,41,42$ & 1.20 & 7.40 & 243 & 2.4 & 242 & 15.2 & $x$
\end{tabular}

\section{Long Beach}

\begin{tabular}{|c|c|c|c|c|c|c|c|c|}
\hline $8 / 3 / 1998$ & lb_080398_b.xyz & $60,61,62,63,64,65,66$ & 0.96 & 5.20311 & 4.8 & 346 & 16.6 & $x$ \\
\hline 8/4/1998 & lb_080498_b.xyz & $67,68,69,70,71$ & 1.29 & 4.50346 & 9.2 & 340 & 16.7 & $x$ \\
\hline $8 / 5 / 1998$ & Ib_080598_b.xyz & $72,73,74,75,76$ & 0.90 & 6.20205 & 2.1 & 192 & 17.9 & $x$ \\
\hline 8/6/1998 & lb_080698_b.xyz & $220,219,218,217,216$ & 1.56 & 5.50264 & 6.3 & 336 & 16.0 & $x$ \\
\hline 8/7/1998 & lb_080798_b.xyz & $215,214,213$ & 1.54 & 5.40318 & 1.3 & 243 & 16.7 & $x$ \\
\hline
\end{tabular}




\begin{tabular}{ccccccccccc}
\hline 7/28/1998 & cp_072898_b.xyz & $83,84,85,86,87$ & 1.21 & 7.00310 & 1.1 & 244 & 17.5 & $x$ \\
\hline 7/30/1998 & cp_073098_b.xyz & 89,90 & 1.72 & 6.20304 & 5.7 & 298 & 16.5 & $x$ \\
\hline
\end{tabular}

Table 9. List of bathymetric profiles collected by subcell and environmental conditions in 1999

\begin{tabular}{|c|c|c|c|c|c|c|c|c|}
\hline & & Wave & & Wind & Temp & & & Buoy \\
\hline Site / Date & Profiles Collected & $\begin{array}{l}\mathrm{Hs} \\
\mathrm{m}\end{array}$ & $\begin{array}{l}\text { Tp } \\
\text { sec }\end{array}$ & $\begin{array}{l}\text { Dir Speed Dir } \\
\text { deg } \mathrm{m} / \mathrm{sec} \text { deg }\end{array}$ & $\begin{array}{l}\text { Air } \\
{ }^{\circ} \mathrm{C}\end{array}$ & $\begin{array}{c}\text { Water } \\
{ }^{\circ} \mathrm{C}\end{array}$ & $\begin{array}{c}P \\
\mathrm{mb}\end{array}$ & GH CRB \\
\hline
\end{tabular}

North Beach

\begin{tabular}{|c|c|c|c|c|c|}
\hline $7 / 15 / 1999$ & $1,1 \_b, 2,3,5,7,9,11,13,15,16 \_b$ & 1.46 & 9.72303 & 11.6 & $x$ \\
\hline $7 / 16 / 1999$ & $18 \_b, 20,22,24$ & 1.04 & 8.18299 & 11.2 & $x$ \\
\hline $7 / 20 / 1999$ & $\begin{array}{c}42,43,44,16,18,26,28 \\
30,32,34,36,38,40\end{array}$ & 1.25 & 7.53306 & 12.2 & $\mathrm{x}$ \\
\hline 7/21/1999 a.m. & $20,15,10,5,1,2,3,4,25,30,35$ & 0.75 & 6.55301 & 12.5 & $x$ \\
\hline 7/21/1999 p.m. & $40,45,50,55,60,65$ & 0.80 & 7.55302 & 13.5 & $x$ \\
\hline $7 / 22 / 1999$ & 15_b,19,18,17,16,14,13,12,11,12_Is & 0.90 & 8.35296 & 13.1 & $x$ \\
\hline
\end{tabular}

\section{Grayland Plains}

\begin{tabular}{|c|c|c|c|c|c|}
\hline 8/23/1999 & $32,33,34,35,36,37$ & 1.02 & $5.88 \quad 301$ & 14.7 & $x$ \\
\hline $8 / 24 / 1999$ & $\begin{array}{c}38,39,40,41,42,43,44,45 \\
46,47,48,49,50,51\end{array}$ & 0.75 & 8.13288 & 15.2 & $x$ \\
\hline 8/25/1999 & $52,53,54,55,56,57,58,59,60,61$ & 2.01 & 8.90273 & 15.0 & $x$ \\
\hline 8/26/1999 & $62,63,64,65,66,67,68,69,70,71,72,73$ & 1.27 & 8.48266 & 15.1 & $x$ \\
\hline 8/27/1999 & $31,30,29,28,27,26,25,24,23$ & 1.18 & 8.28275 & 13.6 & $x$ \\
\hline 8/30/1999 & $73 \_b, 74,75,76,77,78,79,80,81,82$ & 1.69 & $7.97 \quad 287$ & 12.6 & $x$ \\
\hline 8/31/1999 & $23 \_b, 22,21,20,19,18,17$ & 1.48 & $8.35 \quad 284$ & 14.4 & $x$ \\
\hline 9/1/1999 & $\begin{array}{c}99,98,97,96,95,94,93 \\
92,91,90,88,86,84\end{array}$ & 1.01 & 7.78277 & 13.5 & $x$ \\
\hline 9/2/1999 & 17,16 & 1.53 & 10.18284 & 12.9 & $x$ \\
\hline
\end{tabular}

\section{Long Beach}

\begin{tabular}{|c|c|c|c|c|c|c|c|c|c|c|}
\hline $7 / 27 / 1999$ & $\begin{array}{c}67,68,69,70,71,72,73,74,75,76 \\
77,77 \text { Is } 1,77 \text { Is } 266,65,64\end{array}$ & 1.06 & 7.70 & 303 & 5.59 & 335 & 12.8 & 14.8 & 1014.6 & $x$ \\
\hline $7 / 28 / 1999$ & $\begin{array}{c}199,190,200,198,197,196 \\
195,185,180,175,170,165\end{array}$ & 1.02 & 7.69 & 293 & 1.73 & 229 & 13.2 & 14.5 & 1017.9 & $x$ \\
\hline $7 / 29 / 1999$ & $\begin{array}{c}110,115,120,125,130,135,140 \\
145,150,155,160,105,100\end{array}$ & 1.11 & 8.48 & 300 & 2.98 & 307 & 14.1 & 15.1 & 1020.8 & $x$ \\
\hline 8/3/1999 & $221_{-} b, 220,219,218,217$ & 0.71 & 14.29 & 247 & 4.13 & 322 & 16.5 & 17.0 & 1021.0 & $x$ \\
\hline 8/5/1999 & $212,211,210,209,208,207,206,221$ & 0.95 & 9.70 & 277 & 5.30 & 333 & 15.3 & 15.9 & 1011.7 & $x$ \\
\hline 8/6/1999 & $95,90,85,80,64 \_b, 63$ & 1.08 & 6.25 & 316 & 2.03 & 233 & 14.7 & 15.4 & 1010.7 & $x$ \\
\hline
\end{tabular}

\section{Clatsop Plains}

$\begin{array}{lllllllllllll}8 / 10 / 1999 & 82,83,84,85,86,87,88,89,90,91,92 & 1.41 & 6.68 & 292 & 5.54 & 328 & 14.6 & 14.8 & 1011.6 & \times \\ 8 / 11 / 1999 & 93,94,95,96,97,98,99,100,101 & & 1.99 & 8.33 & 308 & 3.30 & 189 & 15.5 & 14.9 & 1016.5 & & x\end{array}$




\begin{tabular}{lccccccccccc}
\hline 8/12/1999 & $66,71,76,61,56 \_b$ & 1.16 & 10.74 & 295 & 2.20 & 290 & 14.8 & 14.7 & 1020.0 & $x$ \\
\hline $8 / 17 / 1999$ & $56,51,46,41,40,39,38,37,42,43 \_$Is & 0.93 & 8.81 & 261 & 5.30 & 300 & 15.3 & 16.5 & 1018.7 & $x$ \\
\hline $8 / 18 / 1999$ & $199,194,189,184,179,174,169,164,159$ & 1.00 & 12.50 & 265 & 3.00 & 217 & 15.9 & 16.9 & 1016.1 & $x$ \\
\hline $8 / 10 / 1999$ & $82,83,84,85,86,87,88,89,90,91,92$ & 1.41 & 6.68 & 292 & 5.54 & 328 & 14.6 & 14.8 & 1011.6 & $x$
\end{tabular}

Table 10. List of bathymetric profiles collected by subcell and environmental conditions in 2000

\begin{tabular}{|c|c|c|c|c|c|c|c|c|}
\hline \multirow[b]{2}{*}{ Site / Date } & \multirow[b]{2}{*}{ Profiles Collected } & \multicolumn{2}{|c|}{ Waves } & Wind & \multicolumn{2}{|c|}{ Temp } & \multicolumn{2}{|r|}{ Buoy } \\
\hline & & $\begin{array}{c}\text { Hs } \\
\text { m }\end{array}$ & $\begin{array}{l}\text { Tp } \\
\text { sec }\end{array}$ & $\begin{array}{l}\text { Dir Speed Dir } \\
\text { deg } \mathrm{m} / \mathrm{sec} \text { deg }\end{array}$ & $\begin{array}{l}\text { Air } \\
{ }^{\circ} \mathrm{C}\end{array}$ & $\begin{array}{c}\text { Water } \\
{ }^{\circ} \mathrm{C} \\
\end{array}$ & $\begin{array}{c}\mathbf{P} \\
\mathbf{m b}\end{array}$ & GH CRB \\
\hline \multicolumn{9}{|l|}{ North Beach } \\
\hline $7 / 19 / 2000$ & $79,80,81,82,83,84,85$ & 0.60 & 9.09 & 286 & & 14.1 & & $x$ \\
\hline $7 / 20 / 2000$ & $86,87,88,89,90$ & 0.92 & 8.00 & 287 & & 13.5 & & $x$ \\
\hline $7 / 25 / 2000$ & $\begin{array}{c}90 \_b, 90 \_I s 1,90 \_ \text {Is2,91, } \\
92,93,94,95,96,97,98\end{array}$ & 1.10 & 7.12 & 269 & & 13.3 & & $x$ \\
\hline $7 / 26 / 2000$ & $16,15,14,13,12,25$ & 1.05 & 7.47 & 280 & & 13.8 & & $x$ \\
\hline $8 / 7 / 2000$ & $60,65,69,74,55,50,45,40$ & 1.40 & 8.97 & 290 & & 16.0 & & $x$ \\
\hline $8 / 8 / 2000$ & 35,30,20,19,18,17,16_b & 1.74 & 8.12 & 298 & & 14.0 & & $x$ \\
\hline $8 / 9 / 2000$ & $11,10,9,8,7,6,5,4,3,2,1,20$ Is & 1.86 & 7.93 & 304 & & 13.7 & & $x$ \\
\hline
\end{tabular}

\section{Grayland Plains}

\begin{tabular}{|c|c|c|c|c|c|}
\hline $8 / 10 / 2000$ & 32 & 2.05 & 8.71305 & 13.6 & $x$ \\
\hline $8 / 11 / 2000$ & $\begin{array}{c}33,34,35,36,37,38,39,40,41 \\
42,43,44,45,46,47,48,53\end{array}$ & 1.21 & 7.58298 & 15.1 & $x$ \\
\hline $8 / 12 / 2000$ & $\begin{array}{c}99,98,97,96,95,94,93,92,91,90 \\
89,88,87,86,83,78,73,68,63\end{array}$ & 0.83 & 7.89293 & 14.5 & $x$ \\
\hline
\end{tabular}

\begin{tabular}{|c|c|c|c|c|c|c|c|c|c|}
\hline $8 / 24 / 2000$ & 60,61,62,63,64,65,66,67_b & 1.25 & 13.54261 & 4.1 & 164 & 16.1 & 16.1 & 1021.0 & $x$ \\
\hline $8 / 28 / 2000$ & $67,68,69,70,71,72,73,74$ & 1.75 & 7.87309 & 8.5 & 336 & 15.0 & 15.1 & 1018.2 & $x$ \\
\hline $9 / 5 / 2000$ & $\begin{array}{c}211,212,213,214,215,216, \\
217,204 \text { _Is,218,219,220, } \\
221,210,209,208,207,206\end{array}$ & 1.03 & 14.67217 & 1.8 & 202 & 14.6 & 15.2 & 1025.1 & $x$ \\
\hline $9 / 6 / 2000$ & $\begin{array}{c}200,199,198,197,196,195 \\
190,185,180,175,170,165 \\
160,155,150,145,140\end{array}$ & 1.60 & 9.61305 & 3.6 & 297 & 15.4 & 16.7 & 1025.3 & $x$ \\
\hline $9 / 7 / 2000$ & $\begin{array}{c}110,105,100,95,90,85,80,77 \\
76,75,115,135,130,125,120\end{array}$ & 1.23 & 12.25282 & 5.6 & 178 & 14.8 & 15.7 & 1014.8 & $\mathrm{x}$ \\
\hline
\end{tabular}

\section{Clatsop Plains}

\begin{tabular}{|c|c|c|c|c|c|c|c|c|c|c|}
\hline 9/19/2000 & $66,61,56,51,46,42 \_b$ & 1.94 & 10.37 & 287 & 7.8 & 350 & 14.3 & 15.6 & 1021.6 & $x$ \\
\hline $9 / 21 / 2000$ & $\begin{array}{l}42,41,40,39,38,37,71 \\
76,82,83,84,85,86,87\end{array}$ & 2.57 & 9.74 & 297 & 7.5 & 292 & 14.4 & 15.5 & 1008.1 & $x$ \\
\hline $9 / 22 / 2000$ & $\begin{array}{l}88,89,90,91,92,93,94,95,96,97 \\
98,99,100,101,199,194,189,184\end{array}$ & 1.54 & 8.89 & 310 & 4.8 & 49 & 14.1 & 15.0 & 1014.9 & $x$ \\
\hline
\end{tabular}


Table 11. List of bathymetric profiles collected by subcell and environmental conditions in 2001

\begin{tabular}{|c|c|c|c|c|c|c|c|c|}
\hline \multirow[b]{2}{*}{ Site / Date } & \multirow[b]{2}{*}{ Profiles Collected } & \multicolumn{2}{|c|}{ Waves } & Wind & \multicolumn{2}{|c|}{ Temp } & \multicolumn{2}{|r|}{ Buoy } \\
\hline & & $\begin{array}{l}\text { Hs } \\
\text { m }\end{array}$ & $\begin{array}{l}\text { Tp } \\
\text { sec }\end{array}$ & $\begin{array}{l}\text { Dir Speed Dir } \\
\text { deg } \mathrm{m} / \mathrm{sec} \text { deg }\end{array}$ & $\begin{array}{l}\text { Air } \\
{ }^{\circ} \mathrm{C}\end{array}$ & $\begin{array}{c}\text { Water } \\
{ }^{\circ} \mathrm{C} \\
\end{array}$ & $\begin{array}{c}\mathbf{P} \\
\mathrm{mb}\end{array}$ & GH CRB \\
\hline \multicolumn{9}{|l|}{ North Beach } \\
\hline $8 / 6 / 2001$ & $20,20 \_b, 19,17,16,15,13$ & 1.74 & 10.04 & 274 & & 15.8 & & $x$ \\
\hline $8 / 8 / 2001$ & $18,14,12,11,10$ & 1.57 & 8.35 & 289 & & 15.1 & & $x$ \\
\hline $8 / 9 / 2001$ & $\begin{array}{c}79,79 \text { b, } 80,81,82,83,84,85 \\
86,87,88,89,90,91,92,93 \\
94,95,96,97,98,99,74,65\end{array}$ & 1.28 & 8.13 & 301 & & 14.6 & & $\mathrm{x}$ \\
\hline 8/10/2001 & $\begin{array}{l}\text { 9,9_b,8,7,6,5,4,3,2,1, } \\
25,30,35,40,45,50,55\end{array}$ & 1.14 & 7.51 & 297 & & 15.2 & & $x$ \\
\hline
\end{tabular}

\section{Grayland Plains}

\begin{tabular}{|c|c|c|c|c|c|}
\hline 7/17/2001 & $\begin{array}{l}32,32 \_b, 33,34,35,36,37,38,39,40 \\
41,42,43,44,45,46,47,48,53,58,63\end{array}$ & 1.18 & 7.09296 & 11.8 & $x$ \\
\hline 7/18/2001 & $\begin{array}{c}99,98,97,96,95,94,93,92,91,90,89,88 \\
87,86,83,78 \_b, 73,68,78,84,85\end{array}$ & 0.78 & 7.28278 & 12.7 & $x$ \\
\hline 7/19/2001 & $\begin{array}{l}\text { 32_c,32_d,gl_Is1,gl_Is2, } \\
\text { gl_Is3,30,25,20,18,16,15 }\end{array}$ & 1.11 & 8.17292 & 13.2 & $x$ \\
\hline
\end{tabular}

\section{Long Beach}

\begin{tabular}{|c|c|c|c|c|c|c|c|c|c|}
\hline $7 / 23 / 2001$ & $\begin{array}{c}60,60 \_b, 61,62,63,64,65,66,67,68,69 \\
70,71,72,73,74,75,76,77,80\end{array}$ & 0.97 & 14.29221 & 4.6 & 324 & 14.1 & 14.1 & 1019.9 & $x$ \\
\hline 7/24/2001 & $\begin{array}{c}211,212,212 \text { b,213,214,215,216, } \\
\text { 217,218,219,220,221,210,209, } \\
208,207,206, \text { ftcan_Is1,ftcan_Is } 2\end{array}$ & 2.33 & 9.09315 & 6.1 & 325 & 14.6 & 14.7 & 1020.4 & $x$ \\
\hline $7 / 25 / 2001$ & $\begin{array}{l}200,200 \_b, 199,198,197,196,195 \\
190185,180,175,170,165,160,155\end{array}$ & 1.96 & 8.22316 & 7.0 & 322 & 14.0 & 13.6 & 1019.9 & $x$ \\
\hline $7 / 26 / 2001$ & $\begin{array}{c}150,145,140,135,130,125,120,115, \\
110105,100,95,90,85,85 \_b, 85 \_c\end{array}$ & 1.29 & 7.87315 & 6.0 & 327 & 13.8 & 13.8 & 1020.5 & $x$ \\
\hline
\end{tabular}

\section{Clatsop Plains}

\begin{tabular}{|c|c|c|c|c|c|c|c|c|c|c|}
\hline $7 / 30 / 2001$ & $\begin{array}{l}101,100,100 \_b, 99,98,97 \\
96,95,94,93,92,91,90,89\end{array}$ & 1.74 & 10.00 & 288 & 4.8 & 316 & 13.8 & 13.3 & 1018.7 & $x$ \\
\hline $7 / 31 / 2001$ & $\begin{array}{l}88,88 \_b, 87,86,85,84,83,82,76,71 \\
66,61,56,51,46,42,41,40,39,38,37\end{array}$ & 1.40 & 8.73 & 293 & 0.5 & 226 & 15.1 & 13.9 & 1019.9 & $\mathrm{x}$ \\
\hline 8/1/2001 & $\begin{array}{c}106,111,116,121,126 \\
131,136,141,146\end{array}$ & 0.93 & 7.25 & 279 & 5.3 & 168 & 14.4 & 13.4 & 1017.8 & $x$ \\
\hline
\end{tabular}

Table 12. List of bathymetric profiles collected by subcell and environmental conditions in 2002

\begin{tabular}{|c|c|c|c|c|c|c|c|c|}
\hline \multirow[b]{2}{*}{ Site / Date } & \multirow[b]{2}{*}{ Profiles Collected } & \multicolumn{2}{|c|}{ Waves } & Wind & \multicolumn{2}{|c|}{ Temp } & \multicolumn{2}{|r|}{ Buoy } \\
\hline & & $\begin{array}{c}\mathrm{Hs} \\
\mathrm{m}\end{array}$ & $\begin{array}{l}\text { Tp } \\
\text { sec }\end{array}$ & $\begin{array}{l}\text { Dir Speed Dir } \\
\text { deg } \mathrm{m} / \mathrm{sec} \text { deg }\end{array}$ & $\begin{array}{l}\text { Air } \\
{ }^{\circ} \mathrm{C} \\
\end{array}$ & $\begin{array}{c}\text { Water } \\
{ }^{\circ} \mathrm{C} \\
\end{array}$ & $\begin{array}{c}P \\
\mathbf{m b}\end{array}$ & GH CRB \\
\hline \multicolumn{9}{|l|}{ North Beach } \\
\hline $8 / 10 / 2002$ & $20,19,18,16,15,14,13,12,11,10,9,8,7$ & 1.4 & 7.53 & 289 & & 12.2 & & $x$ \\
\hline $8 / 12 / 2002$ & $17,6,5,4,3,2,1,25,30,35,40,45,50$ & 1.4 & 8.24 & 306 & & 12.1 & & $x$ \\
\hline
\end{tabular}




\begin{tabular}{ccccccc}
\hline $8,13 / 2002$ & $\begin{array}{c}79,80,81,82,83,84,85,86,87, \\
88,89,9091,92,93,94,95\end{array}$ & 1.0 & 7.97 & 300 & 12.5 & $X$ \\
$8 / 14 / 2002$ & $96,97,98,99,99,74,69$, & 2.8 & 9.74 & 297 & 12.6 & $\times$ \\
\hline
\end{tabular}

\section{Grayland Plains}

\begin{tabular}{|c|c|c|c|c|c|}
\hline $7 / 24 / 2002$ & $\begin{array}{c}32,33,34,35,36,37,38,39,40 \\
41,42,43,44,45,46,47,48\end{array}$ & 1.1 & 7.97284 & 13.0 & $x$ \\
\hline $7 / 25 / 2002$ & $99,97,98,95,96,93,94,92$ & 1.3 & 7.32288 & 14.0 & $x$ \\
\hline 8/9/2002 & $91,90,89,88,63,58,53,68,73,78,83,87$ & 1.1 & 8.65279 & 14.8 & $x$ \\
\hline
\end{tabular}

\section{Long Beach}

\begin{tabular}{|c|c|c|c|c|c|c|c|c|c|c|}
\hline $7 / 15 / 2002$ & $\begin{array}{c}211 \_b, 211,212,213,214,215, \\
216,217,218,219,220,221,223\end{array}$ & 0.9 & 5.74 & 306 & 6.1 & 331 & 14.4 & 14.1 & 1016.6 & $x$ \\
\hline $7 / 16 / 2002$ & $\begin{array}{l}210,209,208,208,207,206, b b 30 \\
\text { bb32,bb34,222,bb36,bb38 }\end{array}$ & 1.3 & 8.33 & 281 & 1.9 & 247 & 16.2 & 16.6 & 1015.5 & $x$ \\
\hline $7 / 17 / 2002$ & $\begin{array}{c}200,200,199,198,197 \\
196,195,190,185,180 \\
175,170,165,160,155,150\end{array}$ & 1.5 & 8.20 & 278 & 4.2 & 200 & 15.5 & 15.4 & 1017.2 & $x$ \\
\hline $7 / 18 / 2002$ & $\begin{array}{c}115,120,125,135,140 \\
145,130,110,105,100,95\end{array}$ & 1.4 & 9.09 & 281 & 2.0 & 197 & 15.9 & 15.9 & 1018.0 & $\mathrm{X}$ \\
\hline $7 / 19 / 2002$ & $66,65,64,63,62,61,60,67,68,69,70$ & 1.2 & 8.71 & 274 & 4.7 & 337 & 17.0 & 16.7 & 1020.5 & $x$ \\
\hline $7 / 22 / 2002$ & $\begin{array}{l}72,71,73,74,75,76 \\
77,80,85,90,95,73\end{array}$ & 2.2 & 8.94 & 309 & 1.9 & 267 & 15.8 & 14.6 & 1011.6 & $x$ \\
\hline
\end{tabular}

\section{Clatsop Plains}

\begin{tabular}{cccccccccccc}
$8 / 19 / 2002$ & $38,39,40,41,42,46,51,56,61,66,71,76$ & 1.6 & 7.27 & 317 & 3.9 & 349 & 13.7 & 14.2 & 1015.9 & $X$ \\
\hline $8 / 20 / 2002$ & $\begin{array}{c}81,82,83,84,85,86,87,88,89,90,91,92, \\
93,94,95,96,97,98,99,100,101\end{array}$ & 0.7 & 14.89 & 226 & 3.4 & 262 & 14.6 & 15.6 & 1018.3 & $X$ \\
\hline
\end{tabular}

Table 13. List of bathymetric profiles collected by subcell and environmental conditions in 2003

\begin{tabular}{|c|c|c|c|c|c|c|c|c|c|c|c|}
\hline \multirow[b]{2}{*}{ Site / Date } & \multirow[b]{2}{*}{ Profiles Collected } & \multicolumn{3}{|c|}{ Waves } & \multirow{2}{*}{$\begin{array}{c}\text { Wind } \\
\text { Speed }\end{array}$} & \multicolumn{3}{|c|}{ Temp } & \multicolumn{3}{|c|}{ Buoy } \\
\hline & & $\begin{array}{l}\mathrm{Hs} \\
\mathrm{m}\end{array}$ & $\begin{array}{c}\text { Tp } \\
\text { sec }\end{array}$ & $\begin{array}{l}\text { Dir } \\
\text { deg }\end{array}$ & & $\begin{array}{c}\text { Dir } \\
\text { deg }\end{array}$ & $\begin{array}{l}\text { Air } \\
{ }^{\circ} \mathrm{C}\end{array}$ & $\begin{array}{c}\text { Water } \\
{ }^{\circ} \mathrm{C}\end{array}$ & $\begin{array}{c}P \\
m b\end{array}$ & GH & CRB \\
\hline
\end{tabular}

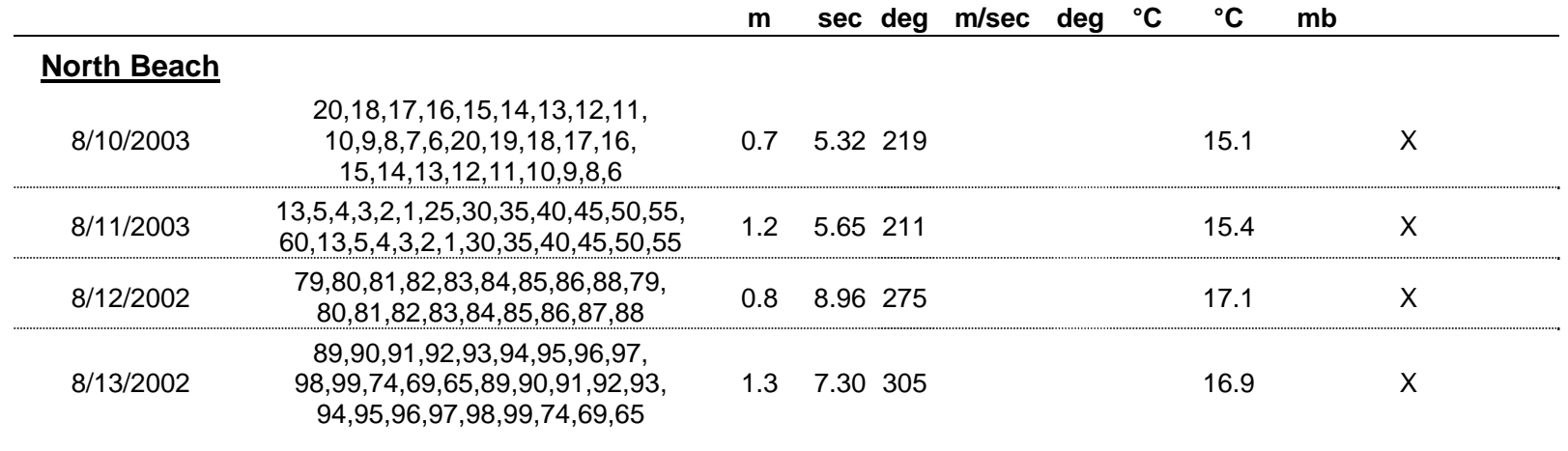

\section{Grayland Plains}

30,31,32,33,34,35,36,37,38,39,

$\begin{array}{llllll}40,41,42,43,44,45,46,30,31,32, & 0.9 & 7.20 & 301 & 13.1 & X\end{array}$




\begin{tabular}{|c|c|c|c|c|c|c|c|c|c|}
\hline $8 / 6 / 2003$ & $\begin{array}{c}99,98,96,95,94,93,92,91,90,89,88,87 \\
86,85,84,83,78,73,99,97,95,94,92,91 \\
90,89,88,87,86,85,84,83,78,73\end{array}$ & 1.0 & 7.04303 & & & 12.0 & & $x$ & \\
\hline 8/7/2003 & $\begin{array}{c}46,47,48,53,58,63,68,25,20,15 \\
46,47,48,53,58,63,68,25,20,15\end{array}$ & 0.7 & 9.95260 & & & 12.1 & & $x$ & \\
\hline \multicolumn{10}{|c|}{ Long Beach } \\
\hline $7 / 28 / 2003$ & $199,200,199,198,197,196,195$ & 1.7 & 8.17320 & 5.6 & 31815.43 & 14.9 & 1017.7 & & $x$ \\
\hline $7 / 29 / 2003$ & $\begin{array}{c}190,185,175,165,155,145,130,190 \\
180,170,160,150,140,135,125\end{array}$ & 1.5 & 8.33322 & 3.6 & 32015.82 & 15.9 & 1016.8 & & $x$ \\
\hline $7 / 30 / 2003$ & $\begin{array}{c}66,65,63,60,50,68,70,72,73,66 \\
64,62,61,55,45,67,69,71\end{array}$ & 2.1 & 9.09316 & 7.6 & 33415.78 & 15.9 & 1017.0 & & $x$ \\
\hline $7 / 31 / 2003$ & $\begin{array}{c}125,135,105,95,90,85,76,115,120 \\
130,135,110,100,95,80,77,75,74\end{array}$ & 1.8 & 8.79322 & 5.0 & 34814.90 & 14.8 & 1019.6 & & $x$ \\
\hline 8/1/2003 & $\begin{array}{c}211,212,214,215,217,219,220,221 \\
222,210,209,208,207,206,203 \\
211,213,216,218,220,221,222 \\
223,224,210,209,208,207\end{array}$ & 0.9 & 10.00285 & 5.3 & 28915.02 & 15.1 & 1019.8 & & $x$ \\
\hline
\end{tabular}

\begin{tabular}{|c|c|c|c|c|c|c|c|c|c|}
\hline $9 / 15 / 2003$ & $5,5,6,7,8,9$ & 2.1 & 9.55 & 309 & 2.4 & 22415.00 & 15.0 & 1015.9 & $x$ \\
\hline $9 / 16 / 2003$ & $\begin{array}{c}10,11,16,19,24,25,26,29,10 \\
11,12,13,14,15,17,18,20 \\
20 \text { cross }, 21,22,22 \text { _cross }, 23,27,28,30\end{array}$ & 1.6 & 8.30 & 298 & 6.3 & 29514.35 & 14.5 & 1015.0 & $x$ \\
\hline 9/17/2003 & $\begin{array}{c}31,33,36,56,61,31,32,34,37,38 \\
39,40,41,42,46,51,56,66,71\end{array}$ & 1.4 & 7.71 & 307 & 3.8 & 19614.43 & 14.4 & 1022.8 & $x$ \\
\hline 9/18/2003 & $\begin{array}{c}66,76,85,87,89,91,93,66,82,83 \\
84,86,88,90,92,94,96,97\end{array}$ & 1.9 & 7.90 & 282 & 9.0 & 18214.20 & 13.7 & 1016.8 & $x$ \\
\hline
\end{tabular}

Table 14. List of bathymetric profiles collected by subcell and environmental conditions in 2004

\begin{tabular}{|c|c|c|c|c|c|c|c|c|c|c|}
\hline \multirow[b]{2}{*}{ Site / Date } & \multirow[b]{2}{*}{ Profiles Collected } & \multicolumn{2}{|c|}{ Waves } & \multirow{2}{*}{$\begin{array}{l}\text { Wind } \\
\text { Speed } \\
\mathrm{m} / \mathrm{sec}\end{array}$} & \multicolumn{3}{|c|}{ Temp } & \multicolumn{3}{|c|}{ Buoy } \\
\hline & & $\begin{array}{c}\text { Hs } \\
\text { m }\end{array}$ & $\begin{array}{l}\text { Tp Dir } \\
\text { sec deg }\end{array}$ & & $\begin{array}{l}\text { Dir } \\
\text { deg }\end{array}$ & $\begin{array}{l}\text { Air } \\
{ }^{\circ} \mathrm{C}\end{array}$ & $\begin{array}{c}\text { Water } \\
{ }^{\circ} \mathrm{C}\end{array}$ & $\begin{array}{c}P \\
m b\end{array}$ & GH & CRB \\
\hline \multicolumn{11}{|l|}{ North Beach } \\
\hline $8 / 17 / 2004$ & $25,20,19,18,16,14,12,10,8,17,15,13,11$ & 0.6 & 8.19244 & & & & 17.7 & & $\mathrm{x}$ & \\
\hline $8 / 18 / 2004$ & $35,9,6,4,2,40,50,30,7,5,3,1,45,55,65,60$ & 1.2 & 12.7270 & & & & 15.4 & & $x$ & \\
\hline $8 / 19 / 2004$ & $\begin{array}{c}98,96,94,92,90,88,86,84,82,80,99,97,95 \\
93,91,89,87,85,83,81,79,69\end{array}$ & 1.3 & 6.41303 & & & & 15.5 & & $x$ & \\
\hline
\end{tabular}

\section{Grayland Plains}

\begin{tabular}{|c|c|c|c|c|c|}
\hline $8 / 15 / 2004$ & $\begin{array}{c}99,97,95,93,91,89,87,85,83,73,63,109 \\
107,105,103,101,98,96,94,92,90,88,86 \\
84,78,67,68,108,106,104,102,100\end{array}$ & 0.7 & 7.77274 & 16.4 & $x$ \\
\hline 8/16/2004 & $\begin{array}{c}53,48,47,46,45,44,43,42,41,40,39,38,37 \\
36,35,34,33,32,31,25,20,15\end{array}$ & 0.6 & 8.19244 & 17.7 & $x$ \\
\hline
\end{tabular}

\section{Long Beach}

\begin{tabular}{|c|c|c|c|c|c|c|c|c|c|c|}
\hline $7 / 28 / 2004$ & $\begin{array}{c}210,211,213,215,217,219,31,33,35,37 \\
39,266,204,202,212,214,216,218,30,32 \\
34,36,38,268,264\end{array}$ & 2.1 & 8.84313 & 3.7 & 323 & 15.68 & 16.1 & 1017.2 & $x$ & $x$ \\
\hline $7 / 29 / 2004$ & $206,207,209,203,205,208$ & 2.2 & 8.33310 & 5.3 & 334 & 15.42 & 16.3 & 1017.2 & $x$ & $x$ \\
\hline
\end{tabular}




\begin{tabular}{|c|c|c|c|c|c|c|c|c|c|c|}
\hline $7 / 30 / 2004$ & $\begin{array}{c}201,200,198,195,185,175,165,155,145 \\
199,198,197,196,190,180,170,160,150 \\
140\end{array}$ & 1.4 & 7.28302 & 1.6 & 266 & 16.00 & 15.3 & 1016.6 & $\mathrm{x}$ & $x$ \\
\hline $7 / 31 / 2004$ & $115,120,125,130,135,115,110,105$ & 2.0 & 8.12305 & 4.4 & 308 & 14.77 & 17.5 & 1014.3 & $x$ & $x$ \\
\hline $8 / 1 / 2004$ & $100,95,90,85,80,77,76,75,74,73,72,71$ & 2.1 & 8.71309 & 3.4 & 315 & 14.80 & 16.9 & 1014.1 & $x$ & $x$ \\
\hline $8 / 2 / 2004$ & $69,70,68,66,65,64,63,62,61,60$ & 1.2 & 7.42315 & 1.4 & 171 & 14.90 & 15.3 & 1015.8 & $x$ & $x$ \\
\hline
\end{tabular}

\section{Clatsop Plains}

$8 / 20 / 2004 \quad 66,56,42,40,71,61,51,46,41,39,38,37$, 40,76

Table 15. List of bathymetric profiles collected by subcell and environmental conditions in 2005

\begin{tabular}{|c|c|c|c|c|c|c|c|c|c|c|}
\hline & & Waves & & Wind & & Temp & & & Buoy & \\
\hline Site / Date & Profiles Collected & $\begin{array}{l}\text { Hs } \\
\text { m }\end{array}$ & $\begin{array}{l}\text { Tp Dir } \\
\text { sec deg }\end{array}$ & $\begin{array}{l}\text { Speed } \\
\mathrm{m} / \mathrm{sec}\end{array}$ & $\begin{array}{l}\text { Dir } \\
\text { deg }\end{array}$ & $\begin{array}{l}\text { Air } \\
{ }^{\circ} \mathrm{C}\end{array}$ & $\begin{array}{c}\text { Water } \\
{ }^{\circ} \mathrm{C}\end{array}$ & $\begin{array}{c}\mathbf{P} \\
\mathbf{m b}\end{array}$ & GH & CRB \\
\hline \multicolumn{11}{|l|}{ North Beach } \\
\hline $9 / 17 / 2005$ & $\begin{array}{c}25,19,17,15,13,11,9,4,25,20,18,16,14 \\
12,10,8,7,6,5,3,2,1,30,35\end{array}$ & 1.0 & 18.18230 & & & & 13.7 & & $x$ & \\
\hline $9 / 18 / 2005$ & $\begin{array}{c}81,82,85,86,89,90,93,94,97,98,74,45 \\
79,80,83,84,87,88,91,92,95,96,99,69 \\
65,60,55,50,40\end{array}$ & 0.8 & 16.67229 & & & & 14.5 & & $x$ & \\
\hline
\end{tabular}

\section{Grayland Plains}

\begin{tabular}{|c|c|c|c|c|c|}
\hline $8 / 20 / 2005$ & $\begin{array}{c}35,37,39,41,43,45,47,58,68,30,32,31 \\
33,34,36,38,40,42,44,46,48,53,63\end{array}$ & 0.6 & 14.29223 & 11.2 & $x$ \\
\hline $8 / 21 / 2005$ & $\begin{array}{c}98,96,94,92,90,88,86,84,78,97,99,97 \\
95,93,91,92,89,87,85,83,73,99\end{array}$ & 1.1 & 7.20304 & 12.7 & $x$ \\
\hline
\end{tabular}

\section{Long Beach}

\begin{tabular}{|c|c|c|c|c|c|c|c|c|c|c|}
\hline $8 / 23 / 2005$ & $\begin{array}{c}214,215,216,217,218,219,30,220,32,221, \\
34,222,36,223,38,224,213,212,211,210, \\
209,208,207,206\end{array}$ & 1.6 & 7.32 & 317 & 2.0 & 295 & 15.55 & 13.5 & 1017.5 & $x$ \\
\hline $8 / 24 / 2005$ & $\begin{array}{c}200,201,199,198,202,203,204,205,197 \\
196,195,190,185,180,175,170,165,160 \\
155,150\end{array}$ & 1.3 & 7.42 & 314 & 8.2 & 333 & 14.42 & 12.9 & 1013.5 & $x$ \\
\hline 9/21/2005 & $\begin{array}{c}61,63,65,67,69,71,73,75,85,95,105,115 \\
60,62,64,66,68,70,72,74,76,77,80,90 \\
100,110\end{array}$ & 1.9 & 11.1 & 297 & 7.9 & 334 & 13.47 & 12.1 & 1022.7 & $x$ \\
\hline
\end{tabular}

\section{Clatsop Plains}

9/22/2005 


\subsubsection{Data Coverage}

Figures 20-21 show the locations, in plan view, of each of the bathymetric profiles collected between 1998 and 2005 .

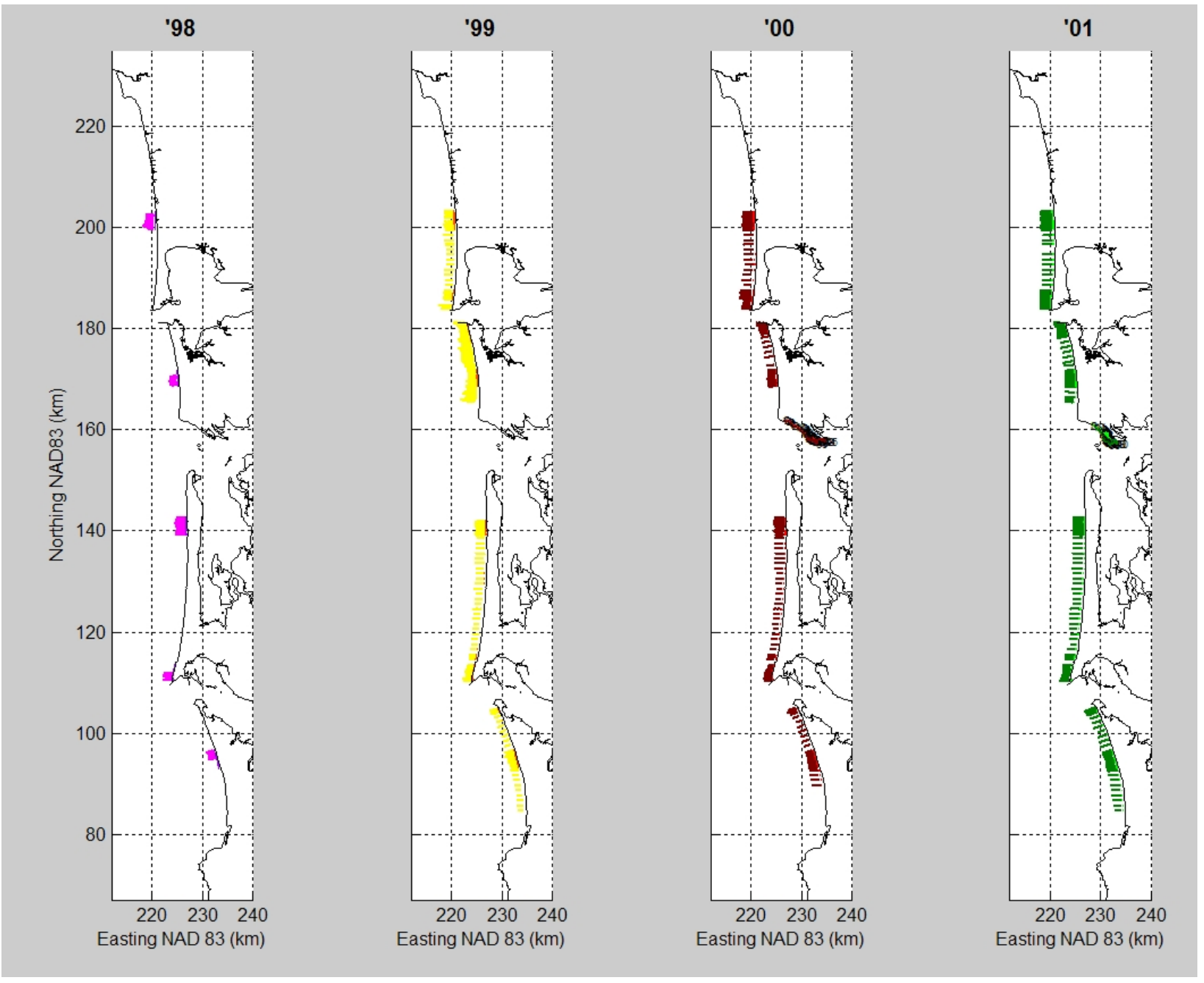

Figure 20. Nearshore bathymetry profiles collected from 1998-2001 in each of the four sub cells. 

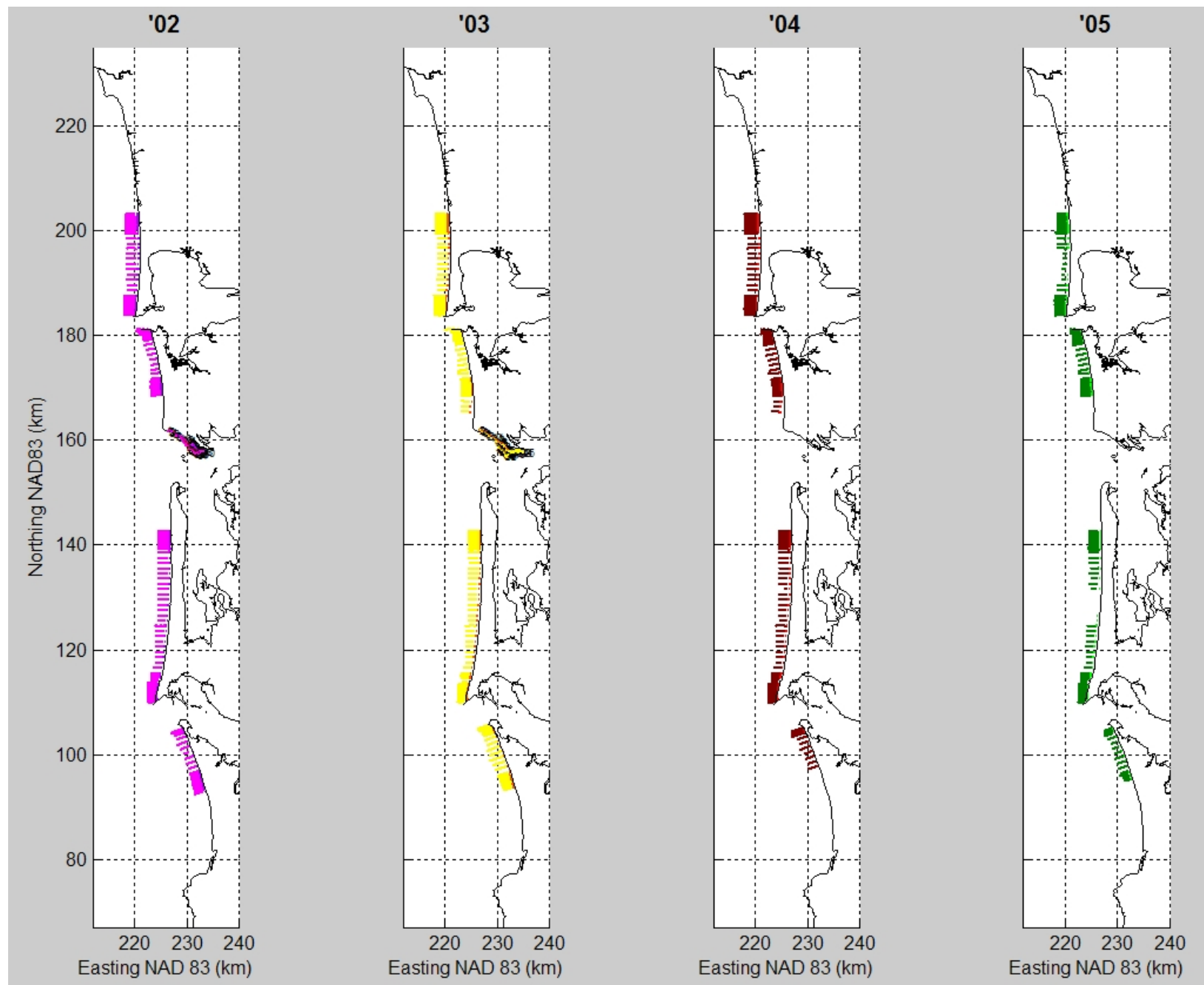

Figure 21. Nearshore bathymetry profiles collected from 2002-2005 in each of the four sub cells.

\section{PRELIMINARY OBSERVATIONS}

We have employed a nested sampling scheme to quantify the alongshore variability of a variety of beach state parameters as well as the short- to medium-term (seasonal to interannual) beach change rates along the CRLC. The following sections discuss the morphodynamic variability along the CRLC found during the first 8 years of the monitoring program. 


\subsection{Beach State Parameters}

Data from the monitoring program provide a regional inventory of physical parameters that help define the morphological 'state' of the beach. The beaches of the CRLC are comprised primarily of well-sorted medium to fine sand with a temporal and alongshore-averaged median mid-beach grain size of approximately $0.20 \mathrm{~mm}$ (ranging from 0.12 to $0.71 \mathrm{~mm}$ within the littoral cell with a standard deviation of $0.11 \mathrm{~mm}$ ). Extensive black-sand placer deposits exist on the beaches adjacent to the mouth of the Columbia River accounting for up to $70 \%$ of most samples ( $\mathrm{Li}$ and Komar, 1991). While there is a coarsening of sediments with increasing distance from the source within approximately the first $10 \mathrm{~km}$ north of the Columbia River, the general trend suggests grain sizes decrease with increasing distance from the Columbia River (Figure 22, Table 16). This trend of alongshore sorting is interrupted near the mouth of Grays Harbor, where coarse sediment lag deposits (derived from glacial outwash and eroded from the shoreface) exist on the beach. Eliminating the two sites (Worm and Spice) that contain this coarse sediment lag reduces the median mid-beach ( $\sim \mathrm{MHW})$ grain size to approximately $0.18 \mathrm{~mm}$.

The sediment size trend is well correlated to a gradient in foreshore beach slope, with slopes decreasing with distance from the Columbia River. The slope of the sub-aerial beach, $\underline{\beta}_{\mathrm{fs}}$, is defined as the gradient between the 1.0 and $3.0 \mathrm{~m}$ elevation contours on the beach profiles, and here we have taken the temporal mean of several summer values at each site, typically 6 observations from $1997-2002$. The mean foreshore beach slope in the CRLC is approximately $0.021(1 \mathrm{~V}: 48 \mathrm{H})$, ranging from $0.01(1 \mathrm{~V}: 100 \mathrm{H})$ to $0.055(1 \mathrm{~V}: 18 \mathrm{H})$ with a standard deviation of 0.008 (Table 3). The northern portion of the North Beach sub-cell exhibits the finest grain sizes and the lowest sloping beaches within the CRLC.

Large-scale coastal behavior varies along the CRLC as evidenced by variability in foredune ridge morphology, nearshore beach slopes, and morphometric bar parameters (Ruggiero et al., 2005). The highest primary foredune ridges, as measured in summer 1997, are in the Clatsop Plains sub-cell, with dunes elevations measuring as high as $15 \mathrm{~m}$ (NAVD 88). North of the Columbia River foredune ridges are distinctly lower, with the lowest primary dune elevations in the northern section of the North Beach sub-cell, where small incipient dunes less than $5 \mathrm{~m}$ (NAVD 88) have formed in front of the backing sea cliffs and bluffs (Figure 22). The cause for 
this variability in foredune height is probably most closely linked to variability in decadal scale shoreline change rates along the CRLC. While the shoreline along Clatsop Plains has remained relatively stable since the 1950s (Kaminsky et al., 1999), the beaches along much of Long Beach and North Beach sub-cells prograded at several meters per year during this time period. Following the conceptual model of foredune morphology described by Hesp (2002), stable beaches tend to build dunes vertically while prograding beaches build a series of foredune ridges over time.

Sandbars are also prominent morphological features within the CRLC and the spatial and temporal variability of bar properties is striking. The CRLC nearshore exhibits between 0 and 4 distinct sandbars, ranging in height from approximately $0.1 \mathrm{~m}$ (measurement limit) to a remarkable $6.0 \mathrm{~m}$ as measured from the seaward crest to landward trough. Sandbar crest position varies from approximately $100 \mathrm{~m}$ from the shoreline (approximated here by the $3.0 \mathrm{~m}$ contour position) for intertidal slip face ridges to over $1000 \mathrm{~m}$ from the shoreline for subtidal outer bars. The water depth at the crest of the outer bar ranges from -3.0 to -8.5 m (NAVD88) while crest depths are typically -1.5 to $-3.0 \mathrm{~m}$ (NAVD88) for middle bars and +2.0 to $-1.5 \mathrm{~m}$ (NAVD88) for intertidal bars.

Nearshore slopes and morphometric bar parameters are summarized in Figure 23 for data collected during summer 2002. The water depths $1500 \mathrm{~m}$ from the shoreline (3.0 m contour), a proxy for nearshore slope, are relatively shallow where profiles intersect the lobes of ebb-tidal deltas near the mouth of the Columbia River, Willapa Bay, and Grays Harbor. Away from estuary entrances, the nearshore slope decreases with distance from the Columbia River. Bar behavior along Long Beach is different than along the other sub-cells because the outer bar is further from the shoreline and in deeper water. The 2002 Long Beach middle bar is larger in amplitude than any other bars within the CRLC. Along the southern $10 \mathrm{~km}$ of the Long Beach sub-cell, there is a correlation between nearshore beach slope and outer bar position with steeper beaches (deeper water at $1500 \mathrm{~m}$ ) having outer bars further from the shoreline (Figure 23). 
a)

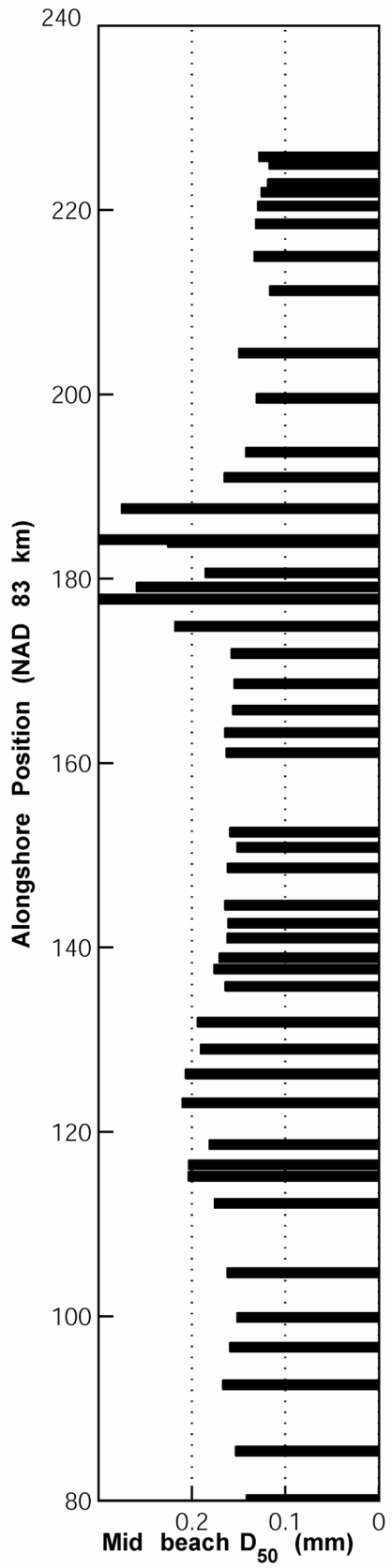

b)

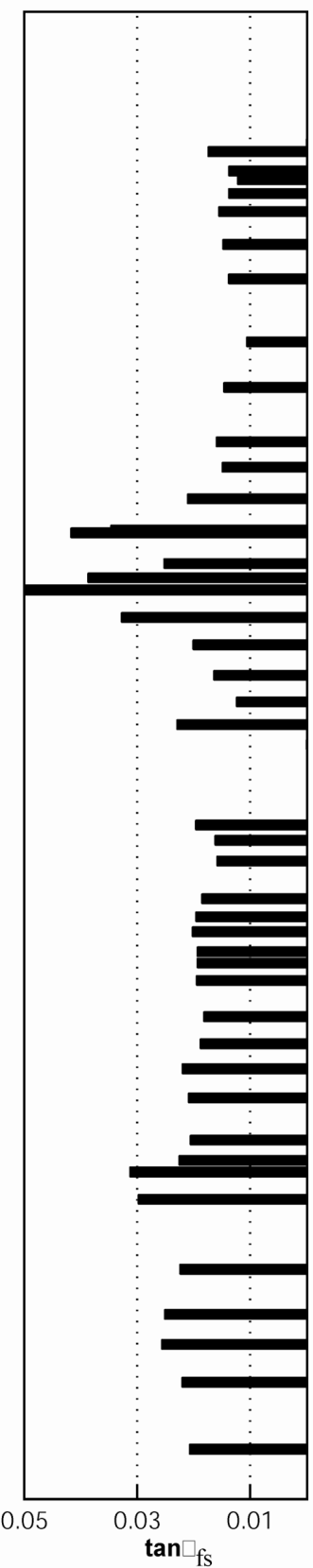

c)

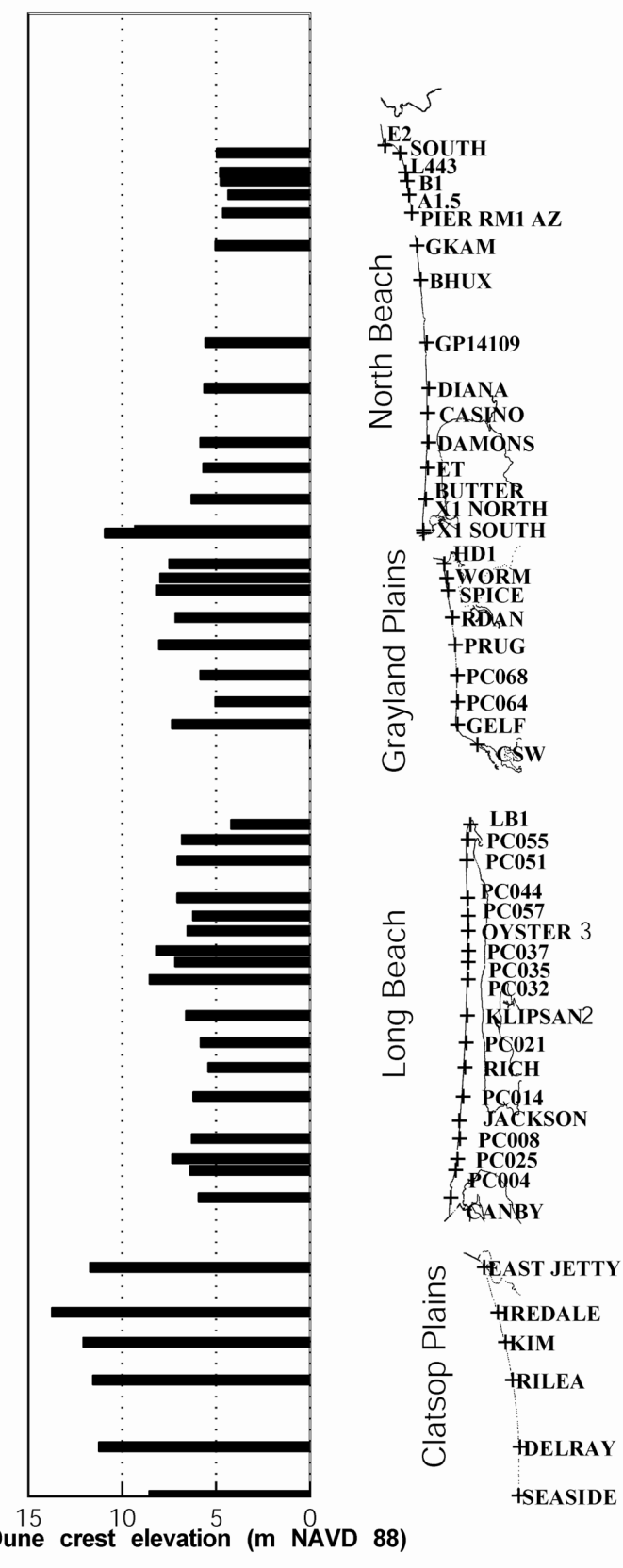

Figure 22. Beach state parameters along the CRLC. a) The average median grain size from samples collected at approximately MHW during both the summer 1998 and summer 1999 survey are shown. b) The slope of the sub-aerial beach as defined as the gradient between the 1.0 and $3.0 \mathrm{~m}$ elevation contours on the profile. Slope values have been averaged for 6 summer surveys collected between 1997 and 2002 at each of the 47 beach profile locations. c) The primary dune crest elevation, as measured in summer 1997, is given relative to NAVD 88. 


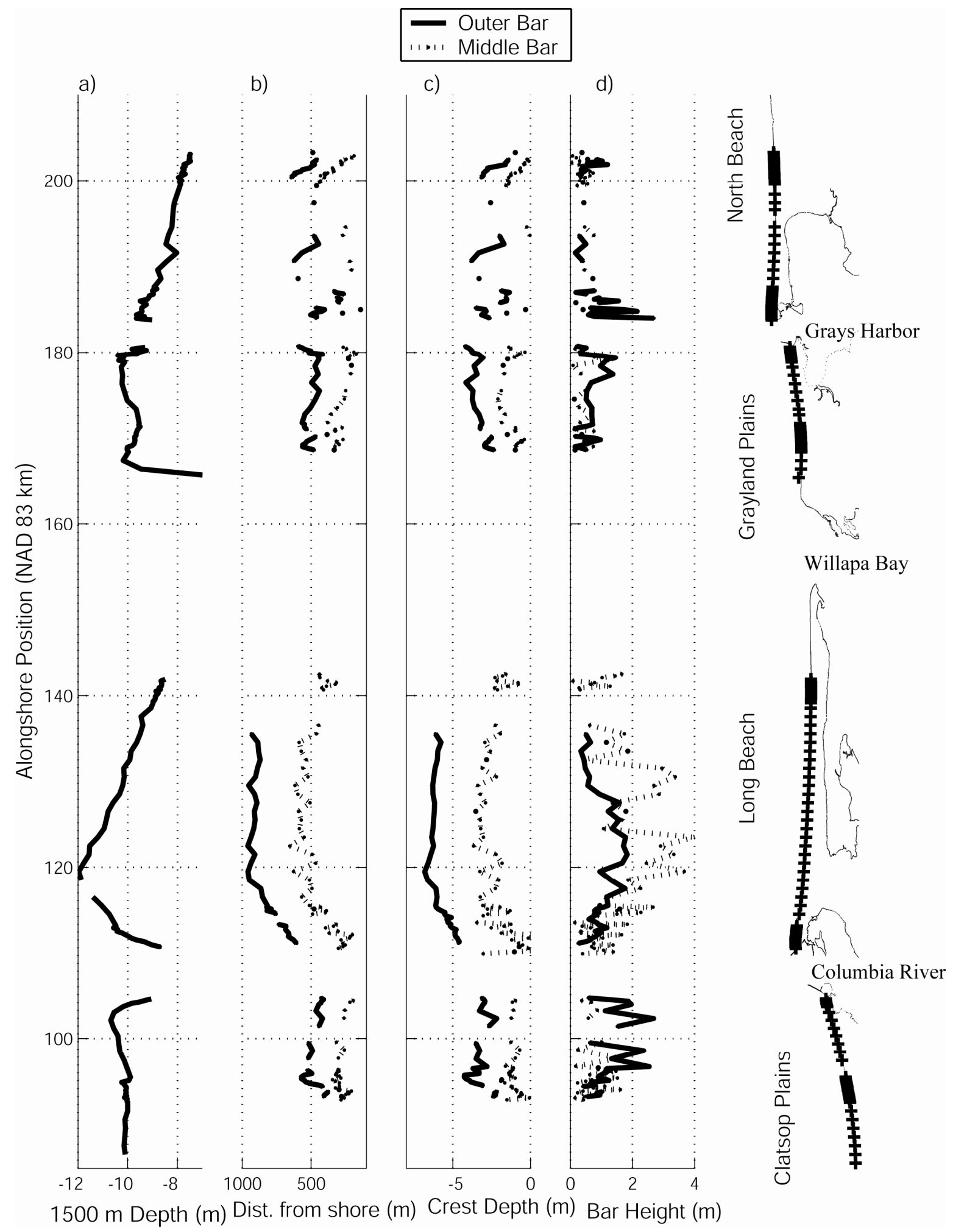

Figure 23. Bathymetric beach state parameters (summer 2002). a) A regional inventory of nearshore beach slope represented by the water depth $1500 \mathrm{~m}$ from the $3.0 \mathrm{~m}$ contour, b) the position of sandbar (outer and inner) crests, c) sandbar crest depths, and d) sandbar heights. The plusses on the map of the littoral cell indicate where nearshore beach profiles are collected. 


\subsection{Seasonal to Interannual Beach Change}

The sub-aerial topographic beach profiles and surface maps are used to quantify the seasonal cycles in the sub-aerial beach of the CRLC. The average horizontal retreat of the shoreline (3.0 $\mathrm{m}$ contour) for each of the profiles and surface maps during each winter season as well as the average horizontal recovery during each summer season is listed in Table 16 and 17 respectively. As a result of the seasonal reversals in cross-shore and alongshore sand transport directions, the net change of the shoreline position over the full annual cycle is often small relative to the seasonal variability (Figure 24). However, the interannual change rates can be significant, particularly near estuary entrances (Figure 25, Table 16, Table 17). The average net shoreline change rate as determined from the beach profiles over eight years of survey data is 5.37 meters per year of progradation. The average net shoreline change rate as determined from the surface maps over eight years of survey data is 2.5 meters per year of progradation. This discrepancy can be explained by several beach profiles with high progradation rates near estuary entrances.

\subsection{Future Directions}

The beach morphology monitoring program of the SWCES has for the first time comprehensively and systematically quantified the short- to medium-term morphodynamic variability of the $165 \mathrm{~km}$-long Columbia River littoral cell. The sampling scheme, nested both in time and space, is successfully resolving the seasonal cycles of beach loss and recovery. Variations in upper shoreface slopes, foredune ridge morphologies, and sandbar dimensions document the extent of alongshore variability in large-scale coastal behavior not previously known to exist in U.S. Pacific Northwest littoral cells or on high-energy dissipative beaches in general. Continued research on the variability in beach behavior across multiple scales is important for both an improved understanding of large-scale coastal behavior and coastal management decision-making. While important alongshore differences in sub-regional coastal behavior have been found, future work aims to examine the primary causative processes, e.g., sediment supply, shoreface morphology, and wave climate, responsible for these differences. 


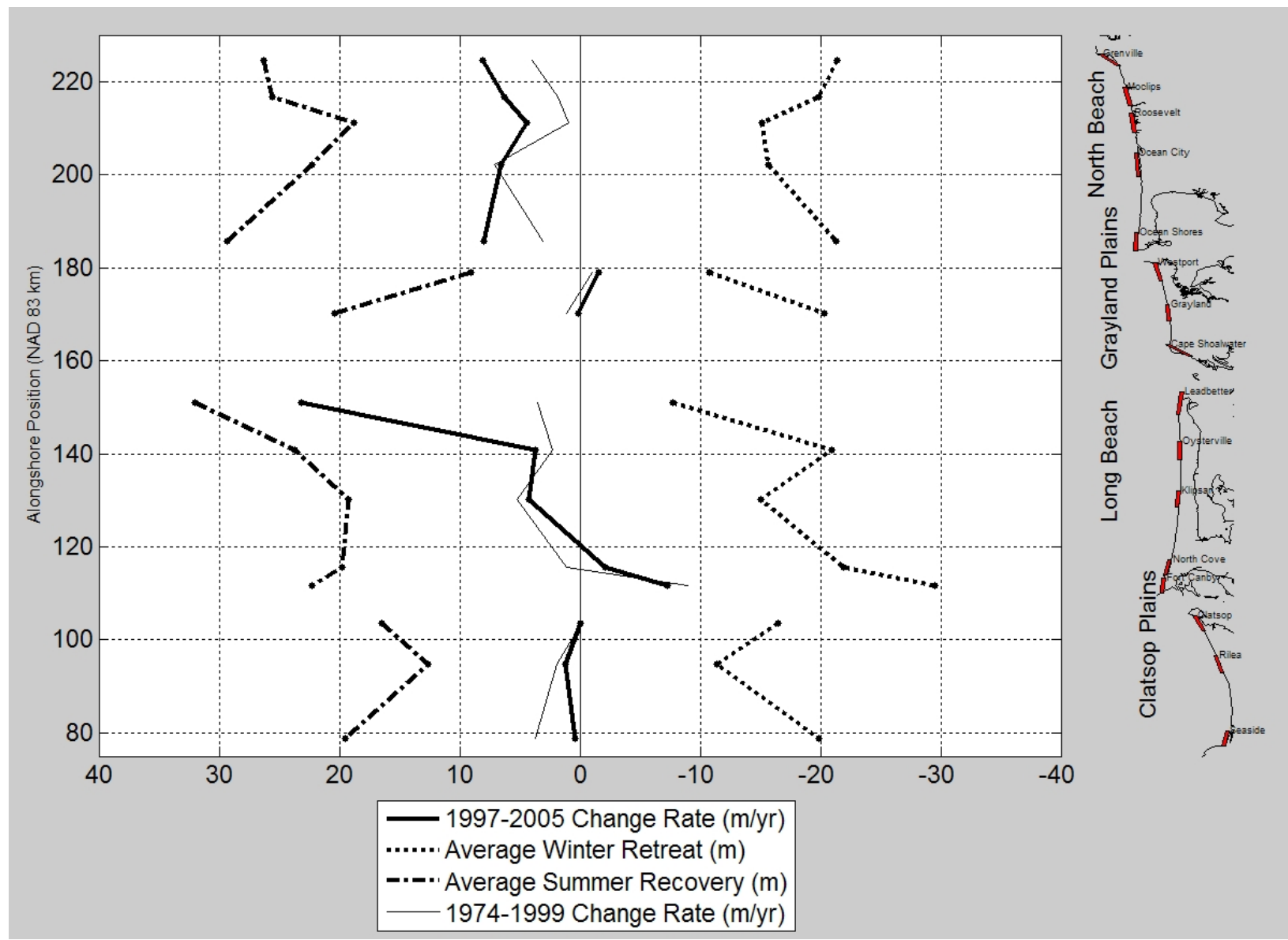

Figure 24. Seasonal- interannual shoreline (contour) variability. The average winter erosion and average summer progradation of the $3.0 \mathrm{~m}$ contour line derived from 15 of the 16 beach surface maps between 1997 and 2005. These large seasonal fluctuations produce low net annual shoreline change rates. Recent interannual shoreline change rates are similar to decadal-scale shoreline change observed between 1974 and 1999 (Kaminsky et al., 1999). 


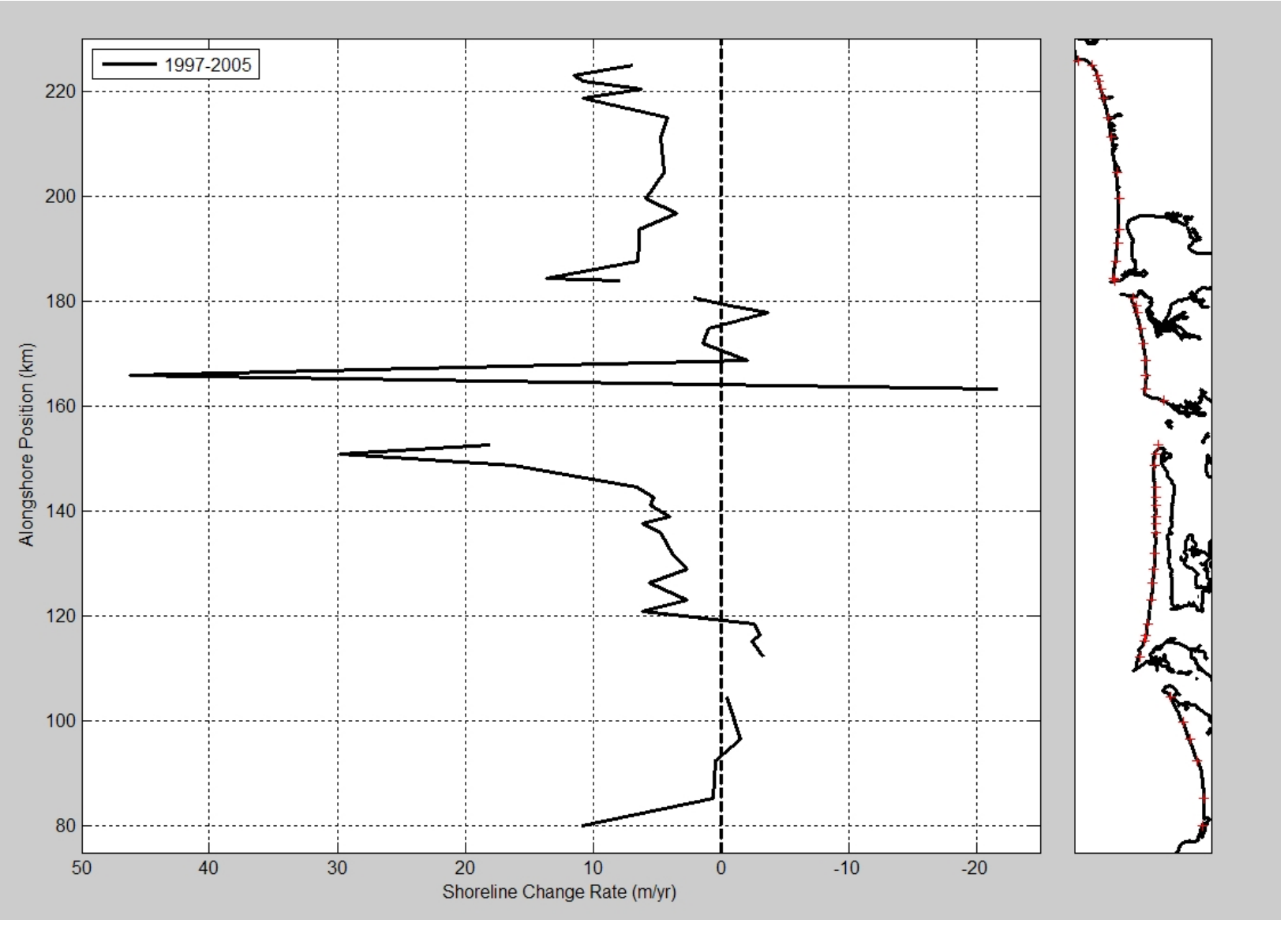

Figure 25. Interannual shoreline change rate determined from sub-aerial topographic beach profiles collected from 1997-2005.

Table 16. Beach profile name, location, 3.0-m contour change rate, beach slope and sediment size.

\begin{tabular}{|c|c|c|c|c|c|c|c|c|}
\hline $\begin{array}{c}\text { Profile } \\
\#\end{array}$ & $\begin{array}{l}\text { Profile } \\
\text { Name }\end{array}$ & $\begin{array}{c}\text { Northing } \\
\text { (m NAD 83) }\end{array}$ & $\begin{array}{c}\text { Winter } \\
\text { Retreat } \\
\text { (m) }\end{array}$ & $\begin{array}{c}\text { Summer } \\
\text { Recovery } \\
\text { (m) }\end{array}$ & $\begin{array}{c}\text { Net Change } \\
(1997-2005) \\
(\mathrm{m})\end{array}$ & $\begin{array}{c}\text { Change } \\
\text { Rate } \\
\text { (m/yr) }\end{array}$ & $\begin{array}{c}\text { Foreshore } \\
\text { Beach } \\
\text { Slope } \\
\end{array}$ & $\begin{array}{c}D_{50} \\
(\mathbf{m m})\end{array}$ \\
\hline 1,41 & E2 & 225785 & --- & --- & -- & --- & --- & --- \\
\hline 2 & SOUTH & 224955 & -5.82 & 13.64 & 54.63 & 6.83 & 0.014 & 0.125 \\
\hline 3 & L443 & 222878 & -17.47 & 34.33 & 91.74 & 11.47 & 0.013 & 0.119 \\
\hline 4 & B1 & 221946 & -13.54 & 25.43 & 86.14 & 10.77 & 0.012 & 0.126 \\
\hline 5 & A 1.5 & 220447 & -2.39 & 23.50 & 49.46 & 6.18 & 0.014 & 0.129 \\
\hline 6 & PIER RM1 AZ & 218502 & -17.01 & 21.93 & 86.14 & 10.77 & 0.015 & 0.137 \\
\hline 7 & GKAM & 214973 & -14.55 & 18.19 & 32.92 & 4.11 & 0.014 & 0.139 \\
\hline 8 & BHUX & 211270 & -5.91 & 6.46 & 37.69 & 4.71 & 0.014 & 0.126 \\
\hline${ }^{2,4} 9$ & GP-14109 & 204507 & --- & 26.04 & 35.42 & 4.43 & 0.010 & 0.156 \\
\hline 10 & DIANA & 199582 & -10.32 & 17.92 & 46.67 & 5.83 & 0.015 & 0.139 \\
\hline 11 & DAMONS & 193730 & -7.18 & 15.89 & 51.02 & 6.38 & 0.016 & 0.151 \\
\hline 12 & ET & 191001 & -8.51 & 15.96 & 51.10 & 6.39 & 0.014 & 0.176 \\
\hline
\end{tabular}




\begin{tabular}{|c|c|c|c|c|c|c|c|c|}
\hline 13 & BUTTER & 187598 & -12.84 & 27.67 & 51.76 & 6.47 & 0.020 & 0.249 \\
\hline 14 & X1 NORTH & 184256 & -19.91 & 36.60 & 108.80 & 13.60 & 0.033 & 0.300 \\
\hline 15 & X1 SOUTH & 183946 & -21.41 & 27.28 & 62.70 & 7.84 & 0.040 & 0.226 \\
\hline 16 & HD-1 & 180649 & -4.33 & 11.39 & 16.48 & 2.06 & 0.025 & 0.179 \\
\hline 17 & WORM & 179096 & -11.05 & 11.50 & -5.97 & -0.75 & 0.039 & 0.599 \\
\hline 18 & SPICE & 177788 & -4.51 & 0.54 & -29.35 & -3.67 & 0.055 & 0.714 \\
\hline 19 & RDAN & 174837 & -4.41 & 8.81 & 7.43 & 0.93 & 0.033 & 0.209 \\
\hline 20 & PRUG & 171889 & -10.38 & 11.35 & 11.13 & 1.39 & 0.020 & 0.169 \\
\hline 21 & PC068 & 168608 & -19.24 & 17.67 & -16.97 & -2.12 & 0.016 & 0.161 \\
\hline${ }^{4} 22$ & PC064 & 165743 & 29.81 & 24.29 & 369.94 & 46.24 & 0.013 & 0.165 \\
\hline${ }^{4} 23$ & GELF & 163300 & -38.52 & 14.58 & -173.93 & -21.74 & 0.023 & 0.188 \\
\hline${ }^{1,4} 24$ & CSW & 161117 & --- & --- & --- & --- & --- & -- \\
\hline${ }^{4} 25$ & LB1 & 152508 & -5.87 & 21.39 & 143.94 & 17.99 & 0.016 & 0.169 \\
\hline${ }^{4} 26$ & PC055 & 150870 & -0.72 & 27.79 & 238.13 & 29.77 & 0.015 & 0.162 \\
\hline 27 & PC051 & 148631 & -14.12 & 29.48 & 129.60 & 16.20 & 0.016 & 0.169 \\
\hline 28 & PC044 & 144588 & -13.49 & 19.88 & 52.17 & 6.52 & 0.019 & 0.171 \\
\hline 29 & PC057 & 142638 & -15.93 & 22.23 & 41.63 & 5.20 & 0.020 & 0.168 \\
\hline 30 & OYSTER 3 & 141023 & -11.82 & 20.30 & 43.67 & 5.46 & 0.020 & 0.173 \\
\hline 31 & PC037 & 138871 & -11.47 & 13.77 & 32.08 & 4.01 & 0.019 & 0.180 \\
\hline 32 & PC035 & 137661 & -6.56 & 15.94 & 48.70 & 6.09 & 0.019 & 0.185 \\
\hline 33 & $\mathrm{PC} 032$ & 135789 & -13.49 & 18.95 & 37.56 & 4.70 & 0.019 & 0.178 \\
\hline 34 & KLIPSAN 2 & 131891 & -16.61 & 21.59 & 30.58 & 3.82 & 0.018 & 0.196 \\
\hline 35 & $\mathrm{PC} 021$ & 128971 & -13.81 & 22.39 & 21.12 & 2.64 & 0.018 & 0.197 \\
\hline 36 & $\mathrm{RICH}$ & 126285 & -15.91 & 21.96 & 44.79 & 5.60 & 0.022 & 0.214 \\
\hline 37 & PC014 & 123150 & -15.50 & 19.09 & 20.99 & 2.62 & 0.021 & 0.216 \\
\hline 38 & PC008 & 118599 & -20.83 & 18.10 & -21.07 & -2.63 & 0.020 & 0.187 \\
\hline 39 & $\mathrm{PC} 025$ & 116433 & -14.97 & 13.22 & -24.42 & -3.05 & 0.022 & 0.206 \\
\hline 40 & PC004 & 115183 & -13.36 & 12.10 & -19.52 & -2.44 & 0.030 & 0.206 \\
\hline 41 & CANBY & 112242 & -14.42 & 16.75 & -27.07 & -3.38 & 0.030 & 0.187 \\
\hline 42 & EAST JETTY 2 & 104717 & -1.85 & 12.15 & -3.73 & -0.47 & 0.022 & 0.165 \\
\hline 43 & IREDALE & 99862 & -14.03 & 14.69 & -8.66 & -1.08 & 0.024 & 0.163 \\
\hline 44 & KIM & 96632 & -13.37 & 13.81 & -12.40 & -1.55 & 0.025 & 0.167 \\
\hline 45 & RILEA & 92558 & -10.16 & 11.83 & 3.14 & 0.39 & 0.022 & 0.174 \\
\hline 46 & DELRAY & 85353 & -11.18 & 12.56 & 4.92 & 0.61 & 0.021 & 0.163 \\
\hline 47 & SEASIDE RM2 & 80086 & -16.89 & 35.76 & 87.12 & 10.89 & 0.015 & 0.151 \\
\hline${ }^{3,4} 48$ & CASINO & 196608 & 2.87 & 13.29 & 54.53 & 10.91 & --- & -- \\
\hline \multirow[t]{5}{*}{3,449} & JACKSON & 120901 & -11.91 & 21.53 & 28.34 & 5.67 & --- & --- \\
\hline & & Average & -11.19 & 18.76 & 41.94 & 5.37 & 0.021 & 0.196 \\
\hline & & Std & 9.18 & 7.43 & 76.24 & 9.56 & 0.008 & 0.107 \\
\hline & & Max & 29.81 & 36.60 & 369.94 & 46.24 & 0.055 & 0.714 \\
\hline & & Min & -38.52 & 0.54 & -173.93 & -21.74 & 0.010 & 0.119 \\
\hline
\end{tabular}

${ }^{1}$ Profiles 2 and 24 were discontinued in spring 2000, due to bad GPS satellite visibility, and winter 2000, due to a beach fill, respectively.

${ }^{2}$ Profile 9 was impacted by the northerly migration of a coastal stream in 1999.

${ }^{3}$ Profiles 48 and 49 were begun in fall 1999 and winter 2000 respectively.

${ }^{4}$ Profiles 2, 9, 22, 23, 24, 25, 26, 48, and 49 have not been included in the 5-year averages. 
Table 17. Alongshore averaged change rates of the $3.0 \mathrm{~m}$ contour calculated for each of the 16 topographic beach surface maps.

\begin{tabular}{|c|c|c|c|c|c|c|}
\hline $\begin{array}{c}\text { Surface } \\
\text { Map } \\
\# \\
\end{array}$ & $\begin{array}{c}\text { Surface Map } \\
\text { Name }\end{array}$ & $\begin{array}{c}\text { Northing } \\
\text { (m NAD 83) }\end{array}$ & $\begin{array}{c}\text { Winter } \\
\text { Retreat (m) }\end{array}$ & $\begin{array}{c}\text { Summer } \\
\text { Recovery (m) }\end{array}$ & $\begin{array}{c}\text { Net Change } \\
\text { Rate 1997-2005 } \\
\text { (m/yr) }\end{array}$ & $\begin{array}{c}\text { Shoreline Change } \\
\text { 1974-1999² }^{2} \\
\text { (m/yr) }\end{array}$ \\
\hline 1 & Grenville & 225862 & -21.4 & 26.3 & 8.1 & 4.0 \\
\hline 2 & Moclips & 218742 & -19.9 & 25.6 & 6.3 & 1.8 \\
\hline 3 & Roosevelt & 213117 & -15.1 & 18.8 & 4.4 & 0.9 \\
\hline 4 & Ocean City & 204655 & -15.7 & 22.3 & 6.6 & 7.1 \\
\hline 5 & Ocean Shores & 187583 & -21.3 & 29.3 & 8.0 & 3.1 \\
\hline 6 & Westport & 181088 & -10.8 & 9.1 & -1.6 & -1.0 \\
\hline 7 & $\begin{array}{l}\text { Grayland } \\
{ }^{1} \text { Cape }\end{array}$ & 171987 & -20.3 & 20.4 & 0.1 & 1.1 \\
\hline 8 & Shoalwater & 163419 & -52.8 & 23.4 & -9.4 & --- \\
\hline 9 & Leadbetter & 153229 & -7.7 & 32.0 & 23.2 & 3.5 \\
\hline 10 & Oysterville & 142715 & -20.9 & 23.7 & 3.7 & 2.3 \\
\hline 11 & Klipsan & 131964 & -15.0 & 19.2 & 4.2 & 5.2 \\
\hline 12 & North Head & 117127 & -21.9 & 19.8 & -2.1 & 1.1 \\
\hline 13 & Ft. Canby & 113280 & -29.5 & 22.3 & -7.3 & -9.0 \\
\hline 14 & Clatsop Spit & 105159 & -16.5 & 16.5 & 0.0 & -0.1 \\
\hline 15 & Rilea & 96593 & -11.4 & 12.6 & 1.2 & 1.9 \\
\hline \multirow[t]{5}{*}{16} & Seaside & 80395 & -19.9 & 19.5 & 0.4 & 3.7 \\
\hline & & Average & -19.9 & 21.0 & 2.5 & 1.7 \\
\hline & & STD & 10.6 & 5.8 & 7.5 & 3.6 \\
\hline & & MAX & -7.7 & 32.0 & 23.2 & 7.1 \\
\hline & & MIN & -52.8 & 9.1 & -9.4 & -9.0 \\
\hline
\end{tabular}

${ }^{1}$ Cape Shoalwater surface map data is not included in the calculations of regional statistics due to the influence of inlet processes at Willapa Bay.

${ }^{2}$ Shorelines presented in Kaminsky et al., 1999. 


\section{REFERENCES}

Allan, J.C. and Komar, P.D., 2000. Spatial and temporal variations in the wave climate of the North Pacific, Report to the Oregon Department of Land Conservation and Development $46 \mathrm{p}$.

Allan, J.C. and Komar, P.D., 2002 Extreme storms in the Pacific Northwest coast during the 1997-98 El Niño and 1998-99 La Niña, Journal of Coastal Research, 18, 1, pp. 175-193.

Atwater, B.F., Nelson, A.R., Claque J.J., Yamaguchi, D.K., Dobrowsky, P.T., Bourgeois, J., Darienzo, M.E., Grant, W.C., Hemphill-Haley, E., Kelsey, H.M., Jacoby, G.C., Nichenko, S.P, Palmer, S.P., Peterson, C.D., and Reinhart, M.A., 1995. Summary of coastal geological evidence for past great earthquakes at the Cascadia subduction zone. Earthquake Spectra, 11, 1-18.

Beach, R.A., Holman, R.A., and Stanley, J., 1996. Measuring nearshore bathymetry on high energy beaches. American Geophysical Union Fall Meeting, 1996, F286.

Birkemeier, W. A., and Mason, C., 1984. The CRAB: A Unique nearshore Surveying Vehicle. Journal of Surveying Engineering, 110(1), 1-7.

Buijsman, M.C., Kaminsky, G.M., and Gelfenbaum, G., 2003. Shoreline change associated with jetty construction, deterioration, and rehabilitation at Grays Harbor, Washington, Shore and Beach, 71, 15-22.

Coastal Data Information Program. University of California, San Diego. http://cdip.ucsd.edu/.

Cote, J.M., 1999. The measurement of nearshore bathymetry on Intermediate and dissipative beaches. Unpublished Masters Thesis, Oregon State University, Corvallis, Oregon, 102 pp.

Daniels, R.C., Ruggiero, P., and Weber, L.E., 1999. Washington coastal geodetic control network: report and station index, Washington Department of Ecology, Coastal Monitoring \& Analysis Program, Publication \#99-103, 268 p.

Daniels, R.C, McCandless, D. C., Huxford, R.H., Kingsley, E.D. and Ruggiero, P., 2001. 2001 Update to the Washington Coastal Geodetic Control Network, Developed in Support of the Southwest Washington Coastal Erosion Study. Washington Department of Ecology, Coastal Monitoring \& Analysis Program Publication No. 01- 06-013, 22 p.

Gelfenbaum, G., Kaminsky, G.M., Sherwood, C.R., and Peterson, C.D. 1997. Southwest Washington coastal erosion workshop report, U.S. Geological Survey Open File Report 97-471, $102 \mathrm{p}$. 
Gelfenbaum, G., Sherwood, C.R., Kerr, L.A., and Kurrus, K., 2000. Grays Harbor wave refraction experiment 1999: Data report, US Geological Survey Open File Report, OF 0044, 132 pp.

Gelfenbaum, G., Buijsman, M.C., Sherwood, C.R., Moritz, H.R., and Gibbs, A.E., 2001. Coastal evolution and sediment budget at the mouth of the Columbia River, USA, Proceedings of Coastal Dynamics ’01, ASCE, 818-827.

Hesp, P., 2002. Foredunes and blowouts: initiation, geomorphology and dynamics. Geomorphology, 48, 245-268.

Kaminsky, G.M., Ruggiero, P., Gelfenbaum, G., and Peterson, C., 1997. Long-term coastal evolution and regional dynamics of a US Pacific Northwest littoral cell, Proceedings of Coastal Dynamics '97, ASCE, pp. 614-623.

Kaminsky, G.M., Ruggiero, P., and Gelfenbaum, G., 1998. Monitoring coastal change in southwest Washington and northwest Oregon during the 1997/98 El Niño, Shore \& Beach, pp. 42 - 51.

Kaminsky, G.M., Buisjman, M.C., Gelfenbaum, G., Ruggiero, P., Jol, H.M., Gibbs, A.E., and Peterson, C.D., 1999. Synthesizing geological observations and processes-response data for modeling coastal change at management scale, Proceedings of Coastal Sediments '99, ASCE, pp. 1708-1723.

Kaminsky, G.M., Buijsman, M.C., and Ruggiero, P., 2001. Predicting shoreline change at decadal scale in the Pacific Northwest, USA, Proceedings of The International Conference on Coastal Engineering, 2000.

Komar, P.D., 1986. The 1982-83 El Niño and erosion on the Oregon coast. Shore and Beach, 54, 3-12.

Komar, P.D., Allan, J., Dias-Mendez, G.M., Marra, J.J., and Ruggiero, P. 2000. El Niño and LaNiña: Erosion processes and impacts, Proceedings of the 27th International Conference on Coastal Engineering, ASCE, Sydney, Australia, pp. 2414-2427.

Li, M.Z. and Komar, P.D., 1991. Longshore grain sorting and beach placer formation adjacent to the Columbia River. Journal of Sedimentary Petrology, 62(3), 429-441.

MacMahan, J., 2001. Hydrographic surveying from a personal watercraft. Journal of Surveying Engineering,127(1), 12-24.

Meyers, R.A., Smith, D.G., Jol, H.M., and Peterson, C.D., 1996. Evidence for eight great earthquake-subsidence events detected with ground penetrating radar, Willapa Barrier, Washington, Geology, 24(2), 99-102.

Morton, R.A.; Leach, M.P., Paine, J.G., and Cardoza, M.A., 1993. Monitoring beach changes 
using GPS surveying techniques. Journal of Coastal Research, 9(3), 702-720.

National Data Buoy Center. National Oceanic and Atmospheric Administration.

http://www.ndbc.noaa.gov/index.shtml.

National Oceanic and Atmospheric Administration. Tide and Current Data. http://tidesandcurrents.noaa.gov/station_retrieve.shtml?type=Tide\%20Data\&sort=A.STA TION_ID\&state $=\& i d 1=$.

Peterson, C.D., Jackson, P.L., Oneill, D.J., Rosenfeld, C.L., and Kimerling, A.J., 1990. Littoral call response to interannual climatic forcing 1983-1987 on the central Oregon coast, USA. Journal of Coastal Research, 6(1), 87-110

Ruggiero, P., Kaminsky, G.M., and Plant, N.G., 1998. Coastal morphologic variability of high energy dissipative beaches, $26^{\text {th }}$ International Conference on Coastal Engineering, Copenhagen, DK, pp. 2793-2804.

Ruggiero, P., Cote, J., Kaminsky, G.M., and Gelfenbaum, G., 1999. Scales of variability along the Columbia River Littoral Cell, Proceedings of Coastal Sediments '99, ASCE, pp. 1692-1707.

Ruggiero, P. and Voigt, B., 2000. Beach monitoring in the Columbia River Littoral Cell, $1997-$ 2000, Publication No. 00-06-26, Coastal Monitoring \& Analysis Program, Washington Department of Ecology, Olympia, WA, 112 p.

Ruggiero, P., Kaminsky, G.M., Gelfenbaum, G., 2003. Linking proxy-based and datum-based shorelines on high-energy coastlines: Implications for shoreline change analyses. Journal of Coastal Research, SI \#38, 57-82.

Ruggiero, P., Kaminsky, G.M., Gelfenbaum, G., Voigt, B., 2005. Seasonal to interannual morphodynamics along a high-energy dissipative littoral cell. Journal of Coastal Research, 21 (3), 553-578.

Ruggiero, P., Buijsman, M.C., Kaminsky, G., and Gelfenbaum, G., in press. Modelling the effect of wave climate and sediment supply variability on large-scale shoreline change, submitted to Marine Geology.

Sallenger, A.H., Krabill, W.B., Swift, R.N., Brock, J., List, J., Hansen, M., Holman, R.A., Manizade, S., Sontag, J., Meredith, A., Morgan, K., Yunkel, J.K., Frederick, E.B., and Stockdon, H., 2003. Evaluation of airborne topographic lidar for quantifying beach changes. Journal of Coastal Research, 19(1), 125-133.

Stockdon, H.F., Sallenger, A.H., List, J.H., Jr., and Holman, R.A., 2002. Estimation of shoreline position and change using airborne topographic lidar data. Journal of Coastal Research, 18(3), 502-513. 
Tetra Tech Inc., 1986. Recommended protocols for measuring conventional sediment variables in Puget Sound, for the U.S. Environmental Protection Agency, 46 p.

Tillotsen, K.J. and Komar, P.D., 1997. The wave climate of the Pacific Northwest (Oregon and Washington): A comparison of data sources. Journal of Caostal Research, 13, 440-452.

Trimble Navigation Limited, 1998. 4700 Receiver Operation Manual. Version 1.0, Part Number 36238-00, Revision B.

Trimble Navigation Limited, 2004. Trimble R8 GPS System Data Sheet.

UNESCO, 1982. Algorithms for computation of fundamental properties of seawater. 44, Unesco/SCOR/ICES/IAPSO Joint Panel.

Wright, L.D. and Short, A.D. 1983. Morphodynamics of beaches and surf zones in Australia. Handbook of Coastal Processes and Erosion, ed. P.D. Komar, CRC Press, Boca Raton, Florida, 35-64. 


\section{ACKNOWLEDGEMENTS}

This work was funded by the US Geological Survey, the Washington Department of Ecology, and the USGS Mendenhall Postdoctoral Fellowship Program. We thank Laura Bauleke, Jessica Côté, Dawn Harpel, Laura Kerr, Emily Lindstrum, Diana McCandless, Josh McInnes, Jamie MacMahan, Troy Warnick, Andrew Schwartz, Lindsey Doermann and Andrew Stevens who collected the bulk of the data. Maarten Buijsman, Rich Daniels, Steve Eykelhoff, Bob Huxford, Sarah Haque, Dylan Monahan, and Peter Wald were always available when necessary to make sure that we "got the data." This report benefited significantly from review comments by Patrick Barnard and Kathy Presto. 


\section{APPENDIX A.}

The following section provides directions to each of the 49 beach profiles in the monitoring program. The majority of the beach profiles originate well landward of the primary dune. A $4 \times 4$ inch wooden post with a metal name-plate that indicates the profile name typically marks the profile origins. The first (most landward) point of each profile is given in Table 2. Northings and Eastings are presented in NAD $83(\mathrm{~m})$, Washington State Plane South. Many of the profiles are co-located with geodetic control monuments that are well marked with witness posts. All of the profiles extend from the starting point across the dunes at an angle roughly perpendicular to the shoreline. Many of the profiles have 1 or 2 witness posts in the dunes to assist with the profile orientation.

\section{A.1 North Beach Sub-cell}

E2

This site is located in the vicinity of Moclips, Washington, south of Point Grenville on Quinalt Indian Tribal property. This beach is closed to the general public, and access to this site is limited to those with permission to be on tribal land. To reach the site, proceed north on SR109 from Moclips. Take the last beach access road off of SR109 before Point Grenville. The profile location is approximately $500 \mathrm{~m}$ $(1640 \mathrm{ft})$ north of the beach access road. The monument associated with this profile is located on Point Grenville.

\section{SOUTH}

This site is located in the vicinity of Moclips, Washington, south of Point Grenville on Quinalt Indian Tribal property. This beach is closed to the general public, and access to this site is limited to those with permission to be on tribal land. To reach the site, proceed north on SR109 from Moclips. Take the last beach access road off of SR109 before Point Grenville. The profile location is approximately $200 \mathrm{~m}$ (656 $\mathrm{ft})$ south of the beach access road. The monument corresponding with this profile is on the beach approximately $100 \mathrm{~m}$ north of the access road on a large rock.

\section{L443}

This site is located in the vicinity of Moclips, Washington, south of Point Grenville on Quinalt Indian Tribal property. This beach is closed to the general public, and access to this site is limited to those with permission to be on tribal land. To reach the site, proceed north on SR109 from Moclips. Take the last beach access road off of SR109 before Point Grenville. The profile location is approximately $2 \mathrm{~km}(1.24$ miles) south of the beach access road. The monument associated with this profile is located on the southwest corner of a bridge just north of the profile on SR109.

\section{B1}

This site is located in the vicinity of Moclips, Washington, south of Point Grenville on Quinalt Indian Tribal property. This beach is closed to the general public, and access to this site is limited to those with permission to be on tribal land. To reach the site, proceed north on SR109 from Moclips. Take the last beach access road off of SR 109 before Point Grenville. The profile location is approximately $3 \mathrm{~km}(1.86$ miles) south of the beach access road. There is no monument in the immediate vicinity of this profile.

\section{A 1.5}

This site is located in the vicinity of Moclips, Washington, south of Point Grenville on Quinalt Indian Tribal property. This beach is closed to the general public, and access to this site is limited to those with 
permission to be on tribal land. To reach the site, proceed north on SR109 from Moclips. Take the last beach access road off of SR109 before Point Grenville. The profile location is approximately $4.5 \mathrm{~km}(2.8$ miles) south of the beach access road. There is no monument in the immediate vicinity of this profile.

\section{PIER RM1 AZ}

This site is located in the vicinity of Moclips, Washington. To reach the site from the post office in Moclips, follow SR 109 north $0.64 \mathrm{~km}\left(0.4\right.$ miles) to $2^{\text {nd }}$ Street (intersection is on the north side of the Moclips River). Continue west on the $2^{\text {nd }}$ Street beach access road. The monument can be found in the southwest corner of a yard just north of $2^{\text {nd }}$ Street and east of a side street. The beach profile is located approximately $50 \mathrm{~m}(164 \mathrm{ft})$ north of the $2^{\text {nd }}$ Street beach access and approximately $50 \mathrm{~m}(164 \mathrm{ft})$ west of the monument.

\section{GKAM}

This site is located in the City of Pacific Beach, Washington, within Pacific Beach State Park. To reach the site from SR109 in Pacific Beach, at the intersection of Ocean Beach Road/Main Street and SR109 proceed west to $2^{\text {nd }}$ Street. Continue south on $2^{\text {nd }}$ Street into Pacific Beach State Park. Travel west inside the State Park, past the restroom, to the beach access parking area. The monument is located at the center of a small traffic circle. The profile begins approximately $110 \mathrm{~m}(361 \mathrm{ft})$ north of the monument in front of the bluff.

\section{BHUX}

This site is located in the vicinity of Roosevelt Beach, south of Pacific Beach, Washington. To reach the site from SR109 in Pacific Beach, follow SR109 south $5.47 \mathrm{~km}$ (3.4 miles) to the intersection with the beach access road at Roosevelt Beach. Continue on the access road to the beach access parking area. The monument is approximately $3 \mathrm{~m}(9.5 \mathrm{ft})$ west of the northwest corner of the small restroom in the parking area. The profile is located approximately $70 \mathrm{~m}(230 \mathrm{ft})$ to the south of the monument, fronting the large sea cliff.

\section{GP-14109}

This site is located in the vicinity of Copalis, Washington in the Griffith-Priday State Park. To reach the site from Ocean City, follow Highway 109 north to Benner Road. Continue west on Benner Road 0.40 $\mathrm{km}(0.25$ miles $)$ to the monument that is just north of Benner Road located on a small grassy mound in the southern end of the beach access parking lot. The profile begins approximately $50 \mathrm{~m}(164 \mathrm{ft})$ northwest of the monument.

\section{DIANA}

This site is located in Ocean City, Washington within Ocean City State Park. To reach the site from the intersection of SR 109 and Route 115, follow SR109 north to $2^{\text {nd }}$ Street in Ocean City. Travel west on $2^{\text {nd }}$ Street into Ocean City State Park. Follow $2^{\text {nd }}$ street west to the beach access parking area on the left. The

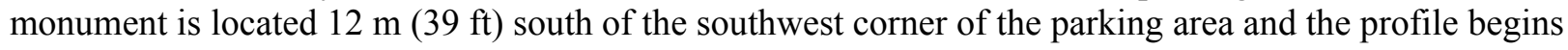
approximately $100 \mathrm{~m}(328 \mathrm{ft})$ west of the monument.

\section{CASINO}

This site is located north of Oyhut State Park in front of the Quinalt Indian Nation Casino. To reach the site from the intersection of Route 115 (Damon Road) and Point Brown Boulevard in Ocean Shores, follow the Damon Road beach access west approximately $745 \mathrm{~m}(2444 \mathrm{ft})$ to the beach. Travel north approximately $2.8 \mathrm{~km}(1.74 \mathrm{miles})$ to the front of the casino. The profile is located $20 \mathrm{~m}(394 \mathrm{ft})$ east in the dune in front of the Casino. There is no monument in the immediate vicinity of this profile. 


\section{DAMONS}

This site is located within Oyhut, Washington in Oyhut State Park. To reach the site from the intersection of Route 115 (Damon Road) and Point Brown Boulevard in Ocean Shores, follow the Damon Road beach access west to the parking area on the left. The monument is located at the east end of the traffic island in

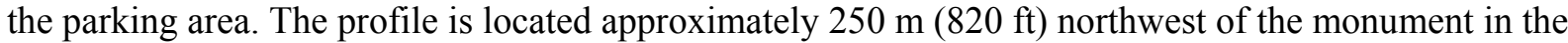
dunes across the street from the Best Western Hotel.

\section{ET}

This site is located within the City of Ocean Shores, Washington. To reach the site from the intersection of Route 115 and Point Brown Avenue, follow Point Brown Avenue south to Chance-A-La-Mer Road. Travel west on Chance-A-La-Mer Road to Ocean Shores Boulevard. Follow Ocean Shores Boulevard south to the Pacific Boulevard beach access road. Travel west on Pacific Boulevard to the end of the road. The monument is located approximately $21 \mathrm{~m}(69 \mathrm{ft})$ south of the centerline of Pacific Boulevard next to a telephone pole in the dune. The profile begins approximately $50 \mathrm{~m}(164 \mathrm{ft})$ southwest of the monument.

\section{BUTTER}

This site is located in the City of Ocean Shores, Washington. To reach the site from Ocean Shores, follow Ocean Shores Boulevard south to the Butter Clam Road beach access. Continue west on Butter Clam Road to the beach access parking area. The monument is located $1 \mathrm{~m}(3.28 \mathrm{ft})$ west of the northwest corner of the parking area. The profile begins approximately $20 \mathrm{~m}(65.6 \mathrm{ft})$ southwest of the monument.

\section{X1 NORTH}

This site is located in the City of Ocean Shores, Washington. To reach the site from Ocean Shores, follow Ocean Shores Boulevard south to the Grays Harbor North Jetty. The profile begins approximately $450 \mathrm{~m}$ $(1476 \mathrm{ft})$ north of the jetty and $10 \mathrm{~m}(33 \mathrm{ft})$ north of the north end of the "wave bumper" rock revetment. This profile intersects the geotubes that were installed in December 1998. The landward edge of the profile is on Ocean Shores Boulevard. The monument associated with this profile is located approximately $200 \mathrm{~m}(656 \mathrm{ft})$ east of the profile in the grass just beyond Ocean Shores Boulevard.

\section{X1 SOUTH}

This site is located in the City of Ocean Shores, Washington. To reach the site from Ocean Shores, follow Ocean Shores Boulevard south to the Grays Harbor North Jetty. The profile begins approximately $150 \mathrm{~m}$ $(492 \mathrm{ft})$ north of the jetty and $10 \mathrm{~m}(33 \mathrm{ft})$ south of the south end of the "wave bumper" rock revetment. The landward edge of the profile is on Ocean Shores Boulevard. The monument associated with this profile can be found approximately $50 \mathrm{~m}(165 \mathrm{ft})$ north of the jetty and approximately $50 \mathrm{~m}(164 \mathrm{ft})$ west of Ocean Shores Boulevard.

\section{A.2 Grayland Plains Sub-cell}

\section{HD-1}

This site is located in the City of Westport, Washington in Westhaven State Park. To reach the site from the intersection of SR105 and SR105 Spur, follow SR105 Spur north to the Ocean Avenue beach access road. Continue east on Ocean Avenue to Montesano Avenue. Head north on Montesano Avenue to the Westhaven State Park beach access road. Follow the beach access road $1.61 \mathrm{~km}$ (1.0 miles) to the beach access parking area. On the west side of the parking area is a wood-frame restroom. The monument is located $28 \mathrm{~m}(92 \mathrm{ft})$ west of the northwest corner of the restroom and $262 \mathrm{~m}(860 \mathrm{ft})$ south of the Grays Harbor South Jetty. The profile begins approximately $160 \mathrm{~m}(525 \mathrm{ft})$ south of the monument.

\section{WORM}


This site is located in the City of Westport, Washington $0.72 \mathrm{~km}(0.45$ miles $)$ southwest of the Westport Lighthouse. To reach the site from the intersection of SR105 and SR105 Spur, follow SR105 Spur north to the Ocean Avenue beach access road. Continue west on Ocean Avenue to the beach access parking area on the north side of the road. Follow the concrete walkway to the monument west of the first wooden platform. The profile begins approximately $70 \mathrm{~m}(230 \mathrm{ft})$ to the south of the monument.

\section{SPICE}

This site is located in the City of Westport, Washington. To reach the site from the intersection of SR105 and SR105 Spur, follow SR105 north to Newell Avenue. Follow Newell Avenue west to Surf Street. Follow Surf Street north to Dunehaven Road. Travel west on Dunehaven Road to Dune Crest Drive, and follow Dune Crest Drive south. The monument is located at the end of the road. The profile begins approximately $20 \mathrm{~m}(66 \mathrm{ft})$ to the south of the monument.

\section{RDAN}

This site is located in the vicinity of Westport, Washington at the southern boundary of Twin Harbors State Park. To reach the site from the intersection of SR105 and SR105 Spur, travel south on SR105 2.25 $\mathrm{km}$ (1.4 miles) to Bonge Avenue. Follow Bonge Avenue west to the beach access parking area. On the west side of the parking lot is a wood-framed restroom. The monument is located $34 \mathrm{~m}(112 \mathrm{ft})$ southwest of the southwest corner of the restroom. The profile begins approximately $20 \mathrm{~m}(66 \mathrm{ft})$ to the west and 13 $\mathrm{m}(43 \mathrm{ft})$ to the north of the monument.

\section{PRUG}

This site is located north of Grayland, Washington. To reach the site from Grayland, go north $0.48 \mathrm{~km}$ ( 0.30 miles) on SR105 to the intersection of SR105 and Marine Drive. Go west on Marine Drive to the intersection of Marine Drive and Salt Air Boulevard. The monument is approximately $4 \mathrm{~m}(13 \mathrm{ft})$ north of the centerline of Marine Drive and $71 \mathrm{~m}(232 \mathrm{ft})$ west of the centerline of Salt Air Boulevard. The profile originates $5 \mathrm{~m}(16.4 \mathrm{ft})$ northeast of the monument.

\section{PC068}

This site is located in the vicinity of Grayland, Washington. To reach the site from the intersection of SR105 and the County Line Road, go west on the County Line Road beach access $0.60 \mathrm{~km}$ (0.37 miles). The monument is located approximately $5 \mathrm{~m}(16.4 \mathrm{ft})$ south of the center line of the access road. The profile begins $3 \mathrm{~m}(9.84 \mathrm{ft})$ south of the monument.

\section{PC064}

This site is located in the vicinity of Grayland, Washington. To reach the site from the intersection of SR105 and Midway Beach Road, travel west on the Midway Beach Access Road $1 \mathrm{~km}(0.62 \mathrm{~km})$ to the beach. Proceed $80 \mathrm{~m}(264 \mathrm{ft})$ south along the crest of the primary dune to the monument. The profile originates $1 \mathrm{~m}(3.28 \mathrm{ft})$ north of the monument.

\section{GELF}

This site is located in the vicinity of North Cove, Washington. To reach the site from the intersection of SR105 and Cranberry Lane / Grayland Beach Road, follow SR105 south $9.17 \mathrm{~km}$ (5.7 miles) to Warrenton Cannery Road. Travel west on Warrenton Cannery Road to the beach access parking area. On the north side of the road is a wood frame restroom. The monument is located approximately $100 \mathrm{~m} \mathrm{(328}$ $\mathrm{ft}$ ) west of the northwest corner of the restroom. The profile begins across the beach access road approximately $30 \mathrm{~m}(98.4 \mathrm{ft})$ south of the monument. 


\section{CSW}

This site is located approximately $100 \mathrm{~m}(328 \mathrm{ft})$ southeast of the SR105 groin that was completed during summer 1998. To reach the site from the intersection of SR105 and Warrenton Cannery Road, follow SR105 south toward Tokeland. The profile is accessible from a path that begins at the turnout located at the southern end of the SR 105 revetment. The profile is located approximately $200 \mathrm{~m}(656 \mathrm{ft})$ northwest of the path/beach intersection.

\section{A.3 Long Beach Sub-cell}

\section{LB-1}

This site is located in the vicinity of Oysterville, Washington. This profile is within the Willapa Bay National Wildlife Refuge at the northern end of Leadbetter Point, and driving motor vehicles on the beach is not permitted. To reach the site from Oysterville, travel west on the Oysterville Road beach access. Continue north on the beach $11.90 \mathrm{~km}$ (7.40 miles). The monument is located approximately $300 \mathrm{~m}(984$ $\mathrm{ft})$ to the east. The profile begins $1 \mathrm{~m}(3.28 \mathrm{ft})$ southwest of the monument.

\section{PC055}

This site is located in the vicinity of Oysterville, Washington. This profile is within the Willapa Bay National Wildlife Refuge, and driving motor vehicles on the beach is not permitted. To reach the site from Oysterville, head west on the Oysterville Road beach access. Continue north on the beach $9.83 \mathrm{~km}$ (6.10 miles) and then east approximately $300 \mathrm{~m}(984 \mathrm{ft})$ to the monument. The profile originates near the monument.

\section{PC051}

This site is located in the vicinity of Oysterville, Washington. This profile is within the Willapa Bay National Wildlife Refuge, and driving motor vehicles on the beach is not permitted. To reach the site from Oysterville, proceed west on the Oysterville Road beach access. Continue north on the beach 7.85 $\mathrm{km}$ (4.88 miles) then east approximately $110 \mathrm{~m}(370 \mathrm{ft})$ to the monument. The profile originates near the monument.

\section{PC044}

This site is located in the vicinity of Oysterville, Washington. To reach the site from Oysterville, travel west on Oysterville Road to G Street. Continue west on the beach access road to the beach. Proceed north on the beach $3.5 \mathrm{~km}(2.17 \mathrm{miles})$. The monument is located approximately $100 \mathrm{~m}(328 \mathrm{ft})$ to the east. The profile originates near the monument.

\section{PC057}

This site is located in the vicinity of Surfside Estates, northwest of Oysterville, Washington. To reach the site from Oysterville, travel west on Oysterville Road to G Street. Continue west on the beach access road to the beach. Proceed north on the beach $1.43 \mathrm{~km}(0.89 \mathrm{miles})$. The monument is located approximately $70 \mathrm{~m}(230 \mathrm{ft})$ to the east. The profile originates near the monument.

\section{OYSTER 3}

This site is located in the vicinity of Oysterville, Washington. To reach the site from Oysterville, travel west on Oysterville Road to G Street. Continue west on the beach access road to the beach. Proceed south on the beach approximately $120 \mathrm{~m}(400 \mathrm{ft})$. The monument is located approximately $50 \mathrm{~m}(164 \mathrm{ft})$ to the east. The profile originates approximately $70 \mathrm{~m}$ south of the monument.

\section{PC037}


This site is located in the vicinity of Ocean Park, Washington. To reach the site from the intersection of SR103 and Bay Avenue, travel west on the Bay Avenue beach access $0.58 \mathrm{~km}(0.36$ miles $)$ to the beach. Continue north on the beach $3.96 \mathrm{~km}$ (2.46 miles). The monument is located approximately $90 \mathrm{~m} \mathrm{(300 \textrm {ft } )}$ to the east. The profile originates near the monument.

\section{PC035}

This site is located in the vicinity of Ocean Park, Washington. To reach the site from the intersection of SR103 and Bay Avenue, travel west on the Bay Avenue beach access $0.58 \mathrm{~km}(0.36$ miles $)$ to the beach. Continue north on the beach $2.75 \mathrm{~km}(1.71 \mathrm{miles})$. The monument is located approximately $90 \mathrm{~m}(300 \mathrm{ft})$ to the east. The profile originates near the monument.

\section{PC032}

This site is located in the vicinity of Ocean Park, Washington. To reach the site from the intersection of SR103 and Bay Avenue, travel west on the Bay Avenue beach access $0.58 \mathrm{~km}(0.36$ miles $)$ to the beach. Continue north on the beach $0.89 \mathrm{~km}(0.55$ miles $)$. The monument is located approximately $90 \mathrm{~m}(300 \mathrm{ft})$ to the east. The profile originates near the monument.

\section{KLIPSAN 2}

This site is located in the vicinity of Ocean Park at Klipsan Beach. To reach the site from the intersection of SR103 and Bay Avenue, travel south on SR 103 for $2.98 \mathrm{~km}$ (1.85 miles). Continue west along the Klipsan Beach access road. The monument is located approximately $100 \mathrm{~m}(328 \mathrm{ft})$ south of the small restroom on the access road. The profile originates near the monument.

\section{PC021}

This site is located in the vicinity of Klipsan Beach, Washington. To reach the site from the intersection of SR103 and Klipsan Road, travel west along the Klipsan Road beach access $0.37 \mathrm{~km}(0.23$ miles $)$ to the beach. Continue south on the beach $2.98 \mathrm{~km}(1.85 \mathrm{miles})$. The monument is located approximately $100 \mathrm{~m}$ (330 ft) to the east on the top of the highest dune. The profile originates near the monument.

\section{$\mathrm{RICH}$}

This site is located in the vicinity of Klipsan Beach, Washington. To reach the site from the intersection of SR103 and Klipsan Road, travel west along the Klipsan Road beach access $0.37 \mathrm{~km}(0.23$ miles) to the beach. Continue south on the beach $5.67 \mathrm{~km}$ (3.52 miles). Proceed east approximately $175 \mathrm{~m}(575 \mathrm{ft})$ to the monument. The profile originates near the monument.

\section{PC014}

This site is located in the vicinity of Long Beach, Washington. To reach the site from the intersection of SR103 and Cranberry Road, follow Cranberry Road beach access west $0.48 \mathrm{~km}(0.3 \mathrm{miles})$ to the beach. Travel south on the beach $1.06 \mathrm{~km}(0.66$ miles $)$. The monument is located approximately $190 \mathrm{~m}(620 \mathrm{ft})$ to the east. The profile originates near the monument.

\section{JACKSON}

This site is located in the vicinity of Long Beach, Washington. To reach the site from the intersection of SR103 and Bolstad, travel $730 \mathrm{~m}$ (2400 ft) west on Bolstad St. to the beach. Continue north on the beach $1.5 \mathrm{~km}(0.9$ miles $)$. The profile begins $120 \mathrm{~m}$ (394 ft) east in the dune. No monument is in the immediate vicinity of this profile site.

\section{PC008}

This site is located in the vicinity of Long Beach, Washington. To reach the site from the intersection of SR103 and $10^{\text {th }}$ Street South in Long Beach, continue west on the $10^{\text {th }}$ Street South beach access road to 
the beach. Travel south on the beach $140 \mathrm{~m}(460 \mathrm{ft})$. The monument is located approximately $90 \mathrm{~m}(300$ $\mathrm{ft}$ ) to the east. The profile originates near the monument.

\section{PC025}

This site is located in the vicinity of Seaview, Washington. To reach the site from the intersection of SR101 and D Street in Seaview, follow D Street west for $0.89 \mathrm{~km}(0.55 \mathrm{miles})$ to the beach. Travel south on the beach for $0.58 \mathrm{~km}(0.36$ miles $)$. The monument is located approximately $90 \mathrm{~m}(300 \mathrm{ft})$ to the east. The profile originates near the monument.

\section{PC004}

This site is located in the vicinity of Seaview, Washington. To reach the site from the intersection of US101 and D Street in Seaview, follow D Street west for $0.89 \mathrm{~km}(0.55 \mathrm{miles})$ to the beach. Travel south

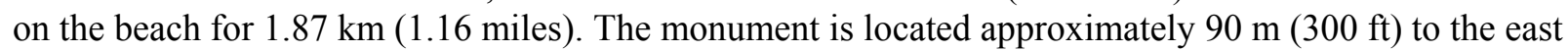
on the top of the highest dune. The profile originates near the monument.

\section{CANBY}

This profile is located within Fort Canby State Park southwest of Ilwaco. To reach the site from the junction of first street south and US101, travel $0.16 \mathrm{~km}(0.1 \mathrm{miles})$ along Spruce Street. Proceed south along $2^{\text {nd }}$ Avenue for $3.6 \mathrm{~km}$ (2.2 miles) to the entrance of Fort Canby State Park. Enter the main park entrance and turn right into the camping area. Stay to the left and follow the road through the camping area to the intersection with a park staff access road. The profile is located approximately $0.40 \mathrm{~km}(0.25$ miles $)$ west on the access road. No monument is in the immediate vicinity of this profile site.

\section{A.4 Clatsop Plains Sub-cell}

\section{EAST JETTY 2}

This site is located $4.83 \mathrm{~km}$ (3.0 miles) northwest of Hammond and is within the Fort Stevens State Park. To reach the site from Hammond, follow signs to the State Park, and once within the State Park, follow signs to the south jetty. On the final access road to the south jetty, travel south on a sand road for $0.16 \mathrm{~km}$ ( 0.1 miles) (access of which is prohibited to motor vehicles). The monument is $2.59 \mathrm{~m}(8.5 \mathrm{ft})$ southwest of a $2.44 \mathrm{~m}(8.0 \mathrm{ft})$ high iron cross set in a concrete base. The profile begins approximately $450 \mathrm{~m}(0.28$ miles) south of the monument.

\section{IREDALE}

This site is located in the vicinity of Warrenton, Oregon, in Fort Stevens State Park. To reach the site from Warrenton, follow US101 Spur to $18^{\text {th }}$ Street SW. Follow $18^{\text {th }}$ Street north to the southern entrance to the State Park. Travel west through the entrance to a flashing red light. Continue west through the camping area to Peter Iredale Road. Follow signs to the Peter Iredale parking areas. Proceed to the southern-most parking area with a wood frame restroom on the north side of the lot. The monument is $28.5 \mathrm{~m}(93.5 \mathrm{ft})$ east of the southeast corner of the cement slab foundation of the restroom. The profile originates approximately $80 \mathrm{~m}(262.5 \mathrm{ft})$ north of the monument and passes the north side of the Peter Iredale shipwreck.

\section{KIM}

This site is located in the vicinity of Warrenton, Oregon, at the northern boundary of Camp Rilea National Guard Base. To reach the site from Warrenton High School, travel west on South Main Street / US101 Spur to $18^{\text {th }}$ Street. Continue north on $18^{\text {th }}$ Street $2.81 \mathrm{~km}$ (1.75 miles) to a "Y" intersection. Proceed west across Ridge Road to Delaura Beach Road SW. The profile begins just south of the intersection of the 
gravel portion of Delaura Beach Road SW and the beach. There is no monument in the immediate vicinity of this profile.

\section{RILEA}

This site is located in the vicinity of Gearhart, Oregon at the southern end of the Camp Rilea National Guard Base. To reach the site from US101/26, proceed west on Sunset Beach Road to the beach. Continue north on the beach $1.75 \mathrm{~km}$ (1.09 miles). Travel east to the top of the dune and the lone telephone pole. The monument is approximately $20 \mathrm{~m}(66 \mathrm{ft})$ southeast of the pole. The profile begins near the monument.

\section{DELRAY}

This site is located in the vicinity of Gearhart, Oregon. To reach the site from the intersection of US101/26 and Pacific Way in Gearhart, travel north $2.82 \mathrm{~km}$ (1.75 miles) on US101/26 to Highlands Road. Continue west on Highlands Road to the Delray Beach Access parking area. The monument associated with this site is located $68 \mathrm{~m}(223 \mathrm{ft})$ southwest of the southern corner of a park information sign. The sign is located at the "Y" intersection of the beach access road and the parking lot road. The profile originates approximately $150 \mathrm{~m}(490 \mathrm{ft})$ north of the monument in the dunes north of the beach access road.

\section{SEASIDE RM 2}

This site is located in the City of Seaside, Oregon. To reach the site from the western end of $12^{\text {th }}$ Avenue in Seaside, travel approximately 100 meters $(330 \mathrm{ft})$ north of the public restroom. The seaward end of the profile is south of the mouth of the Necanicum River. There is no monument in the immediate vicinity of this profile. 